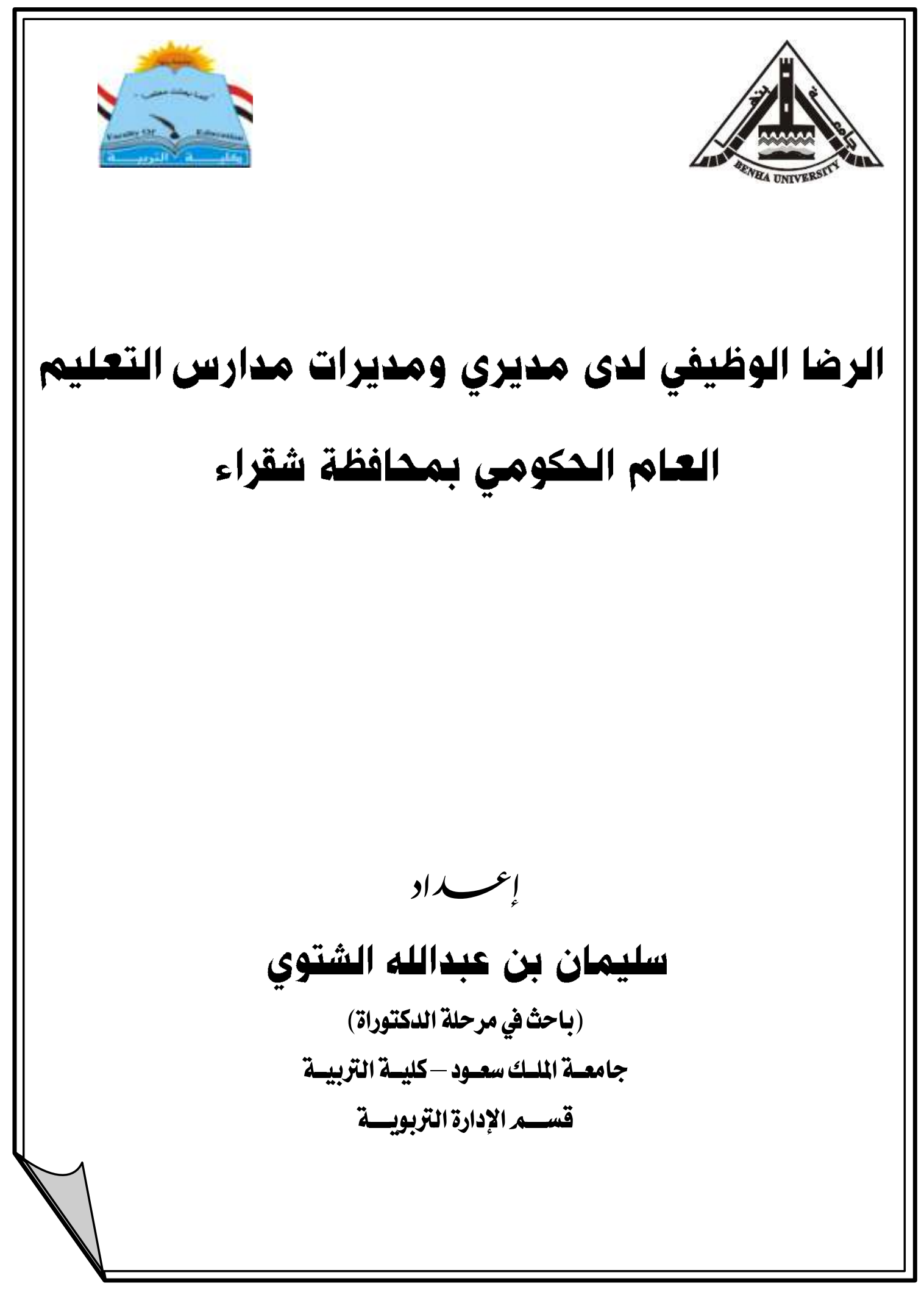




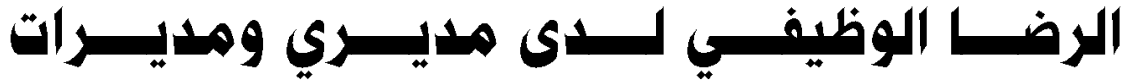

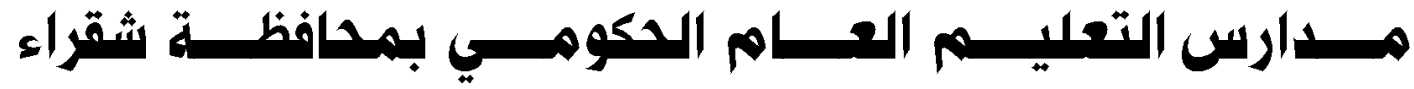<smiles>[AlH2]C[Tl]</smiles>

سليمان بن عبدالله الشتوي

(باحث في مرحلة الدكتوراة)

جامعـة الملـك سعـود -كليـة التربيـة

قســـــــالإدارة التزبويـــة

المقدمهـــة:

تعد المدرسة إحدى المؤسسات الاجثماعية التي تسهم مع غيرها من المؤسسات فـي ثربية الإنسان ومساعدثه على نمو شخصيته المنكاملة وفقا لقدراته وميوله و استعداداثه ولكي تؤدي المدرسة وظيفتها التربوية خير أداء فإنها تحناج إلى إمكانات مادية وبشرية وتحتاج إلى إدارة تثولى القيام بمجموعة عمليات موجهه لتحقيق الأهداف المنشودة ويعـد مسـدير الإدارة

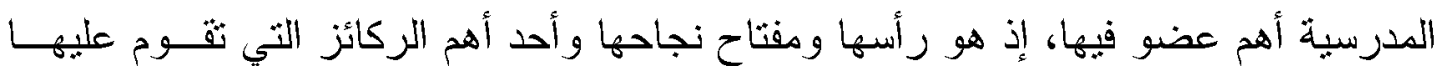
العملية التعليمية و الثربوية، و على ذلك فإن الاهنمام به بساهم في تحقيق المجثمـع لأهدافــه،

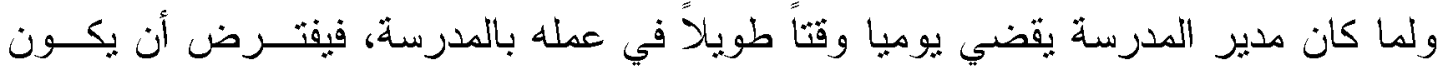
راضياً عن العمل الذي يؤديه. فبقدر ما يكون الإنسان راضياً عن عمله بقر ما يكون راضياً عن حباته و العكس صحيح.

حيث أكدث دراسة روي على أنه من الصعب أو ربما يكون من المستحيل الفصــلـ

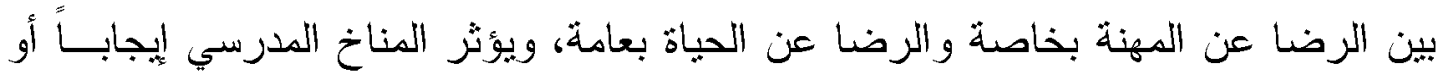

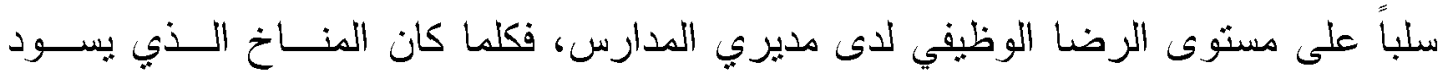
المدرسة قائماً على أساس من التعاون والعلاقات الإنسانية الجيدة بين أفر اد الإدارة المدرسية، كان مسثوى الرضا الوظيفي مرتفعاً، وهذا يسهل سير العمل، ويؤدي إلى تحسين أداء الإدارة

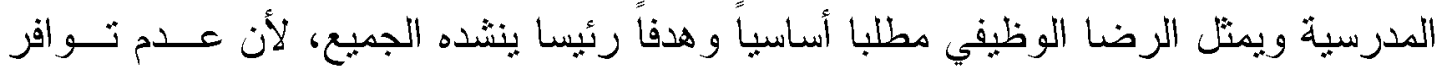
الحد الأدنى من الرضا لدى القرد، لا سيما في مجال التعليم قد يكون له انعكاســات خطيــرة على مستوى العملية التعليمية بشكل عام، ومخرجاتها على وجه الخصوص، خاصة إذا مـــا 


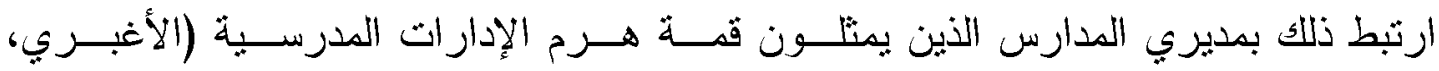

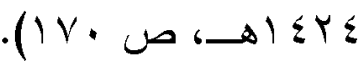

ويشكل الرضا الوظيفي لمدير المدرسة مســالة مهيــة، إذ إن إحساســه بضـــامة

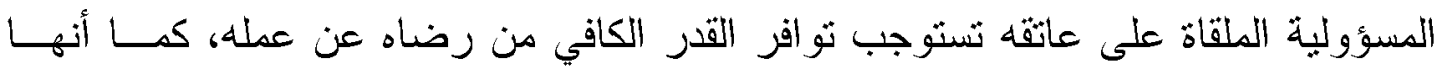
تعكس مدى عطائه للقيام بهذه المسؤولية، ومدى استعداده لبذل المزيد من الجهذ في تحسـين

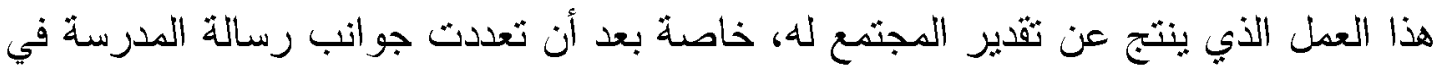

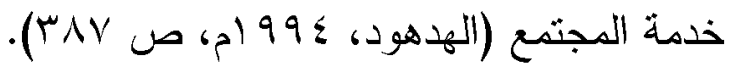

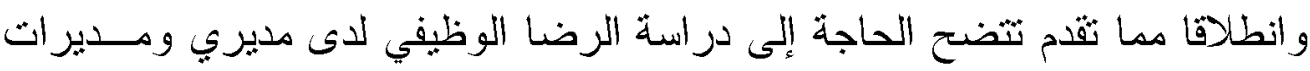

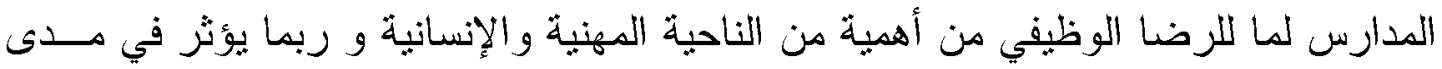
الكفاءة في العمل والارثباط به والحرص عليه.

\section{مشكاسة الدراسـالة:}

الإدارة المدرسية الناجحة يمكن وصفها بأنها حجر زاوية في العملية التعليمية التربويــة

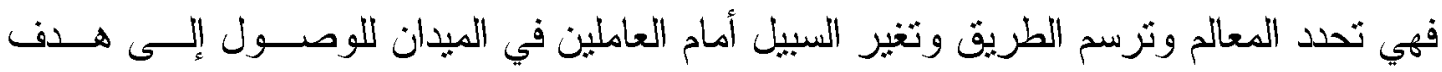

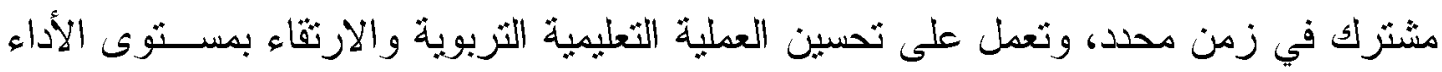

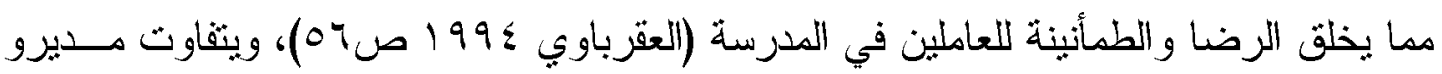
ومديرات المدارس في مستوى رضاهم الوظيفي عن مهنة التعليم، حيث إن مستوى الرضا عنــد فئس

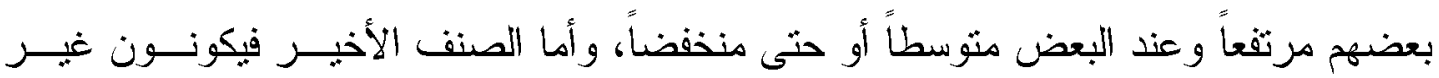
راضين عن مهنة التعليم، فتر اهم كثيرو الثنكوى ومنذمرين من مهنتهم، فالمديرون الذين هم غير

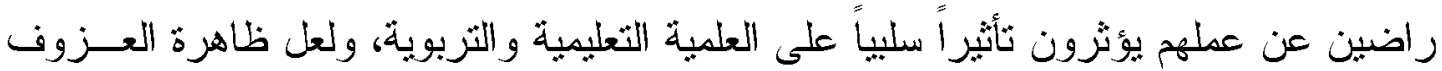
عن التزشح لوظيفة مدير المدرسة بين العاملين في المؤسسات التعليمبة دلبل على وجود مثكلات

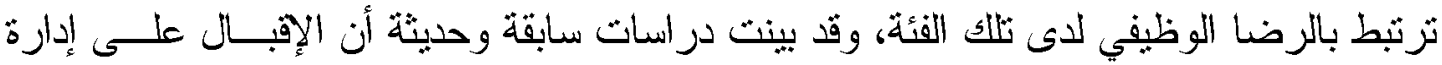

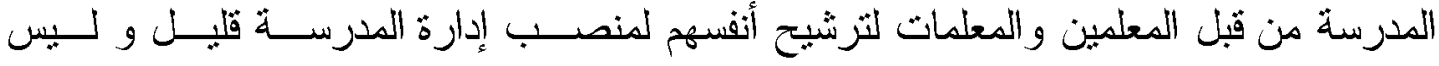

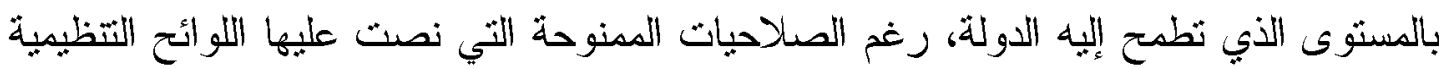

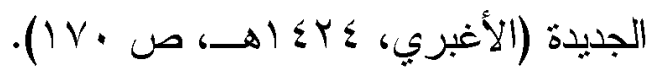

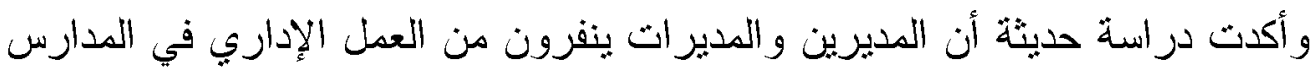

ويحاولون التحويل إلى التدريس مما يوحي بوجود مشكلة حادة بدركها المديرون (العثيبـي، الإدي، 


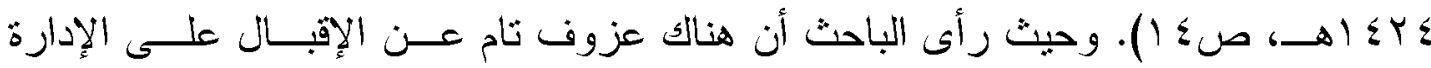

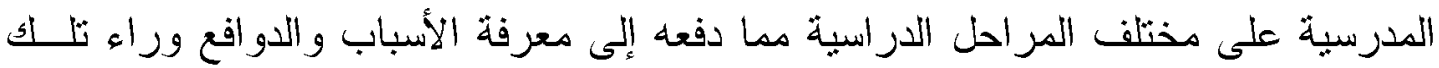

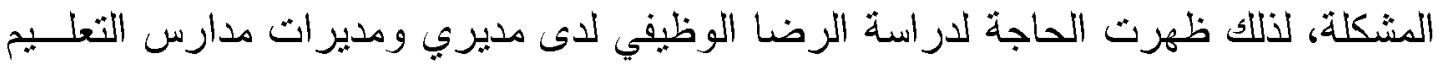
الحكومي الثابعة لإدارة التعليم في محافظة شُقراء.

\section{أهسطداف الدراسيسة:}

تسعى هذه الدراسة إلى تحقيق الأهداف التالية: 1- الثعرف على درجة الرضا الوظيفي لدى مديري ومديرات مدارس التعليم العام الحكومي التهي التابعة لوزارة التربية و النعليم في محافظة شقراء.

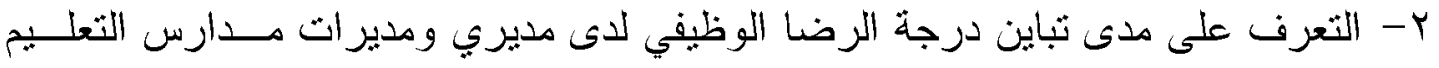
العام الحكومي في محافظة شقر اء.

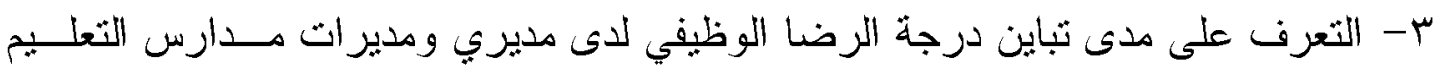
العام الحكومي في محافظة شقر اء باختلاف المرحلة النعليمبة.

\section{أهميسيسة الدراسيسة:}

تثمثل أهمية الاراسة الحالية فيما يلي:

1- تتبع أهية الدراسة من أهمية مدير المدرسة ودوره الكبير في نجاح العملية التعليمة.

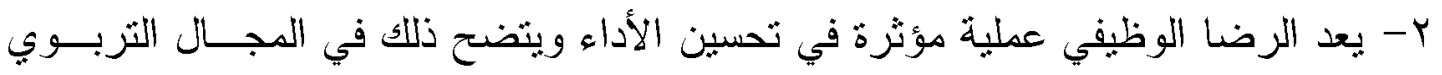

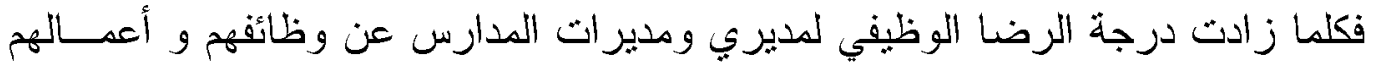
انعكس ذلك إيجابا على العملية التربوية بأكملها.

\section{تسعى هذه الاراسة إلى الإجابة عن الأسئلة التالية:} 1- ما درجة الرضا الوظيفي لدى مديري ومديرات مدارس التعليم العام الحكومي الثابعــة التهابه

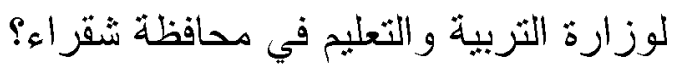
ب- هل تثباين درجة الرضا الوظيفي لاى مديري ومديرات مدارس التعليم العام الحكــومي في محافظة شقر اء؟ r- هل تثباين درجة الرضا الوظيفي لاى مديرب ومديرات مدارس التعليم العام الحكــومي

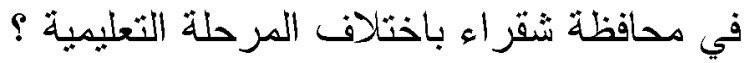




\section{حسدود الدراســة \\ الحدود الموضوعية:}

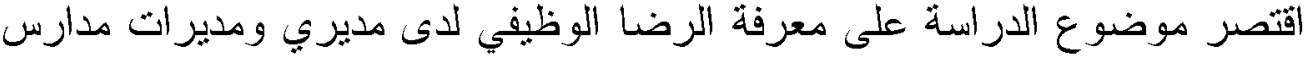

التعليم العام الحكومي بمر احلها الثلاث التابعة لإدارة التربية والتعليم بمحافظة شقراء.

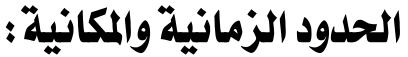

اقتصرت هذه الدر اسة على مديري ومديرات مدارس النعليم العام الحكومي بمراحلها

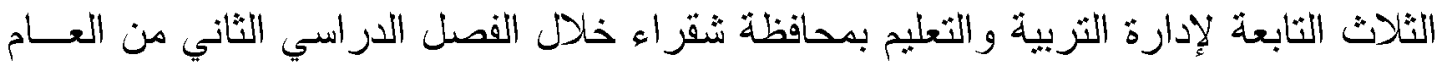

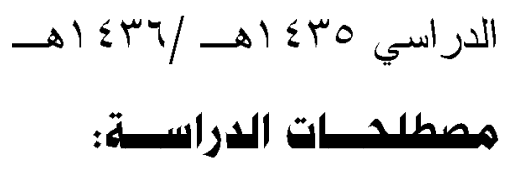

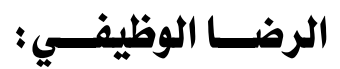

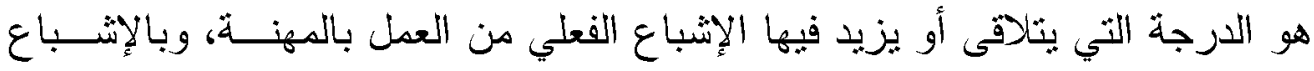

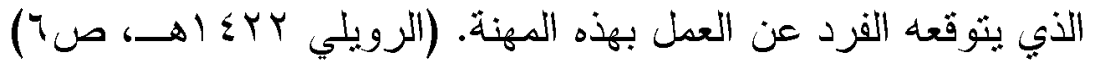

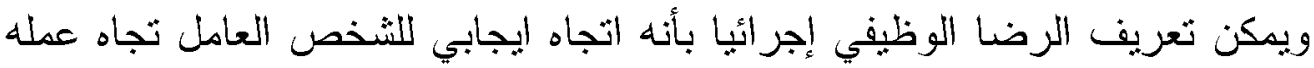

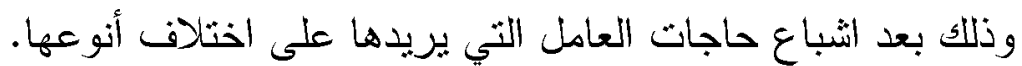

\section{مدير المدرسة / مديرة المدرسة}

هو قائد إداري ونزبوي وهو المسؤول الأول عن سير العمل في المدرسة من جميع

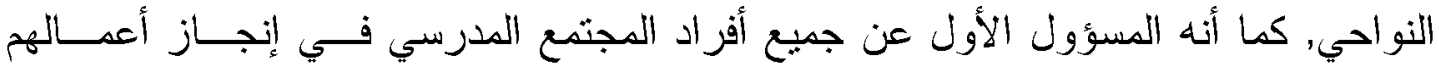

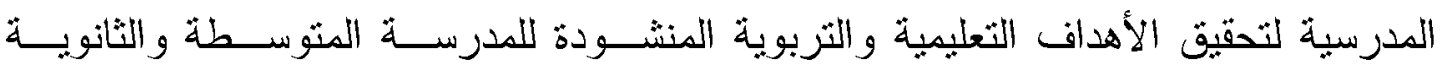

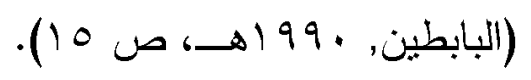

محافظة شقراء:

تقع محافظة شقر اء في المنطقة الوسطى من المملكة العربية السعودية وهـي تابعــة

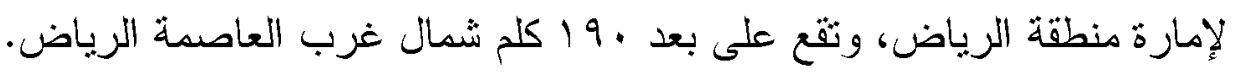

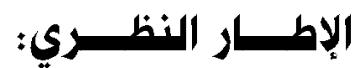

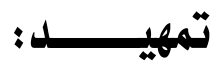

الهتمام الإدارة بالرضا الوظيفي للأفراد بعد من الاتجاهات الحديثة في مجــال إدارة

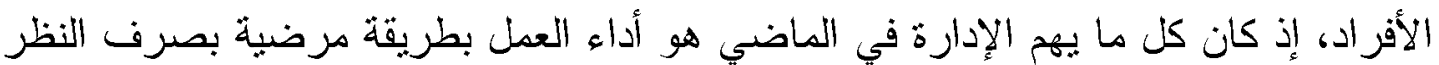




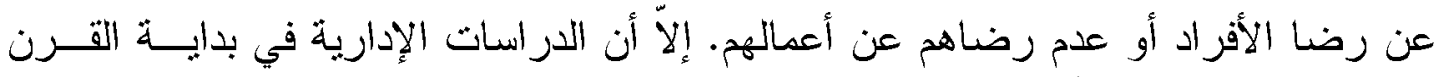

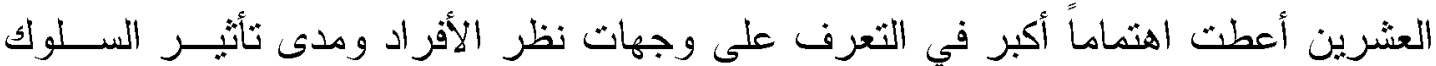

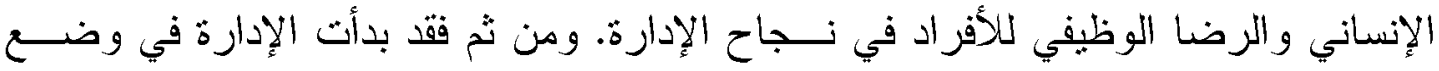

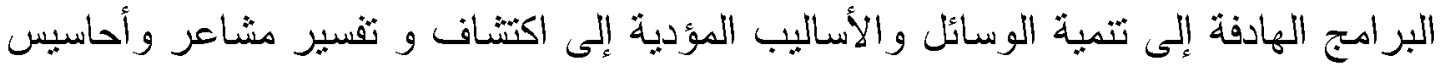

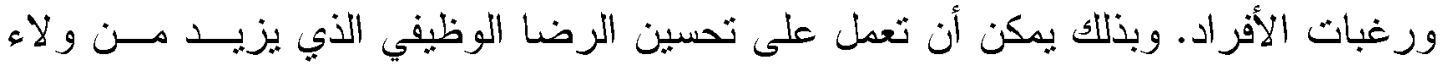
الأفراد تجاه عطلهم، مما يؤثر بالتالي على كفايته في العمل.

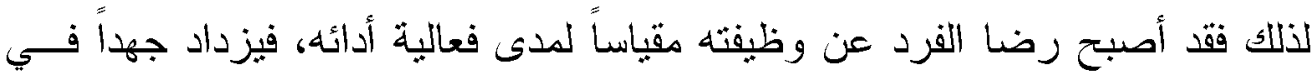
عمله بمقار ما يوفره العمل له من إثباع لحاجاته ودو افعها و استغلال لقدر اتها.

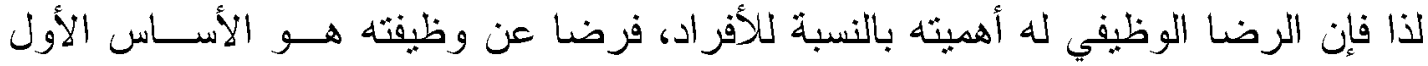

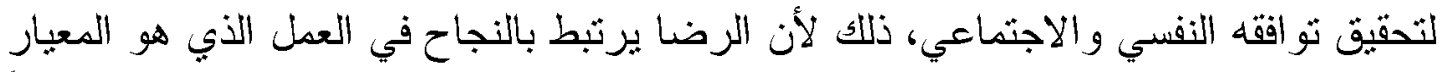

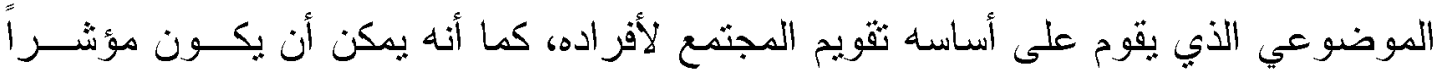

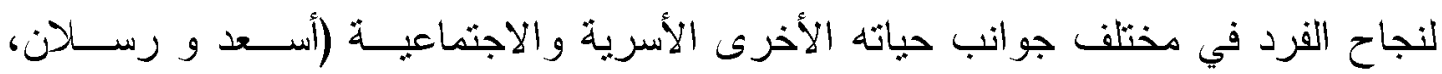

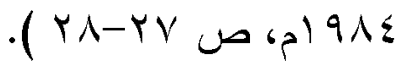

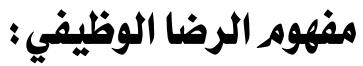

\section{1- المفهوم اللغوي اللرضا:}

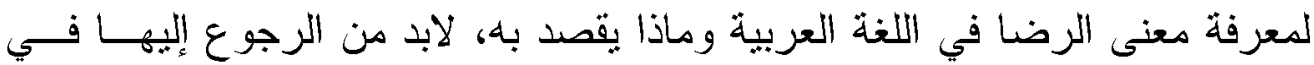

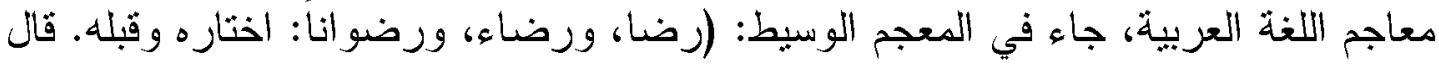

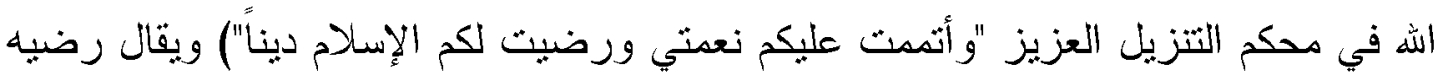

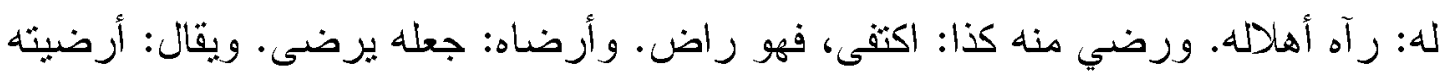

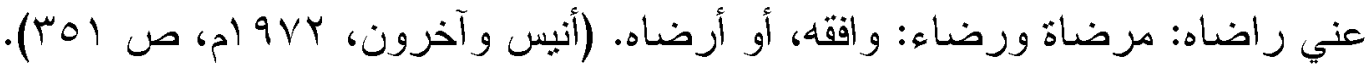

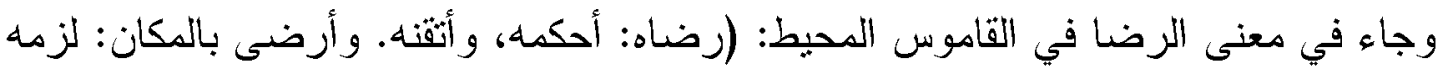

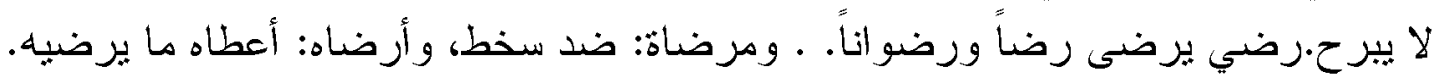

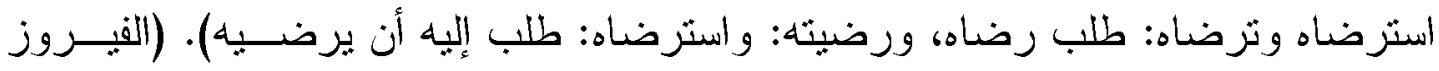

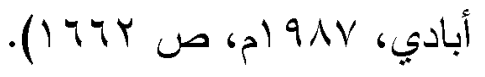

\section{r- l المفهوم الاصطلاهي للرضا:}

الرضا يختلف من شخص إلى آخر ، وعلى هذا فمن الطبيعي أن بختلف الباحثّن في

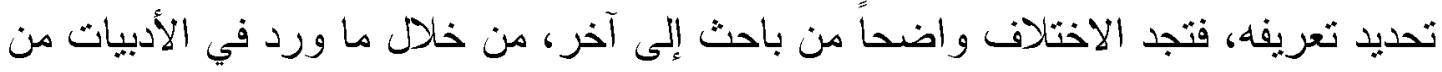
نعاريف، وقد عرف الباحثون الرضا الوظيفي عدة تعاريف نذكر بعضها: 


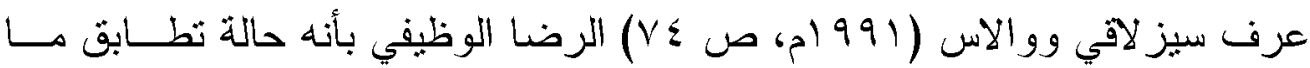

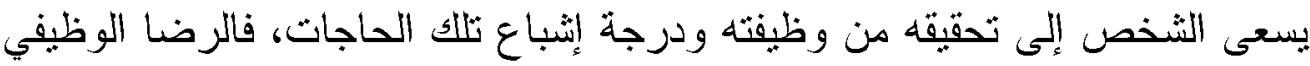

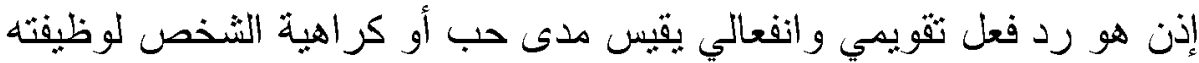

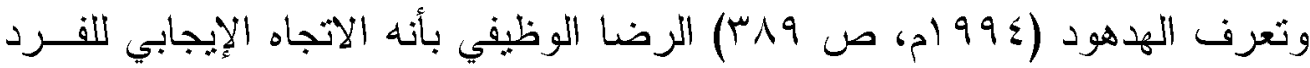

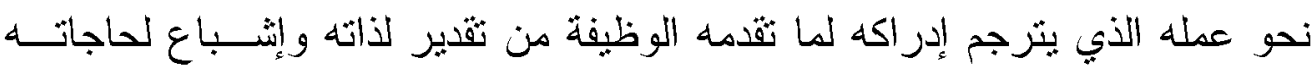

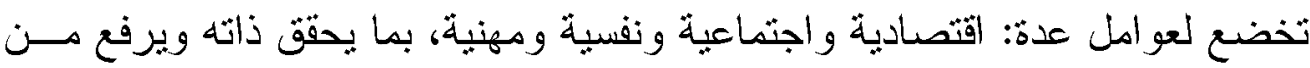

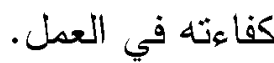

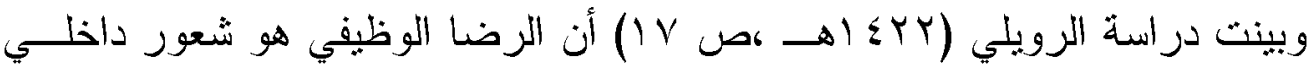

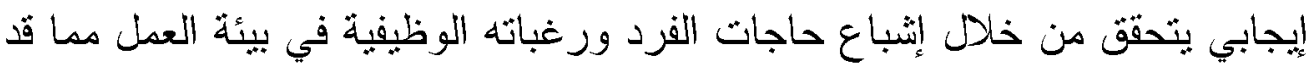
يؤدي إلى تحسين الأداء ورفع الإنتاجية.

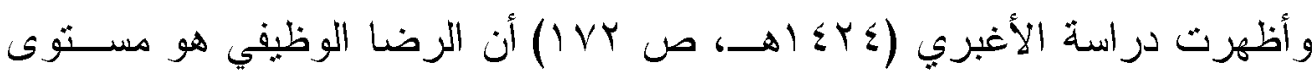

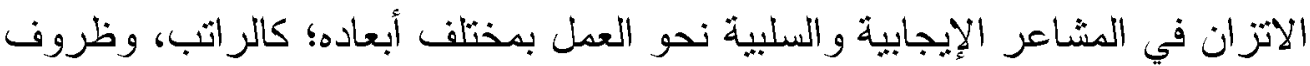

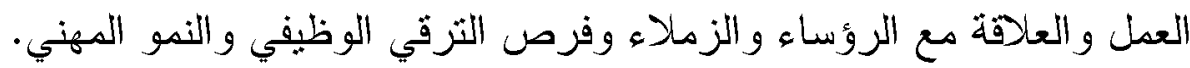

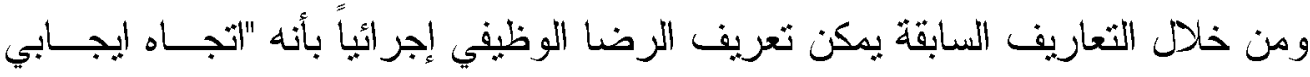
للثخص العامل تجاه عمله وذلك بعد اثباع حاجات العامل الثي يريدها على اختلاف أنوعها".

\section{أنواع الرضا الوظيفي Job Satisfaction Types}

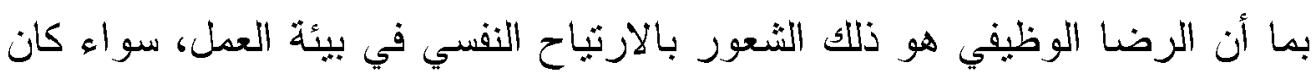

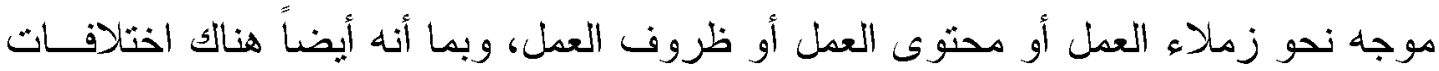

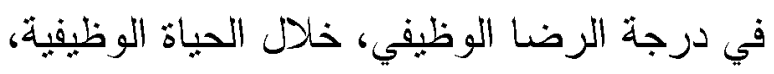

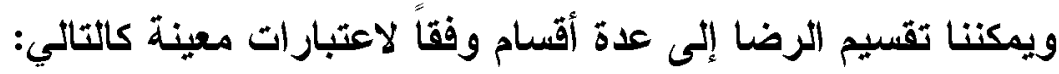

\section{1. أنـواع الرضا الوظيفيب باعتبار شموليته:}

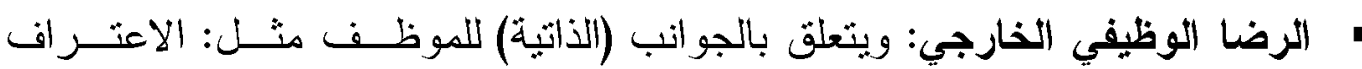

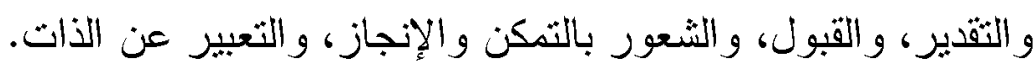
الرضا الوظيفي الخارجي: ويتعلق بالجوانب الخارجية (الييئية) للموظف في محسبط وليط العمل مثل: المدير، وزملاء العمل، ومميزات العمل المالية، وطبيعة ونمط العمل.

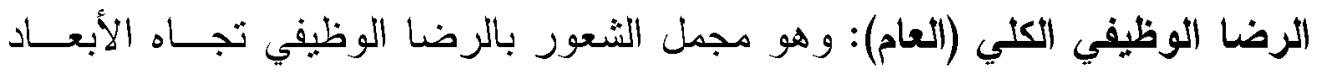

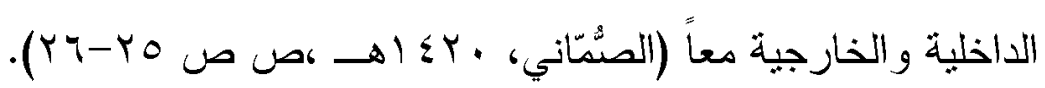




\section{ث. أنواع الرضا الوظيفي باعتبار زمنه:}

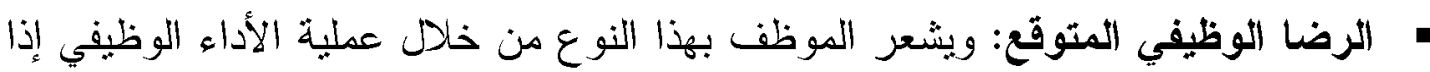

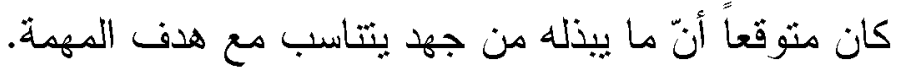
" الرضا الوظيفي الفعلي: ينُعر الموظف بهذا النوع من الرضا بعد مرحلة الرضا الوظيفي

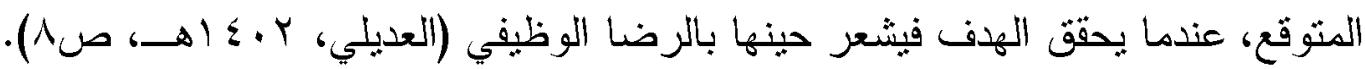

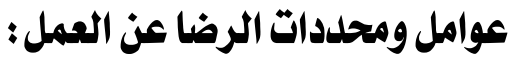

إذا كان الرضـا عن العمل هو نتيجة لمجموعة من العوامل التي تسهم فــي تحقبـق

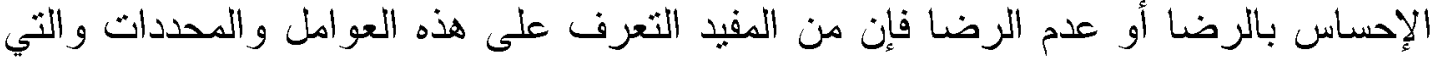

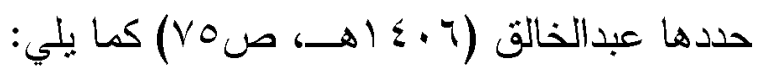
1- عو امل ذاتية تتعلق بقدرات ومؤهلات ومهار ات العاملين. r- عوامل تتظيمية تتعلق بسياسة التعليم وظروف وشروط العدل. r- عوامل بيئية تنعلق بالظروف الييئية المؤثرة على العمل و العامل.

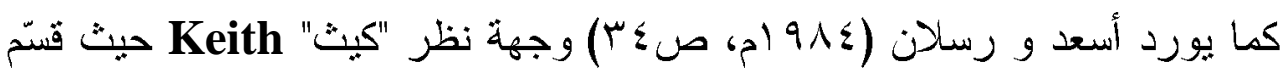

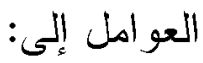

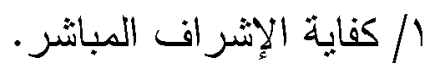
r/ الرضا عن العمل نفسه.

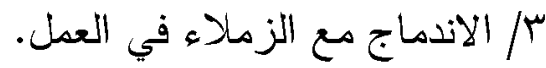

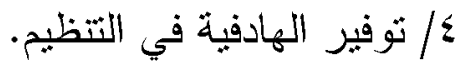
/ / / ع الة المكافآت الاقتصادية. / / الحالة الصحية البدنبة و الذهنية. و هناك مجموعة من العو امل المحبطة بالعمل والني ترثبط ارثباطاً وثيقاً بييئة العمل و ونها:

$$
\text { - - القيادة. }
$$

- اللو ائح والأنظمة المعبرة عن فلسفة المنظمة.

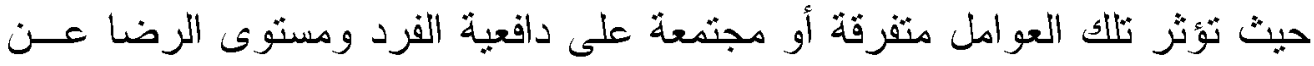

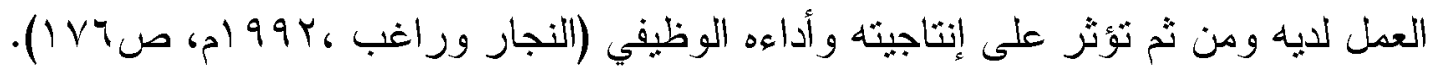


أما بالنسبة لمحددات الرضا عن العمل عند المعلمين فيرى "فــان ديرســال" ( Van

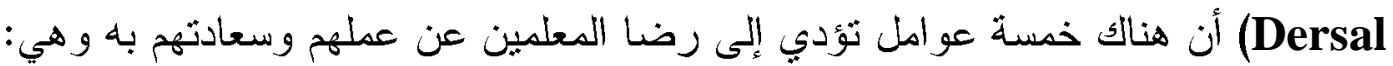

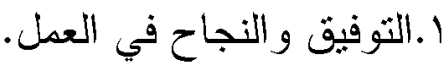
r. حسن الثقدير من الآخرين وبخاصة الرؤساء. r. استهو اء العمل نفسه. ع. تحمل المسئولية وإثبات الجدارة في هذا النحمل.

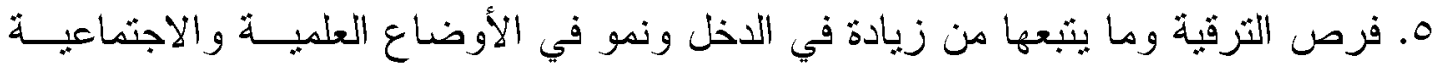

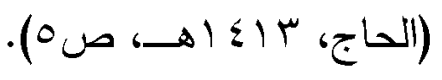

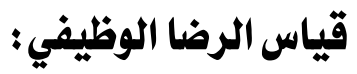

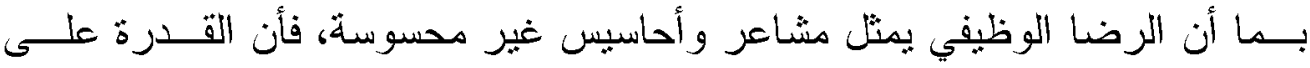

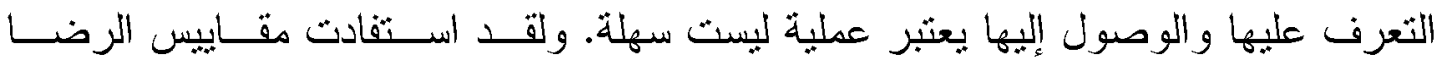

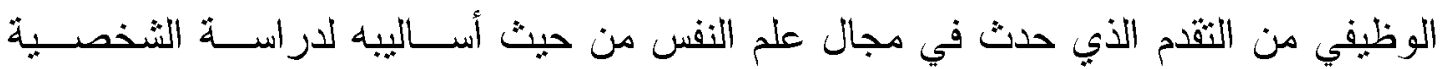

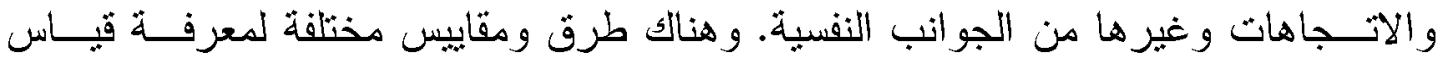

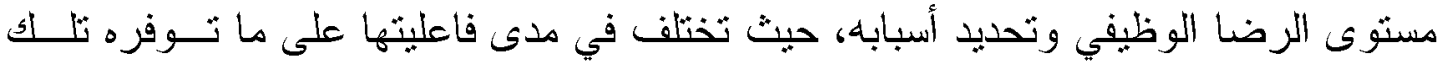
المقاييس من الاقة و الصدق و الثمول بالنسبة لليبانات.

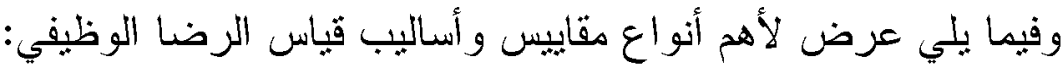

\section{أولاً: أنواع مقاييسر الرضا الوظيفيي:}

هناك نوعان من مقاييس الرضا الوظيفي، وهما:

$$
\text { (أ) المقاييس الموضوعية: }
$$

هذا النوع يقيس الرضا من خلال الآثار السلوكية له، مثل الغياب ونرك الخدمة. وهذا

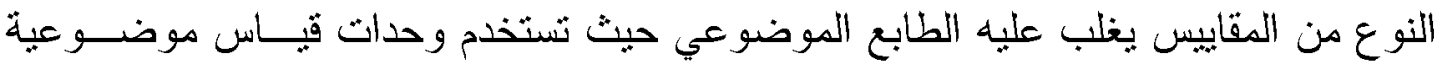

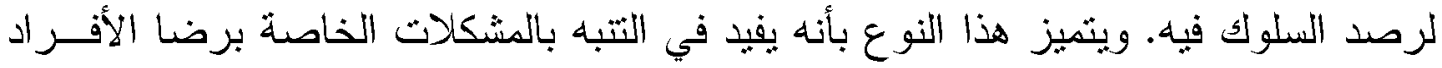

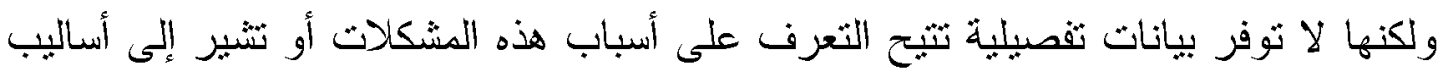

$$
\text { العلاج الممكنة. }
$$

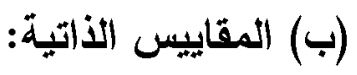

ويقيس هذا النوع الرضا مبانشرة لكن بأساليب تقديرية ذاتية، وذلك بسؤال الأفراد عن مشاعر هم تجاه الجو انب المختلفة للعمل، أو عن مدى ما يوفره العمل من إثباع لحاجاتهم. 


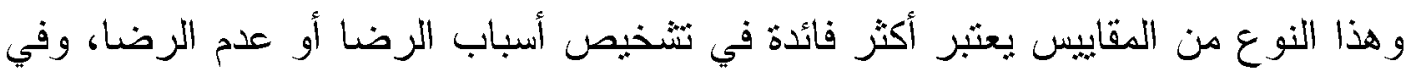

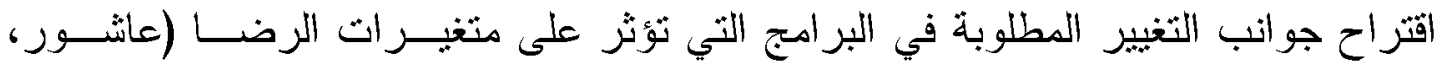

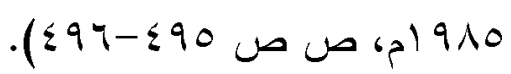

\section{الدراسات المتعلقة بالرضا الوظيفي في الميادين الإدارية التربوية:}

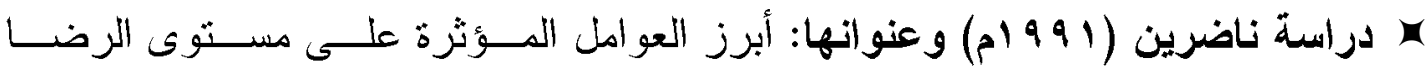

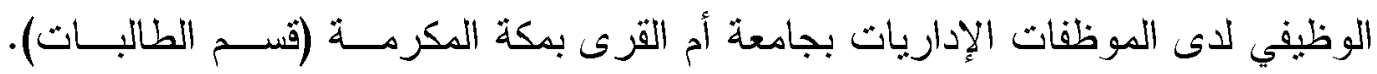

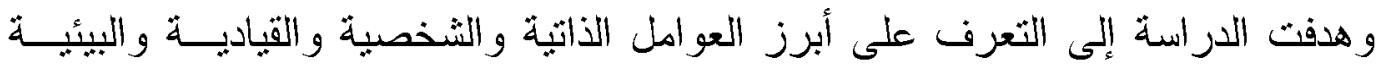

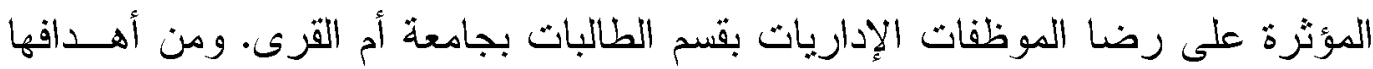

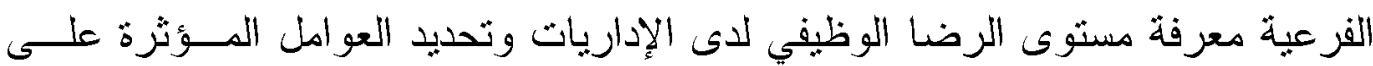

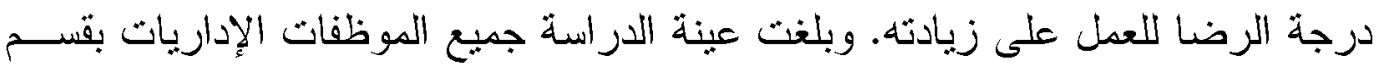

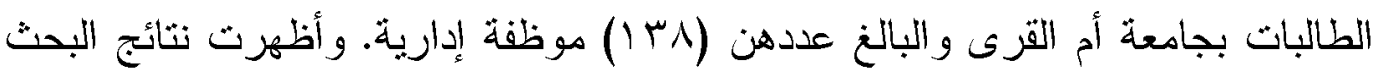

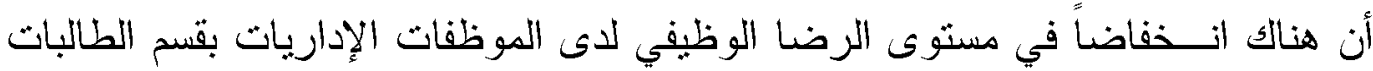

$$
\text { بـامعة أم القرى. }
$$

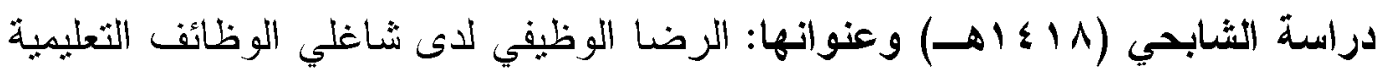

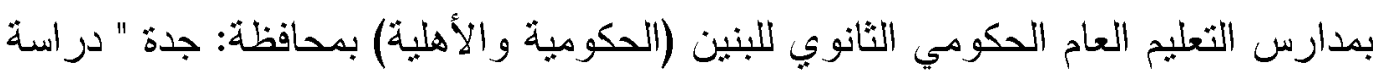

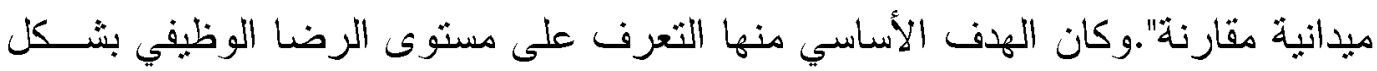

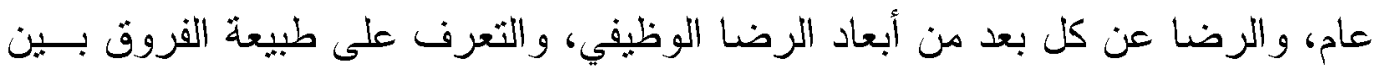

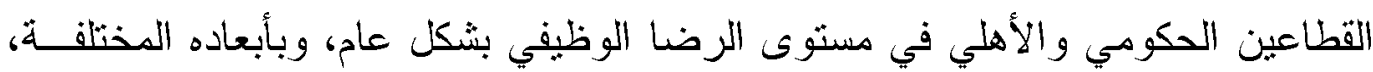

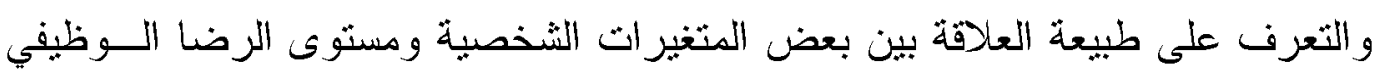

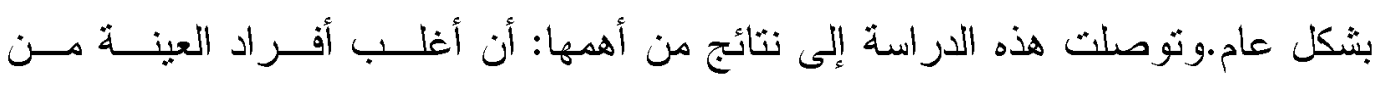

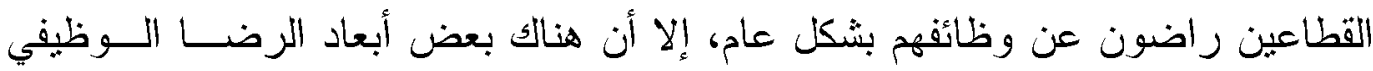

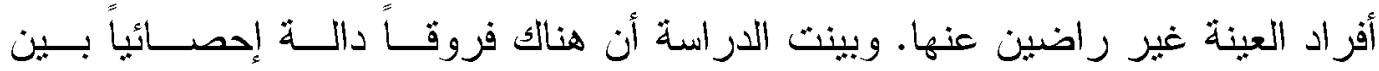
القطاعين في مستوى درجة الرضا الوظيفي بشكل عام، وكذللك الرضا عن كل بعد مــن أبعاد الرضا الوظيفي ما عدا بعض الأبعاد.

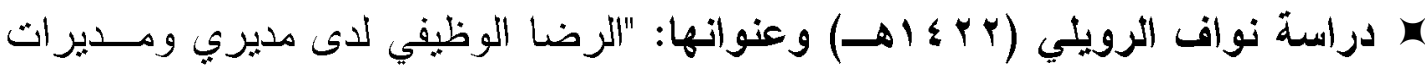

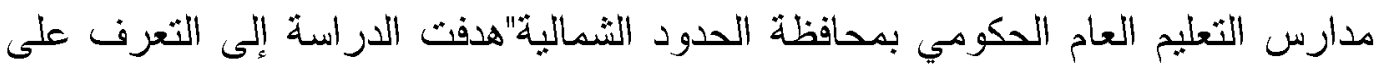
درجة الرضا الوظيفي لاى مديري ومديرات مدارس التعليم العام الحكومي التابعة لوزارة 
المعارف و الرئاسة العامة لنعليم البنات بمحافظة الحدود الثمالية، وكذلك التعرف على

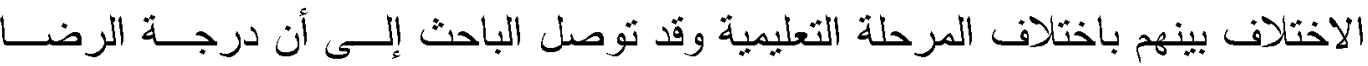

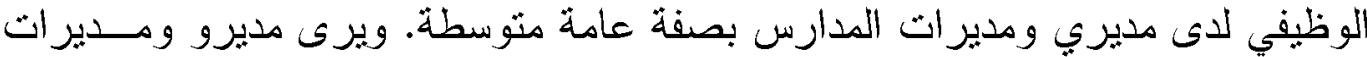

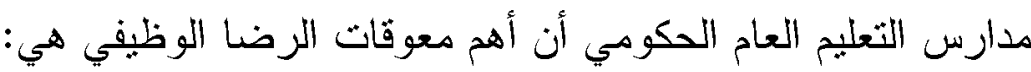

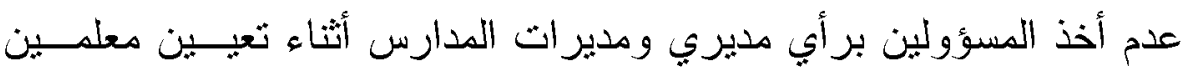

$$
\text { |معلمات جدد في المدرسة. }
$$

• عدم ثوفر المنطلبات المادية اللازمة في العمل. المكافآت المادية والامثيازات

$$
\text { المرتبطة بالعمل. عدم العدالة في استحقاقيه منح الترقية. }
$$

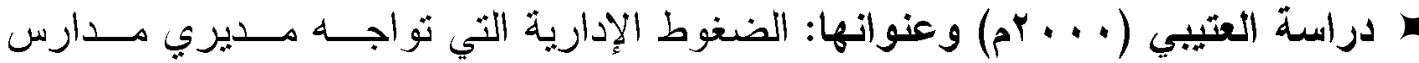
التعليم العام الحكومي وتأثير ها على أدائهم من وجهة نظر هم بمحافظة مكــة المكرهـــة.

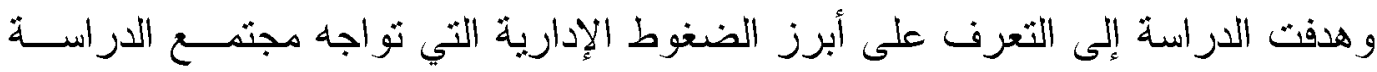

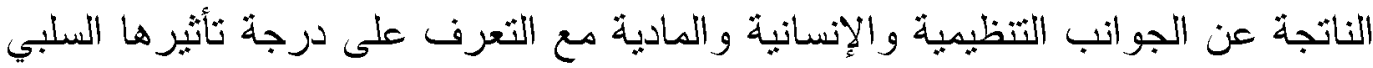

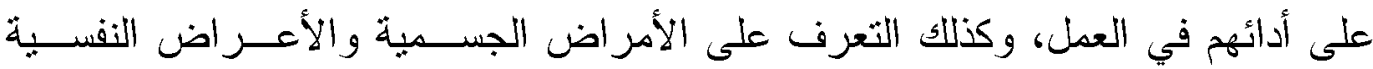

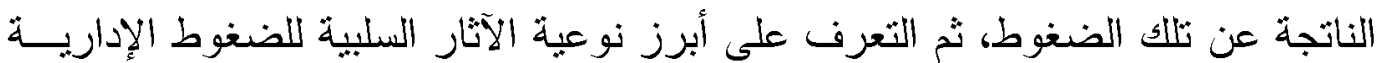
التي تو اجه مجتمع الدراسة على أدائهم في العمل الإداري.

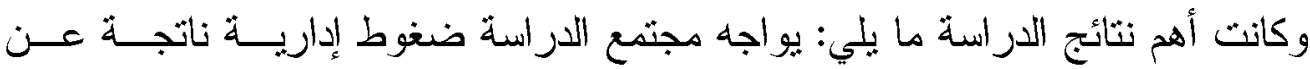

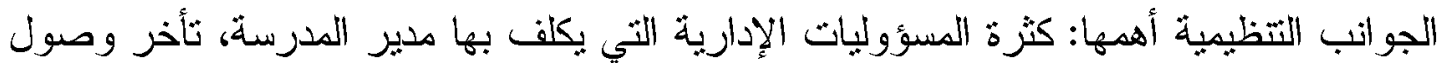

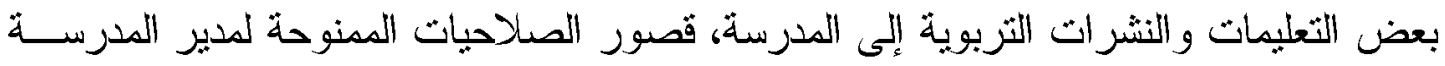

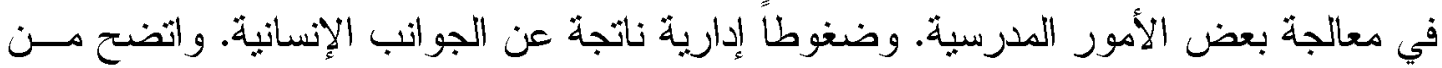

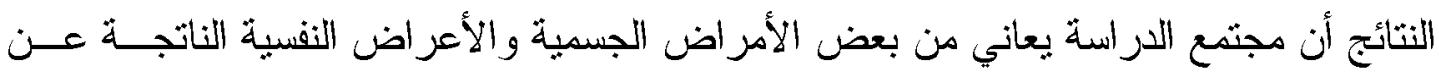

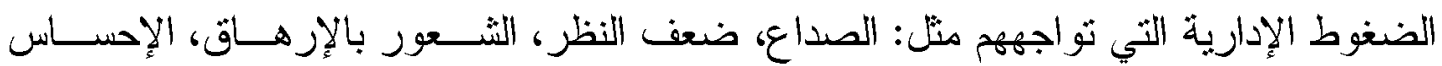

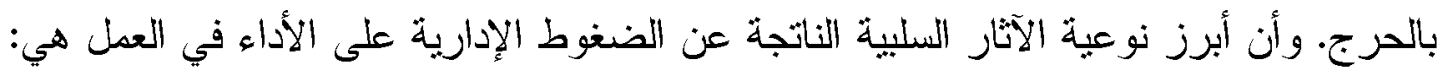

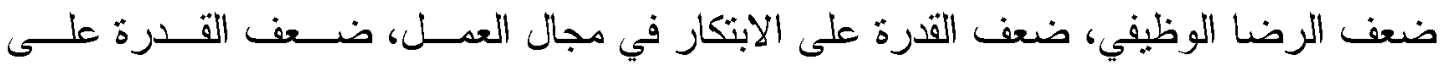

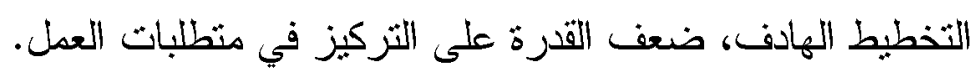

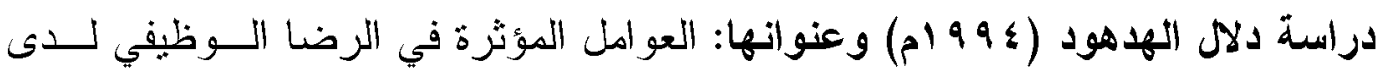

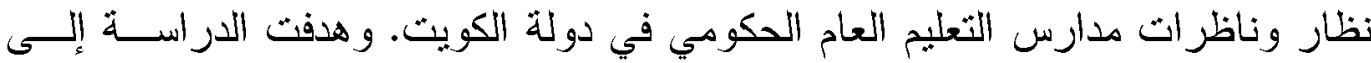

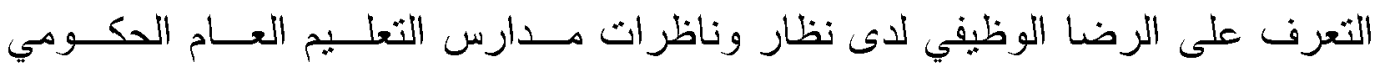

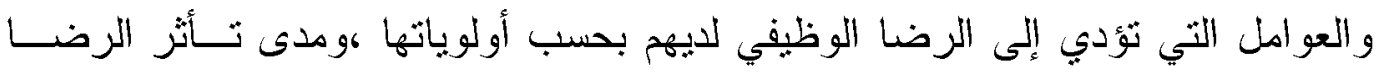


الوظيفي بمتغيرات الدراسة (الجنس - المرحلة - المحافظة التعليمية - العمر - الخبرة

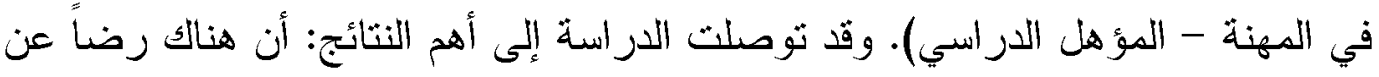

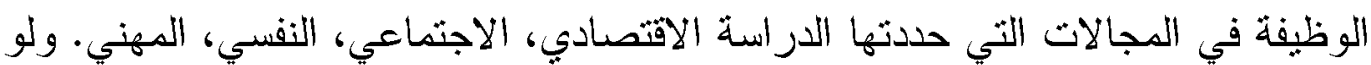

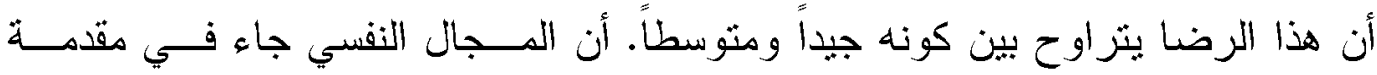

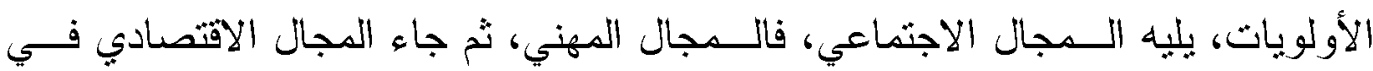

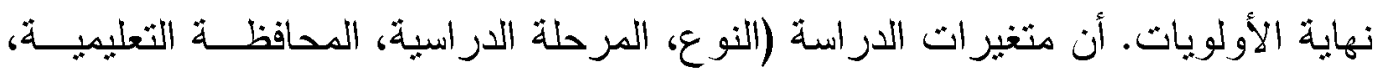

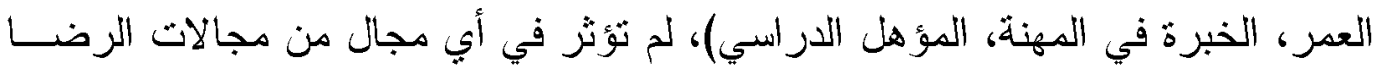

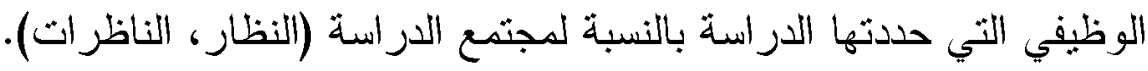

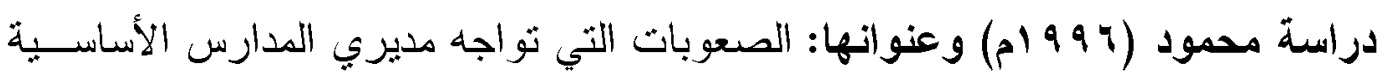

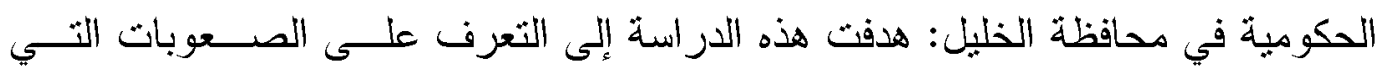

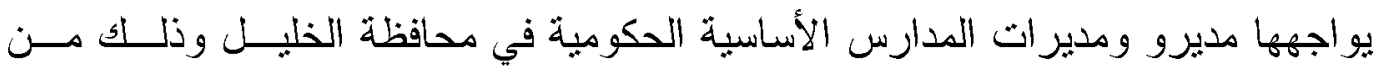

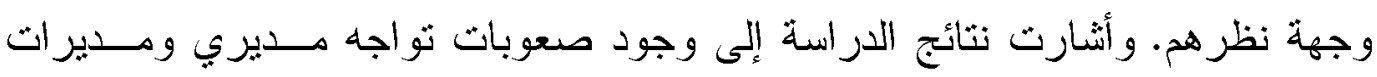

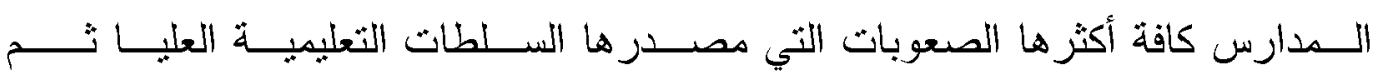

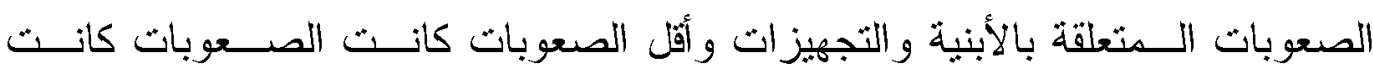
الصعوبات الـــتعلقة بالطلبة.

كما أشنارث النتائج إلى أنه توجد فروق في درجة الصعوبات التي تواجه دديري

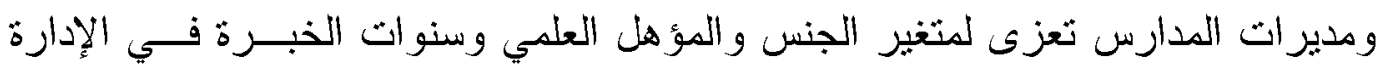
المدرسية وموقع المدرسة.

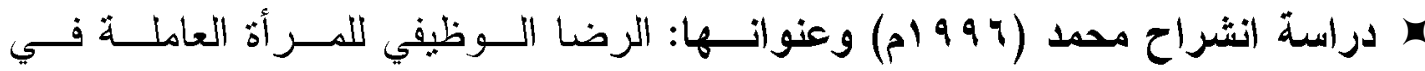

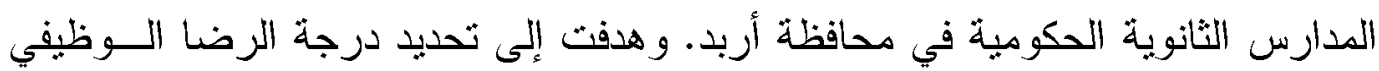

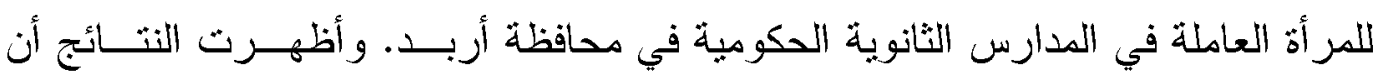

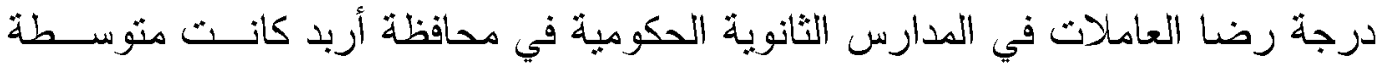

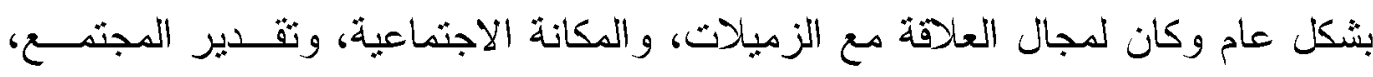

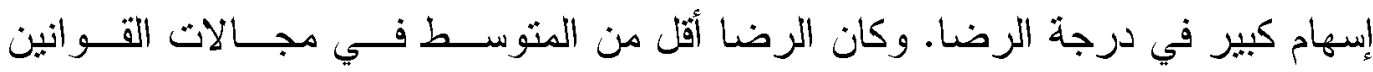

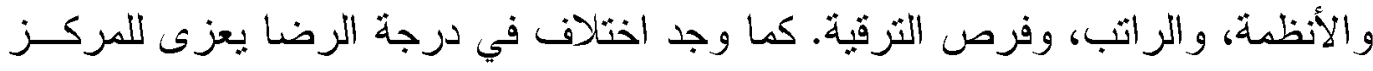

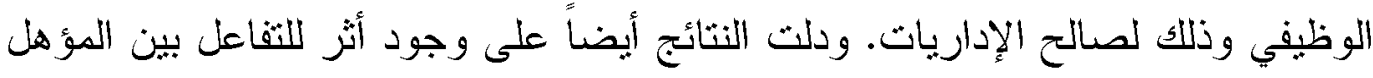

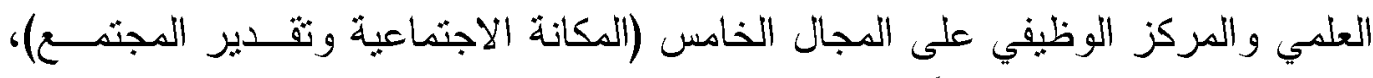
وذلك لصالح الإداريات أيضاً. 
جـ دراسة سليمان (999 (9) و وعنو انها: معوقات العمل في الإدارة المدرسية من وجهة نظر

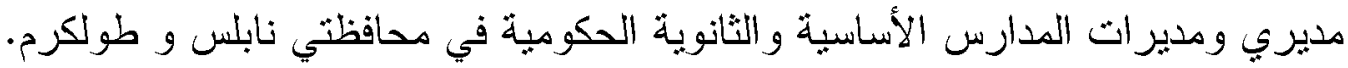
هدفت هذه الدراسة إلى التعرف على معوقات العمل في الإدارة المدرسية من وجهة

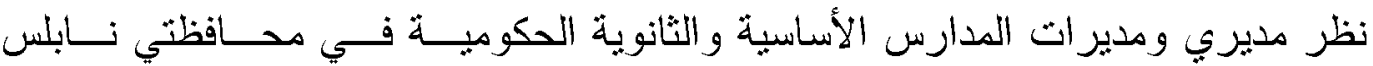

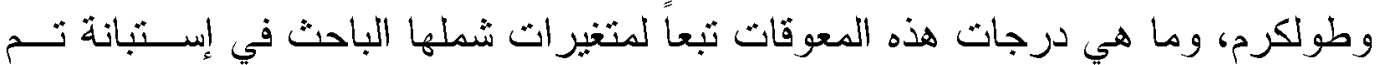

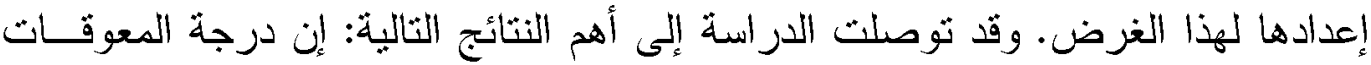

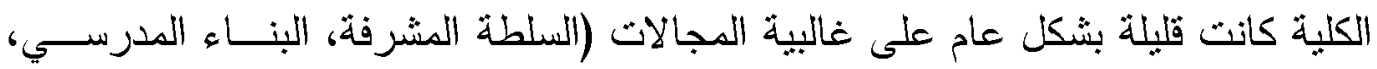

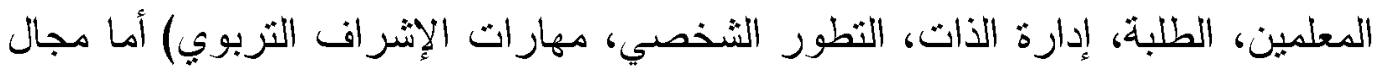
أولياء الأمور فقد كانت درجة المعوقات الكلية عليه منوسطة. إن درجة الصعوبات الكلية

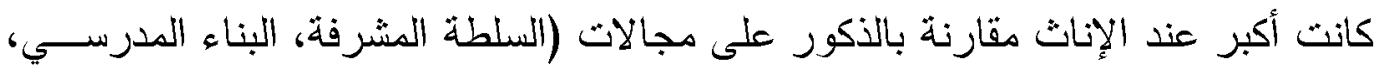

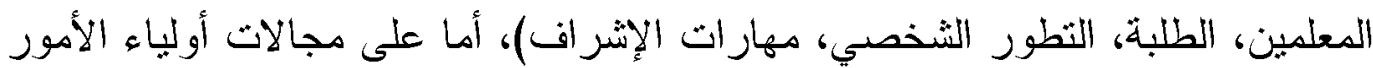
وإدارة الذات فقد كانت درجة الصعوبات أكبر عند الذكور منها عند الإناث.

\section{منهجية الدراسة وإجراءاتهـ:}

يتتاول هذا الفصل إيضاحاً لمنهج الدراسة الذبي اتبعه الباحث، وكذلك تحديد مجنمــع

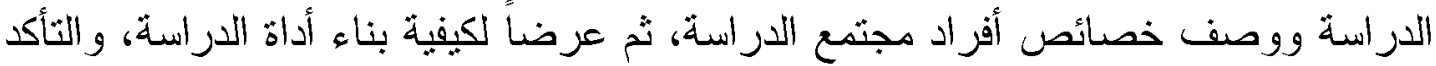
من صدق وثثات أداة الدراسة (الاسثبانة)، والكيفية الثي طبقت بها الدراسة الميدانبة، وأساليب المعالجة الإحصائية الني استخدمت في تحليل البيانات الإحصائية.

\section{منهــــج الدراســة :}

اتبع الباحث في هذه الدراسة المنهج الوصفي الذي يقصد به ذلك النوع من البحسـوث

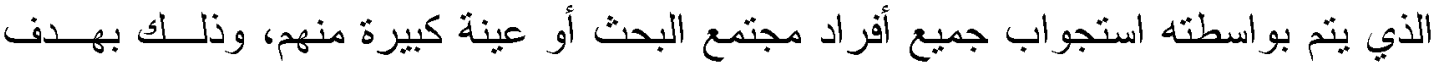

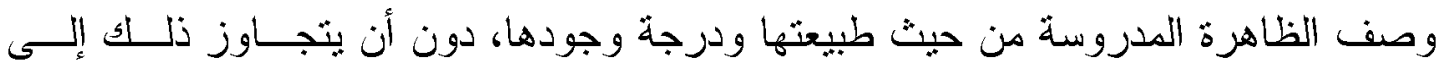

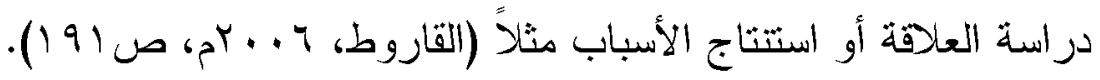

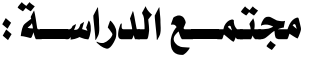

ينكون مجتمع الدراسة من جميع مديري ومديرات مدارس التعليم العام الحكومي في محافظة شقراء في المملكة العربية السعودية، و البالغ عددهم (VV) مديراً ومديرة، في الفصل 


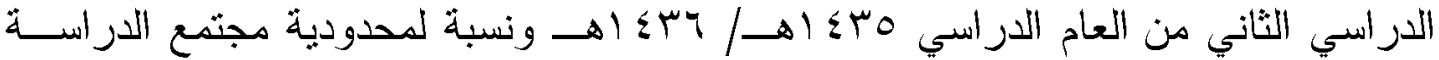

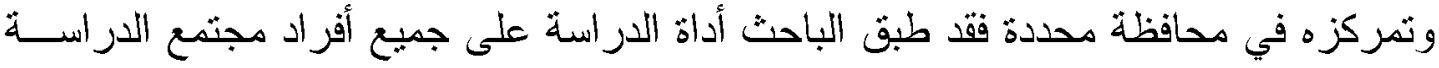
وكان تقسيمهز على النحو الثالي:

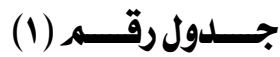

يوضحتوزيع مجتمع الدراسة

\begin{tabular}{|c|c|}
\hline حجم المجنمع الأصلي & البيان \\
\hline$r \leq$ & مديرون \\
\hline$\varepsilon r$ & مدير ات \\
\hline$V V$ & المجموع \\
\hline
\end{tabular}

وبعد النطبيق المبداني حصل الباحث على (rآ) استبانة صالحة للتحليل الإحصائي.

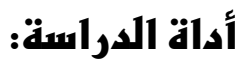

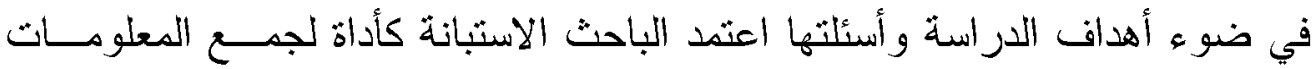
اللازمة للتعرف على درجة الرضا الوظيفي وتحديد معوقاته. و التي قاست الأبعاد الثالية

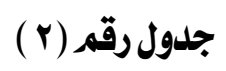

يوضح توزيع فترات الاستبانة على الأبعاد

\begin{tabular}{|c|c|}
\hline الفقـــــــرات & البعـــــــــد \\
\hline $14-1$ & ا ـ ظروف العمل \\
\hline ro-1 $\varepsilon$ & r ـ العلاقة مع إدارة النربية و التعليم \\
\hline$\Sigma\rceil-\Sigma$. & r ــ النمو و التقدم الوظيفي \\
\hline MI-YT & ع ـ المكانة الاجنماعية \\
\hline rq-rr & 0ـــ الر اتب الشهري \\
\hline $0 \leqslant-\leqslant V$ & ؟- العلاقة مع زملاء / زميلات العمل \\
\hline
\end{tabular}

\section{صدق أداة الدراسة:}

صدق الاسنبانة بعني التأكد من أنها سوف ثتيس ما أعدت لقياسه، كما يقصد بالصدق

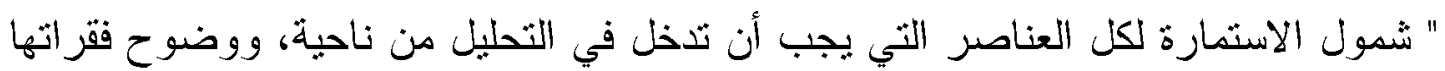

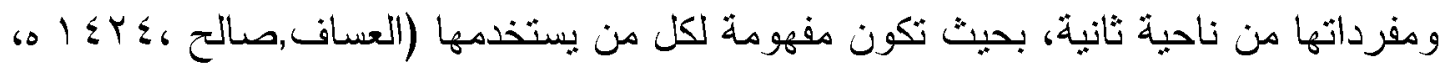




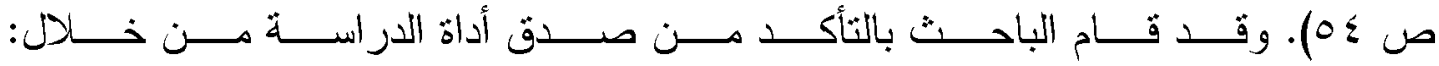
أ - الصدق الظاهري للأداة:

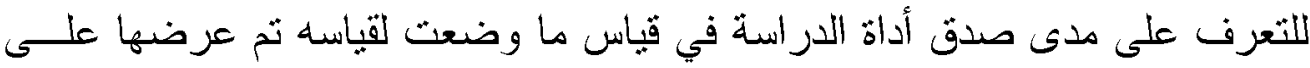

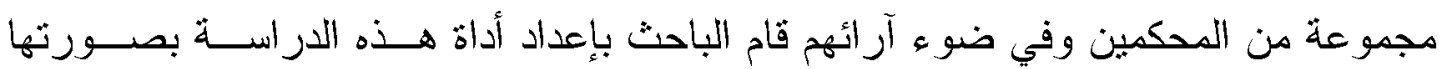

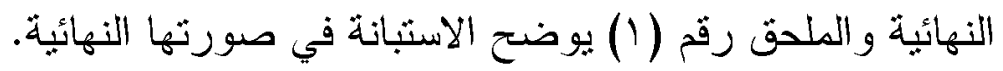
ب - صدق الاتساق الاخلي للأداة:

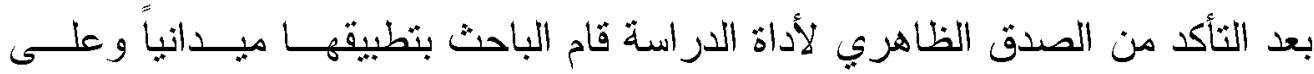

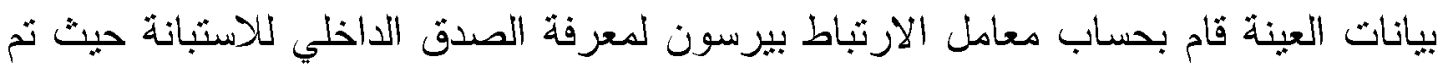

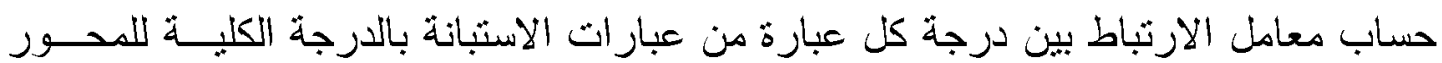
الذي تتنمي إليه العبارة كما توضح ذلآك الجداول التالية.

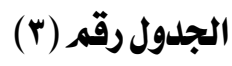
معاملات ارتباط بيرسون لعبارات المحور الأول بالدرجة الكلية للمحور

\begin{tabular}{|c|c|c|c|}
\hline معامل الارتباط بالمحور & رقم العبارة & معامل الارتباط بالمحور & رقهر العبارة \\
\hline 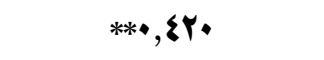 & $\wedge$ & $* \bullet, r \wedge \Lambda$ & 1 \\
\hline$* * \bullet, \leqslant 7$ & 9 & **•, ¿AY & $r$ \\
\hline **•, Trk & 1. & 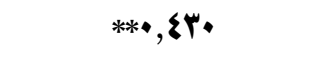 & $r$ \\
\hline$* * \bullet, Y \cdot r$ & 11 & $* * \bullet, 0 \leqslant 0$ & $\varepsilon$ \\
\hline$* *$, \&Yq & ir & $* * \bullet, \mathbb{Z}\{r$ & 0 \\
\hline$* * \bullet, 0 . r$ & ir & $* * \bullet$, ory & 7 \\
\hline- & - & $* * \bullet, 0 \leqslant \bullet$ & $r$ \\
\hline
\end{tabular}

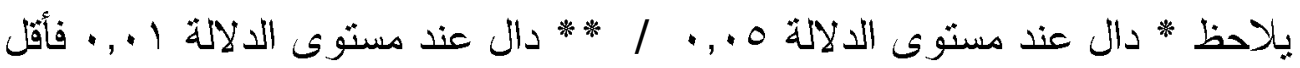
(₹) الجدول

معاملات ارتباط بيرسون لعبارات المحور الثاني باللدرجة الكلية للمحور

\begin{tabular}{|c|c|c|c|}
\hline معامل الارتباط بالمحور & رقمر العبارة & معامل الارتباط بالمحور & رقم العبارة \\
\hline$* * \bullet, \vee Y 7$ & r. & ***, Vฯr & 18 \\
\hline$* *, 790$ & rl & $* * 4,791$ & 10 \\
\hline$* *$, OVq & rr & $* * \bullet$, TVV & 17 \\
\hline$* *, 0.0$ & rr & 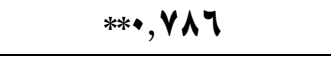 & iv \\
\hline$* * \bullet, V I 1$ & r乏 & $* * \bullet, \wedge \vee 1$ & IA \\
\hline$* * \bullet, Y \Sigma 1$ & ro & **•,ZrY & 19 \\
\hline
\end{tabular}

بلاحظ ** دال عند مستوى الالالة ا.,. فأقل 
الجدول رقم (0)

معاملات ارتباط بيرسوذ لعبارات المحور الثالث بالدرجة الكلية للمحور

\begin{tabular}{|c|c|c|c|}
\hline معامل الارتباط بالمحور & رقم العبارة & معامل الارتباط بالمحور & رقم العبارة \\
\hline$* *$, oOr & $\$ \varepsilon$ & $* *, 9 r Y$ & צ. \\
\hline$* *$, YOI & $\$ 0$ & $* * \bullet, 7 \cdots$ & $\$ 1$ \\
\hline **•, I YV & $\$ 7$ & $* *$, VYO & $\xi Y$ \\
\hline$* * \bullet \bullet$ \&Y. & $\xi V$ & $* * \bullet, Y \leqslant \Lambda$ & $\xi r$ \\
\hline
\end{tabular}

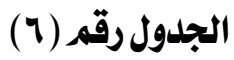

معاملات ارتباط بيرسوز لعبارات المحور الرابع بالدرجة الكلية للمحور

\begin{tabular}{|c|c|c|c|}
\hline معامل الارتباط بالمحور & رقمه العبارة & معامل الارتباط بالمحور & رقم العبارة \\
\hline$* *$, YO\& & rq & $* *, 110$ & $r y$ \\
\hline ***,ATr & $r \cdot$ & $* * \cdot, \wedge \cdot \xi$ & $r r$ \\
\hline **•, VIr & $r$ & $* *$, YOI & $r \Lambda$ \\
\hline
\end{tabular}

يلاحظ *** دال عند مستوى الدلالة 1 +,. فأقل

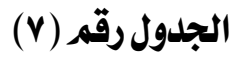

معاملات ارتباط بيرسوز لعبارات المحور الخامس باللدرجة الكلية للمحور

\begin{tabular}{|c|c|c|c|}
\hline معامل الارتباط بالمحور & رقم العبارة & معامل الارتباط بالمحور & رقمر العبارة \\
\hline$* * \bullet, 7 \wedge \Lambda$ & rq & $* *, V \leqslant Y$ & rr \\
\hline$* * \bullet, \wedge \bullet \bullet$ & rv & $* * \bullet, \vee 70$ & rr \\
\hline$* * *, V \cdot 0$ & ra & $* * \bullet, Y 09$ & rz \\
\hline$* *,, 711$ & rq & $* *$, YOI & ro \\
\hline
\end{tabular}

يلاحظ *** دال عند مستوى الدلالة إ.,. فأقل

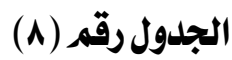

معاملات ارتباط بيرسوذ لعبارات المحور السادس بالدرجة الكلية للمحور

\begin{tabular}{|c|c|c|c|}
\hline معامل الارتباط بالمحور & رقم العبارة & معامل الارتباط بالمحور & رقم العبارة \\
\hline$* * \bullet, \wedge Y r$ & 01 & $* * \bullet, ~ \ \vee 9$ & $\leqslant V$ \\
\hline$* * \bullet, \wedge r r$ & or & $* * \bullet, \neg Y \varepsilon$ & $\xi \Lambda$ \\
\hline$* * \bullet, Y \leq Y$ & or & $* * \bullet, \wedge 0 ૫$ & $\leqslant 9$ \\
\hline$* * \bullet, 097$ & $0 \varepsilon$ & **•, YAY & 0. \\
\hline
\end{tabular}

يلاحظ ** دال عند مستوى الدلالة ا.,. فأقل 
يتضح من الجداول (r - ^) أن قيم معامل ارثباط كل عبارة مـن العبـار ات مــع

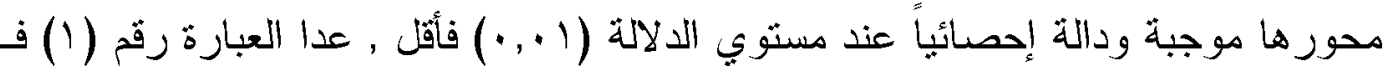

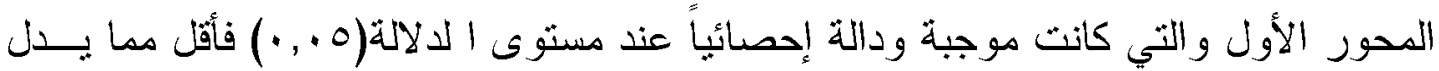
على صدق اتساق هذه العبارات وصداحيثها للنطبيق المبداني.

ثبات أداة الدراسةة:

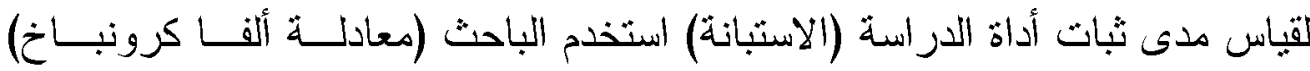

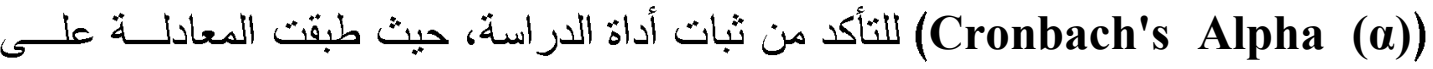
المجتمع لقياس الصدق البنائي والجدول رقم (9) يوضح معاملات ثبات أداة الدراسة.

\section{جلول رقهم (9)}

معامل ألفا كرونباخ لقياس ثبات أداة الدراسة

\begin{tabular}{|c|c|c|}
\hline ثبات المحور & عدد العبارات & أبعاد الاستبانة \\
\hline$\cdot, 7 \Lambda$ & ir & البعد الأول \\
\hline$\cdot, 19$ & ir & البعد الثاني \\
\hline$\cdot, \vee \vee$ & v & البعد الثالث \\
\hline$\cdot, \Lambda V$ & 7 & البعد الرابع \\
\hline$\cdot, \wedge \Lambda$ & $\wedge$ & البعد الخامس \\
\hline$\cdot, \Lambda V$ & $\wedge$ & البعد السادس \\
\hline$\cdot, 9 \xi$ & $0\}$ & معامل الثبات العام \\
\hline
\end{tabular}

ينضح من الجدول رقم (9) أن معامل الثبات لمحاور الدراسة جيد جداً حيث ثزاوح

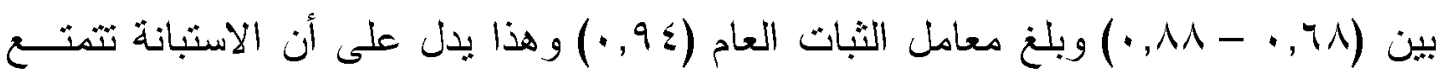
بدرجة عالية من الثبات يمكن الاعثماد عليها في النطبيق المبداني للار اسة.

\section{تدليل نتائج الدراسة وتفسيرها}

تهدف الاراسة الحالية إلى التعرف على درجة الرضا الوظيفي لدى مديري ومديرات

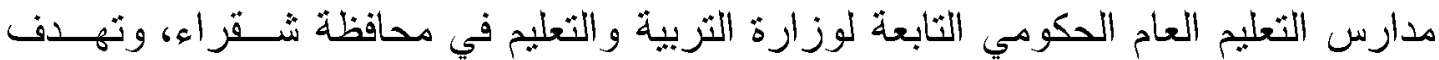

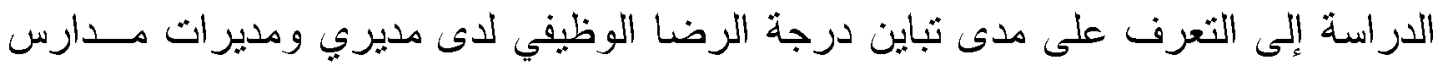

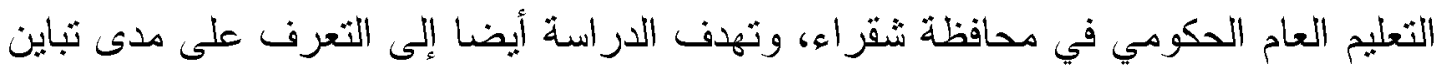

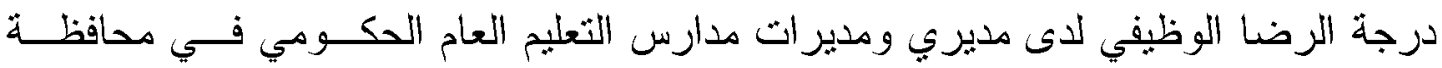


شقراء باختلاف المرحلة التعليمية ،وسعت الدراسة لتحقيق أهدافها من خلال الإجابــة عـن

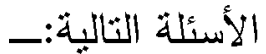

ا. ما درجة الرضا الوظيفي لاى دديري وهديرات مدارس التعليم العام الحكومي التابعــة

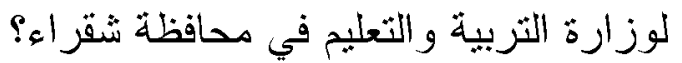

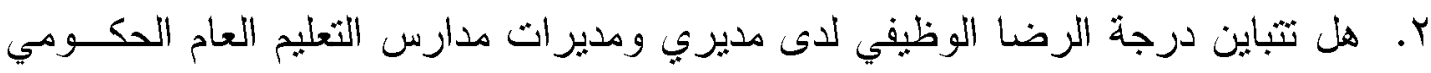
في محافظة شقر اء؟ r. هل تثباين درجة الرضا الوظيفي لدى مديري ومديرات مدارس التعليم العام الحكــومي في محافظة شقر اء باختلاف المرحلة التعليمية؟

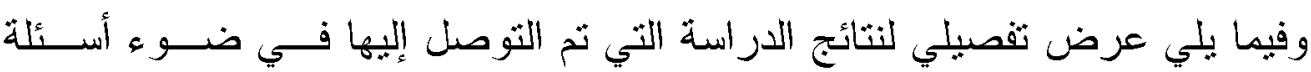
الدراسة، وأهدافها مع تفسير النتائج: أولاً: النتائج المتعلقة بوصف أفراد الدراسة:

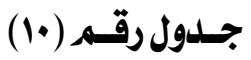
توزيع أفراد مجتمع الدراسة وفق متفير النوع

\begin{tabular}{|c|c|c|}
\hline النسبة & التكرار & النوع \\
\hline 07,0 & ro & أنثي \\
\hline$\varepsilon r, 0$ & $r V$ & ذكر \\
\hline$\% 1 \ldots$ & ry & المجموع \\
\hline
\end{tabular}

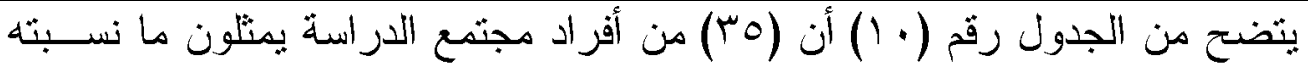

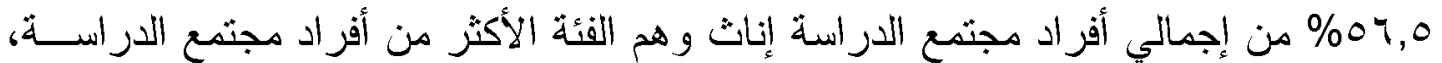

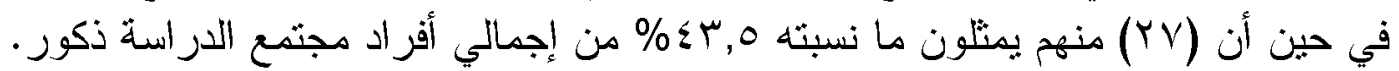

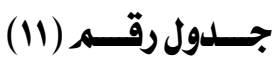

توزيع أفراد مجتمع الدراسة وفق متفير المؤهل الدراسي

\begin{tabular}{|c|c|c|}
\hline النسبة & التكرار & المؤهل الار اسي \\
\hline 07,0 & ro & بكالوريوس ثزبوي \\
\hline 7,0 & $\varepsilon$ & بكالوريوس غير ثربوي \\
\hline$r v, 1$ & r & مؤهل أخر \\
\hline$\% 1 \ldots$ & 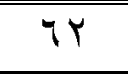 & المجموع \\
\hline
\end{tabular}

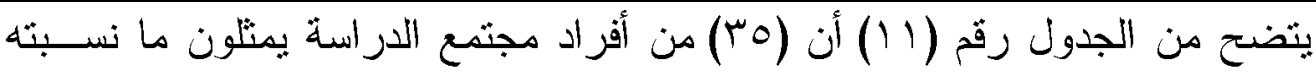

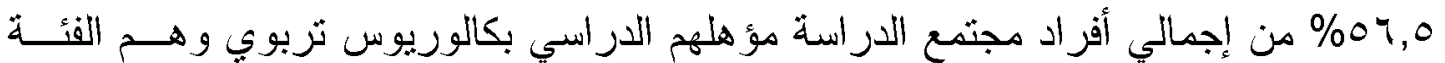

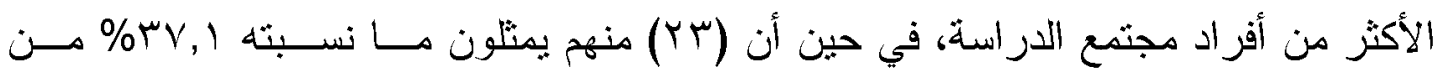




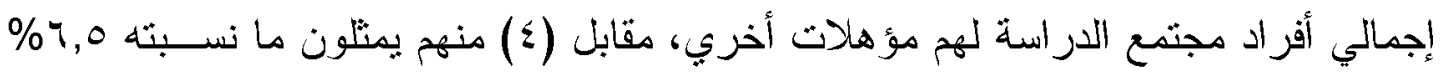
من إجمالي أفر اد مجنمع الدراسة مؤهلهم الدراسي بكالوريوس غير نربوب. جدول رقمـ (Ir)

توزيع أفراد مجتمع الدراسة وفق متفير علد سنوات الخبرة في مجال الإدارة الملدرسية

\begin{tabular}{|c|c|c|}
\hline النسبة & التكرار & عدد سنوات الخبرة \\
\hline$\varepsilon \cdot, r$ & ro & من 1 - 0 سنوات \\
\hline$r v, 1$ & r & من ج إلى • 1 سنوات \\
\hline YY,T & $1 \leq$ & | 1 سنة فأكثر \\
\hline$\% 1 \ldots$ & Tr & المجموع \\
\hline
\end{tabular}

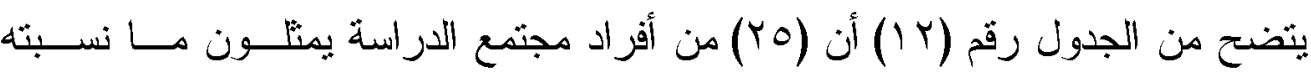

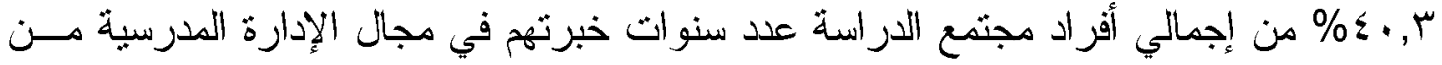

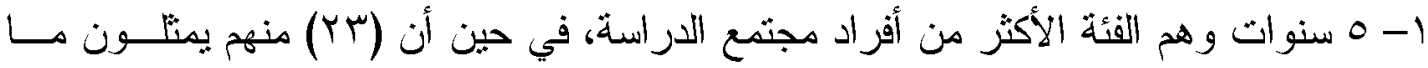
نسبته IrV,

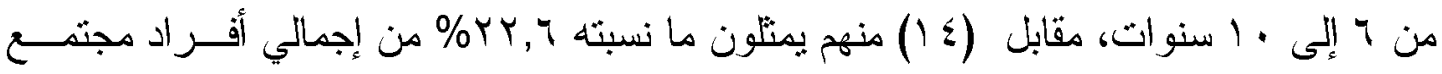
الدراسة عدد سنوات خبرثهم في مجال الإدارة المدرسية من 1 السنة فأكثر.

\section{جدول رقمه (ir)}

توزيع أفراد مجتمع الدراسة وفق متفير المرحلة التمليمية

\begin{tabular}{|c|c|c|}
\hline النسبة & التكرار & المرحلة التعليمية \\
\hline or, Y & r & الابتدائية \\
\hline $19, \varepsilon$ & Ir & المتوسط \\
\hline$M, 9$ & $\Lambda$ & الثانوية \\
\hline$r, Y$ & r & الابتدائية و المتوسطة \\
\hline $11, r$ & $\mathrm{~V}$ & المتو سطة و الثانوية \\
\hline$\% 1 \ldots$ & Tr & المجموع \\
\hline
\end{tabular}

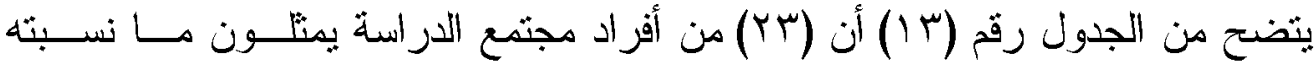
Y,r\% من إجمالي أفراد مجثمع الدراسة مرحلتهم التعليمية الابتدائبة وهم الفئة الأكثر من أفراد

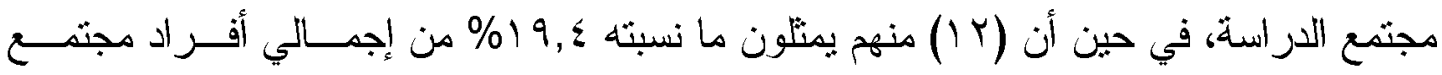

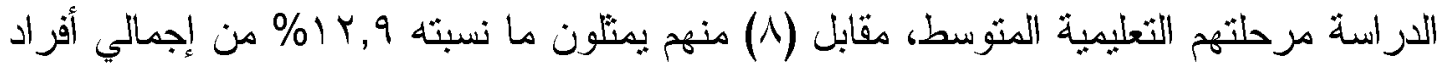




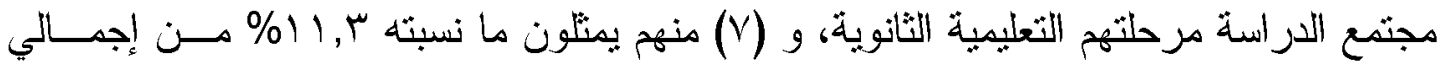

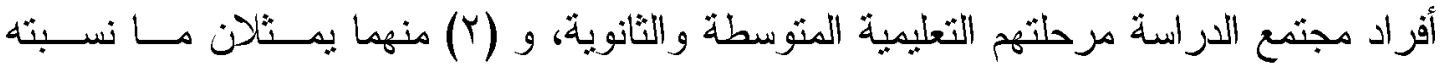

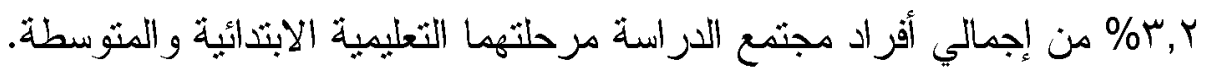

\section{ثانياً : النتائج المتعلقة بأسئلة الدراسة :}

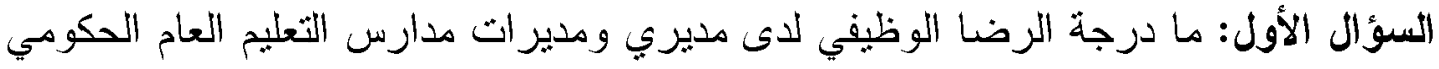

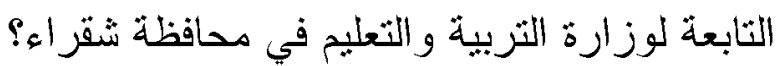

\section{1/ الرضا عز ظروف العمل: - ال}

اللثعرف على درجة الرضا الوظيفي عن ظروف العطل لدى مديري ومديرات مــدارس

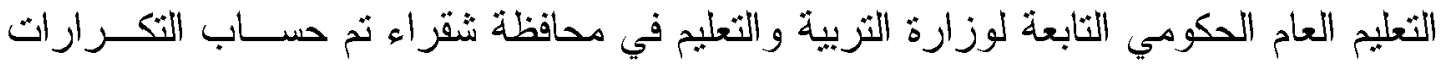

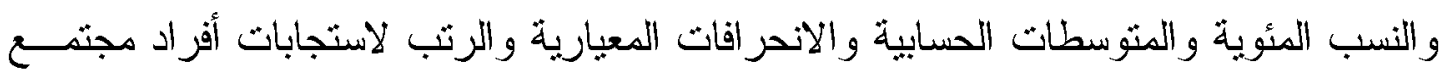

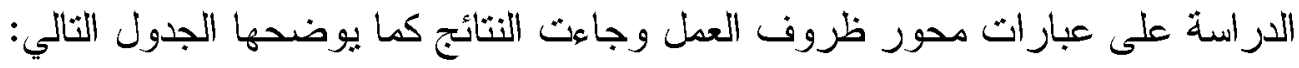

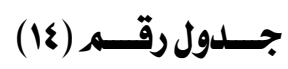

استجابات أفراد مجتمع الدراسة على عبارات محور ظروف العمل مرتبة تننازلياً حسب متوسطات الموافقة

\begin{tabular}{|c|c|c|c|c|c|c|c|c|c|c|}
\hline \multirow[b]{2}{*}{ الرتبة } & \multirow{2}{*}{ الانحراف } & \multirow{2}{*}{ الحسابي } & \multicolumn{5}{|c|}{ درجــة المواقتــة } & \multirow{2}{*}{ |التكرار } & \multirow[b]{2}{*}{ العبارة } & \multirow{2}{*}{ |العبارة } \\
\hline & & & لأوافق & لاأواقق & لا إداري & أوافق & تماماً & & & \\
\hline \multirow{2}{*}{1} & \multirow{2}{*}{$\cdot, 7 \xi$} & \multirow{2}{*}{$§, 0 \wedge$} & - & 1 & $r$ & 19 & ६. & 5 & \multirow{2}{*}{ أشعربالسعادة أثناء } & \multirow{2}{*}{$\xi$} \\
\hline & & & - & 1,7 & $r, r$ & $r \cdot, q$ & $7 \xi, 0$ & $\%$ & & \\
\hline \multirow{2}{*}{$r$} & \multirow[b]{2}{*}{$\cdot, \Lambda \cdot$} & \multirow{2}{*}{ sor } & - & $\varepsilon$ & - & 11 & $\xi$ & 5 & \multirow{2}{*}{ فترة الدواه كافية لإنجاز } & \multirow{2}{*}{1} \\
\hline & & & - & 7,0 & - & $r q, \cdot$ & $7 \xi, 0$ & $\%$ & & \\
\hline \multirow{2}{*}{$r$} & \multirow{2}{*}{$\cdot, r v$} & \multirow{2}{*}{$\xi, r V$} & - & $r$ & $r$ & rq & ri & 5 & \multirow{2}{*}{ قبيعة العمل تتناسب مع | } & \multirow{2}{*}{9} \\
\hline & & & - & $\mathfrak{\xi}, \wedge$ & $r, r$ & $\$ 1,9$ & $0 \cdot, \cdot$ & $\%$ & & \\
\hline \multirow{2}{*}{$\xi$} & \multirow{2}{*}{ - Ar } & \multirow{2}{*}{$\xi, H$} & - & $\varepsilon$ & r r & rr & rq & st & \multirow{2}{*}{ خلال معارسة بتحقيق ذاتي من } & \multirow{2}{*}{1.} \\
\hline & & & - & 7,0 & $r, r$ & $\xi \%, O$ & $\leq 9,1$ & $\%$ & & \\
\hline \multirow{2}{*}{0} & \multirow{2}{*}{$1,+1$} & \multirow{2}{*}{$\xi, Y\urcorner$} & - & $\Lambda$ & 1 & r. & Pr & st & \multirow{2}{*}{ تناسبني ساعات الدوام } & \multirow{2}{*}{7} \\
\hline & & & - & Ir,9 & 1,7 & $r r, r$ & or, r & $\%$ & & \\
\hline \multirow[b]{2}{*}{7} & \multirow[b]{2}{*}{1,17} & \multirow[b]{2}{*}{$\xi, \cdot \bullet$} & $\varepsilon$ & $\varepsilon$ & 0 & r६ & ro & st & \multirow{2}{*}{ 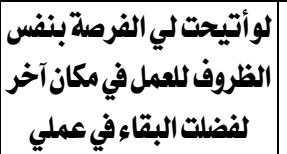 } & \\
\hline & & & 7,0 & 7,0 & $\Lambda, 1$ & $r \Lambda, V$ & $\varepsilon \cdot, r$ & $\%$ & & $\Lambda$ \\
\hline$y$ & 1.. & war & - & 9 & 7 & $r \Lambda$ & 19 & 5 & يوفر لي العمل الراحةو & II \\
\hline & $1, \cdots$ & Tוף, & - & $1 \xi, 0$ & $9, Y$ & $\$ 0, r$ & $r \cdot, 7$ & $\%$ & الطمأنينة & 11 \\
\hline
\end{tabular}




\section{تابع جدول رقم (\&)}

استجابات أفراد مجتمع الدراسة على عبارات محور ظروف العمل مرتبة تننازليا حسب متوسطات الموافقة

\begin{tabular}{|c|c|c|c|c|c|c|c|c|c|c|}
\hline \multirow[b]{2}{*}{ الرتبة } & \multirow{2}{*}{ الانخراف } & \multirow{2}{*}{ الحسوسط } & \multicolumn{5}{|c|}{ درجة المواققة } & \multirow{2}{*}{\begin{tabular}{|c|} 
\\
\end{tabular}} & \multirow[b]{2}{*}{ العبارة } & \multirow{2}{*}{ رقمث } \\
\hline & & & لأوافق & لا أواقق & لا إداري & أوافق & أوافق تماماً & & & \\
\hline \multirow[b]{2}{*}{$\wedge$} & \multirow[b]{2}{*}{ I, rI } & \multirow[b]{2}{*}{$r, \eta$. } & 7 & 11 & 1 & $r \wedge$ & 17 & st & \multirow{2}{*}{ |بيئة العمل ملائمة من حيث } & \multirow[b]{2}{*}{$v$} \\
\hline & & & $9, Y$ & IV,V & 1,7 & $\{0, r$ & ro, 1 & $\%$ & & \\
\hline \multirow{2}{*}{9} & \multirow{2}{*}{$1, r \varepsilon$} & \multirow{2}{*}{ r, ¿\& } & $r$ & IA & r & rr & ir & ك & \multirow{2}{*}{ لتيترغ لي عملي وقتـا كافيـا } & \multirow{2}{*}{0} \\
\hline & & & $\xi, \wedge$ & rq, & $r, r$ & $\varepsilon r, 0$ & 19,8 & $\%$ & & \\
\hline \multirow{2}{*}{1.} & \multirow{2}{*}{1,11} & \multirow{2}{*}{$r, r r$} & $r$ & r. & 1 & rz & 0 & 5 & \multirow{2}{*}{ 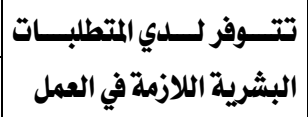 } & \multirow{2}{*}{ Ir } \\
\hline & & & $r, r$ & $r r, r$ & 1,7 & $\Delta\}, \wedge$ & $\wedge, 1$ & $\%$ & & \\
\hline \multirow{2}{*}{11} & \multirow{2}{*}{1,14} & \multirow{2}{*}{$r, \cdot \bullet$} & $r$ & rq & $r$ & ro & $\xi$ & st & \multirow{2}{*}{ 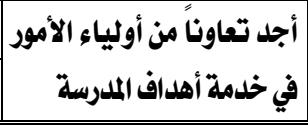 } & \multirow{2}{*}{$r$} \\
\hline & & & $r, r$ & $\{\eta, \wedge$ & $r, r$ & $\varepsilon \cdot r$ & 7,0 & $\%$ & & \\
\hline \multirow{2}{*}{ ir } & \multirow{2}{*}{$1,1 r$} & \multirow{2}{*}{$r, r)$} & 7 & rI & 1 & rr & 1 & 5 & \multirow{2}{*}{ كي كثرة الأعمال الإدارية توفر } & \multirow{2}{*}{$r$} \\
\hline & & & $q, \vee$ & $0 ., \cdot$ & 1,7 & $r v, 1$ & 1,7 & $\%$ & & \\
\hline \multirow{2}{*}{ ir } & \multirow{2}{*}{$1, r \wedge$} & \multirow{2}{*}{$r, 00$} & M & rq & 1 & 10 & 0 & st & \multirow{2}{*}{ | تتوفر للدي المتطلبات المادية } & Ir \\
\hline & & & 19,8 & $\leqslant\rceil, \wedge$ & 1,7 & $r \xi, r$ & $\wedge, 1$ & $\%$ & & \\
\hline & $\xi$ & $r, v \varepsilon$ & & & & & وسط العام & & & \\
\hline
\end{tabular}

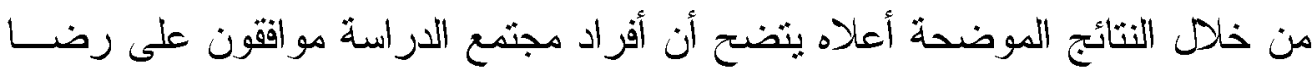
مديري ومديرات مدارس الثعليم العام الحكومي الثابعة لوزارة الثربية والتعليم في محافظة شقراء

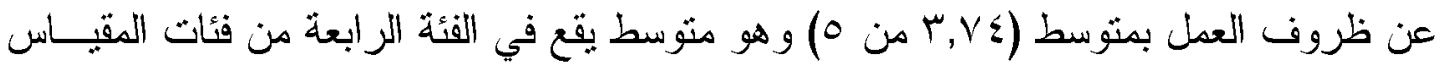

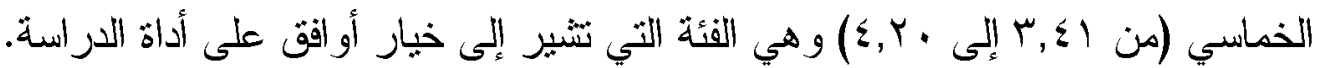

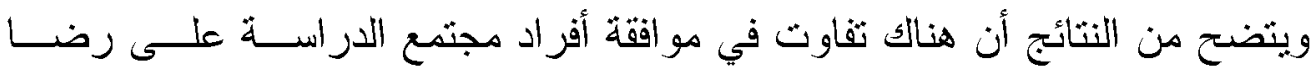
مديري ومديرات مدارس التعليم العام الحكومي التابعة لوزارة التربية والتعليم في محافظـــة

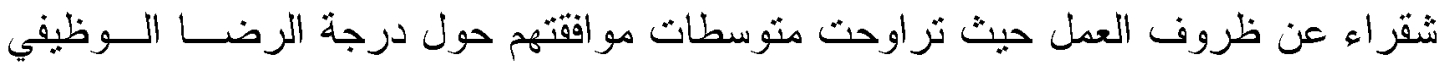

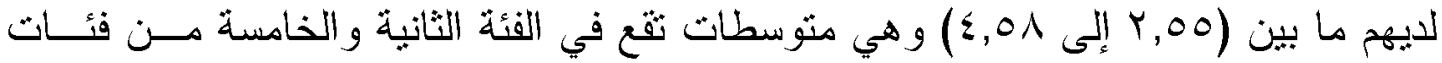

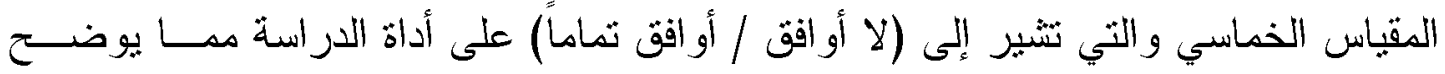
التفاوث في موافقة أفراد مجتمع الدراسة على درجة الرضا الوظيفي لايهم عن ظروف العمل

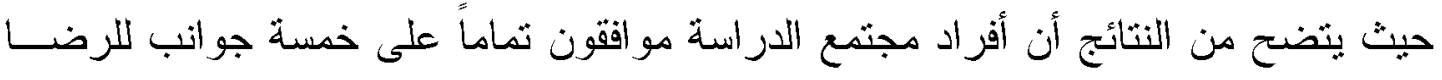




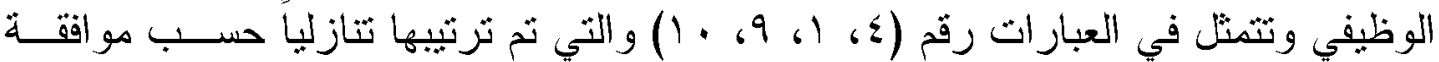
أفر اد مجتمع الدر اسة عليها ثماماً كالتالي:

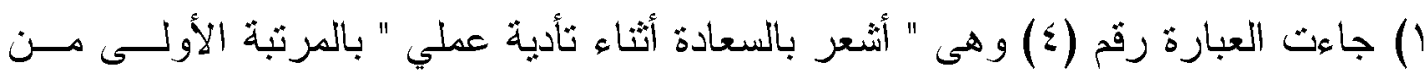

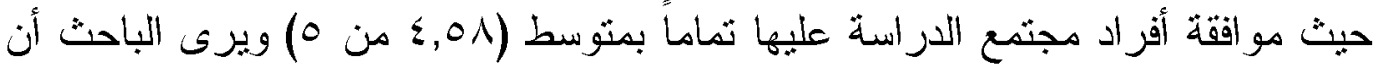

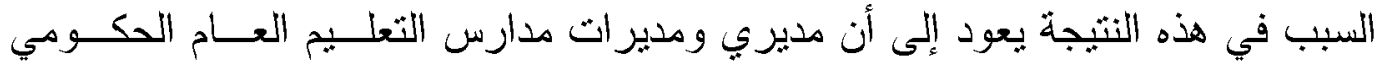
التابعة لوزارة التربية والتعليم في محافظة شُقراء لديهم قناعة بأهمية وجدوى عملهم في التي

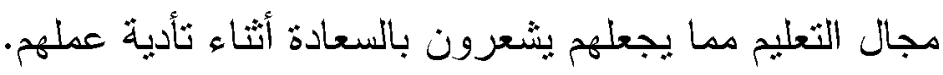

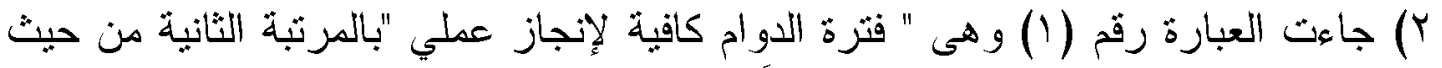

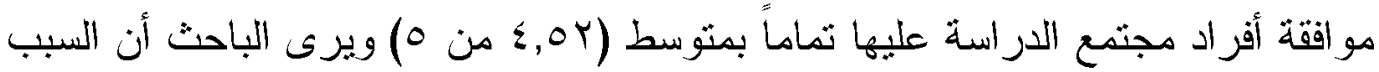

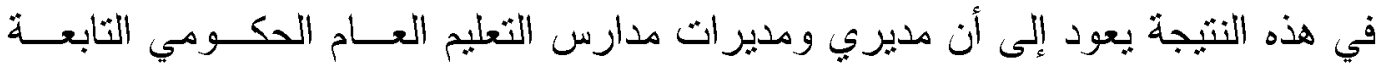

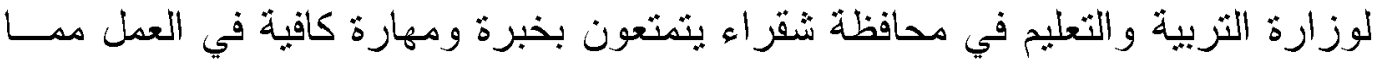

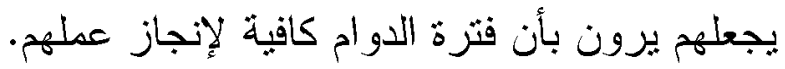

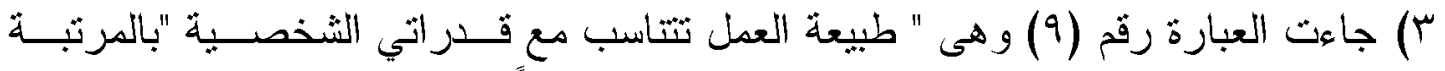

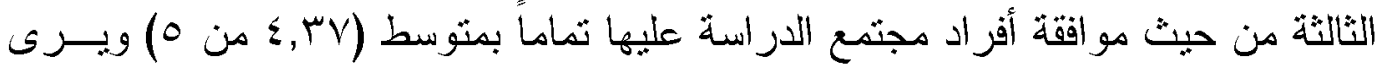

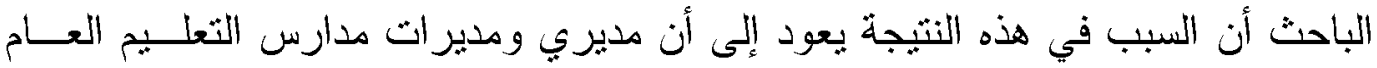

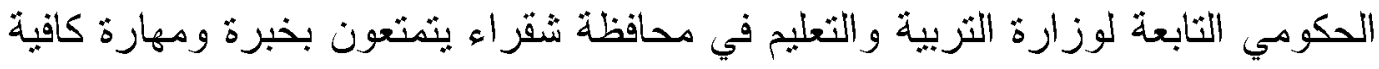

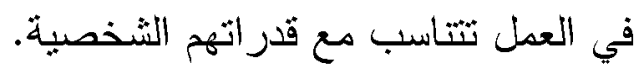

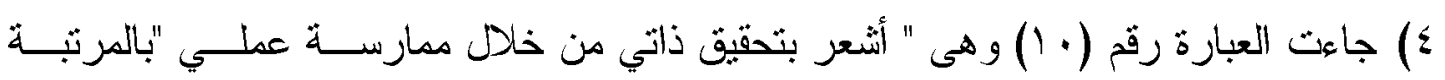

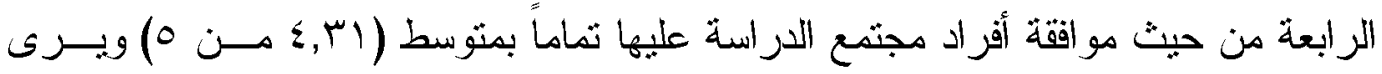

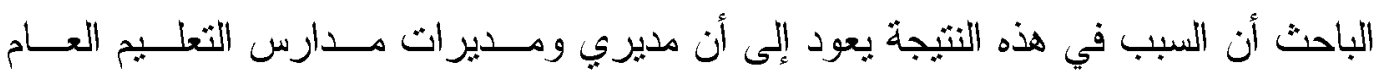

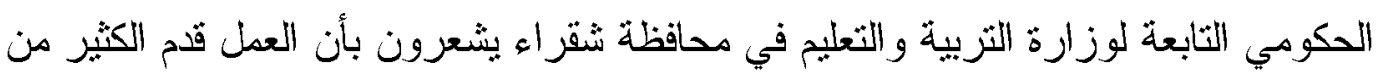
المهارات و المعارف لهم مما يجعلهم يشعرون بتحقيق ذاتهم من خلال ممارسة عملهم.

\section{r/ الر ضا العلاقة مع إدارة التربية والتعليم:}

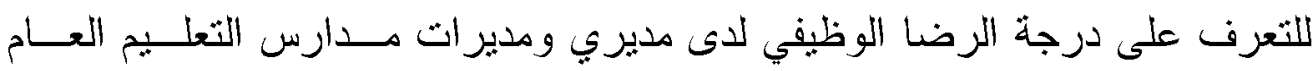

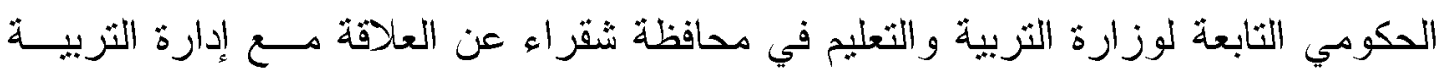

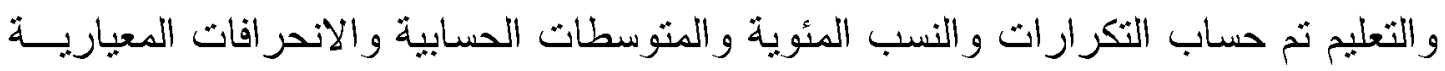

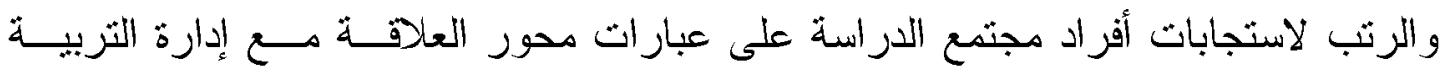

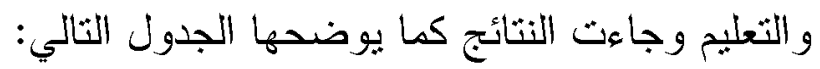




\section{جدول رقم (10)}

استجابات أفراد مجتمع الدراسة على عبارات محور العلاقة مع إدارة التربية والتعليه

مرتبة تنازلياً حسب متوسطات المواققة

\begin{tabular}{|c|c|c|c|c|c|c|c|c|c|c|}
\hline \multirow[b]{2}{*}{ 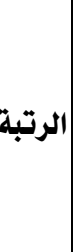 } & \multirow{2}{*}{ الانحراف } & \multirow{2}{*}{ المتوسط } & \multicolumn{5}{|c|}{ درجة المواقتة } & \multirow{2}{*}{ |التكرار } & \multirow[b]{2}{*}{ العبــــارة } & \multirow[b]{2}{*}{ رقم العبارة } \\
\hline & & & لأوافق & أواقق & إداري & |أوافق & توافق & & & \\
\hline \multirow[b]{2}{*}{1} & \multirow[b]{2}{*}{-V々. } & \multirow[b]{2}{*}{$\xi,\{\bigvee$} & - & $r$ & $r$ & rI & rq & ك & \multirow{2}{*}{ 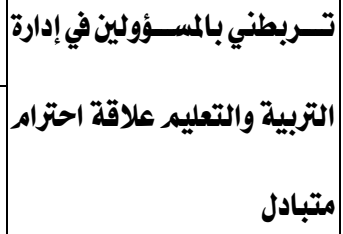 } & \multirow[b]{2}{*}{ YE } \\
\hline & & & - & $r, r$ & $\boldsymbol{\varepsilon}, \Lambda$ & $r r, q$ & $0 \wedge, 1$ & $\%$ & & \\
\hline \multirow{2}{*}{$r$} & \multirow{2}{*}{$\cdot$, Yo } & \multirow{2}{*}{$\varepsilon, r q$} & - & $r$ & $\varepsilon$ & rz & rr & st & \multirow{2}{*}{ 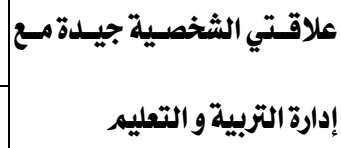 } & \multirow{2}{*}{ r. } \\
\hline & & & - & $r, r$ & 7,0 & $r \wedge, v$ & 01,7 & $\%$ & & \\
\hline \multirow{2}{*}{$r$} & \multirow{2}{*}{$\cdot, \vee \wedge$} & \multirow{2}{*}{$\xi, Y \xi$} & - & $r$ & v & rr & rq & st & \multirow{2}{*}{ بتثقة لتحقيق مهام الإشر اف التربـوي معي } & \multirow{2}{*}{ ro } \\
\hline & & & - & $r, r$ & $11, r$ & $\{r, 0$ & $\$ 1,9$ & $\%$ & & \\
\hline \multirow{2}{*}{$\varepsilon$} & \multirow{2}{*}{$1, \cdot \bullet$} & \multirow{2}{*}{, 17} & $r$ & 0 & $r$ & ro & ra & S & \multirow{2}{*}{ |إدارة التربية والتعليه } & \multirow{2}{*}{17} \\
\hline & & & $r, r$ & $\wedge, 1$ & $r, r$ & $\xi \cdot, r$ & $\S 0, r$ & $\%$ & & \\
\hline \multirow{2}{*}{0} & \multirow{2}{*}{$1, \cdot \bullet$} & \multirow{2}{*}{$r, \wedge l$} & $r$ & 7 & 1. & rA & 17 & st & \multirow[t]{2}{*}{ يقددر المسؤولون في إدارة التعليم } & \multirow{2}{*}{11} \\
\hline & & & $r, r$ & $9, v$ & 17,1 & $\S 0, r$ & $r o, \Lambda$ & $\%$ & & \\
\hline \multirow[b]{2}{*}{7} & \multirow[b]{2}{*}{$1, \bullet \wedge$} & \multirow[b]{2}{*}{ r,vq } & 1 & ir & $r$ & M & 10 & 5 & \multirow{2}{*}{ 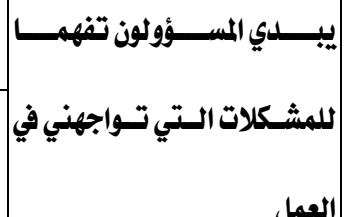 } & \\
\hline & & & 1,7 & 19,8 & $\boldsymbol{\varepsilon}, \boldsymbol{\Lambda}$ & $0 \cdot, \cdot$ & $r \xi, r$ & $\%$ & & iv \\
\hline & & & $r$ & 9 & 1. & rq & ir & st & أجــــ تقــليرا مـن المسـؤوليز في & \\
\hline$\checkmark$ & $1, \cdot 7$ & $r, 70$ & $r, r$ & $1 \xi, 0$ & 17,1 & $\leqslant 7, \wedge$ & 19,8 & $\%$ & |إدارة التربيــــة التعلـــيــــإزاء & $1 \varepsilon$ \\
\hline
\end{tabular}


تابع جدول رقم (10)

استجابات أفراد مجتمع الدراسة على عبارات محور العلاقة مع إدارة التربية والتعليم مرتبة تنازلياً حسب

متوسطات المواققة

\begin{tabular}{|c|c|c|c|c|c|c|c|c|c|c|}
\hline \multirow[b]{2}{*}{ | الرتبة } & \multirow{2}{*}{ الانحراف } & \multirow{2}{*}{ الحسابي التوسط } & \multicolumn{5}{|c|}{ درجة الموافقة } & \multirow{2}{*}{ النسبة \% التكرار } & \multirow[b]{2}{*}{ العبــــــارة } & \multirow{2}{*}{ العبارة } \\
\hline & & & لا لأواقق & ل ل ل أوافق & ل إداري & أواقق & تماماً & & & \\
\hline \multirow{2}{*}{$\wedge$} & \multirow{2}{*}{1,11} & \multirow{2}{*}{ r, } & $r$ & 11 & $\varepsilon$ & $r r$ & 11 & 5 & أتلقى إشرافا إداريا كافيا من & \multirow{2}{*}{$r r$} \\
\hline & & & $r, r$ & $r q, \cdot$ & 7,0 & $\{r, 0$ & $i v, v$ & $\%$ & |قبل كوادر مؤهلة & \\
\hline \multirow[b]{2}{*}{9} & \multirow[b]{2}{*}{$\cdot, \wedge \wedge$} & \multirow[b]{2}{*}{$r, r r$} & $r$ & $\wedge$ & rr & $r q$ & $r$ & ك & تلاقي اقتراحاتي مواقتة من & \multirow[b]{2}{*}{10} \\
\hline & & & $r, r$ & $1 r, q$ & $r v, 1$ & $\$ 1,9$ & $\mathfrak{k}, \wedge$ & $\%$ & |التســـؤلين في إدارة التربيــة & \\
\hline \multirow[b]{2}{*}{1.} & \multirow[b]{2}{*}{$1,1 r$} & \multirow[b]{2}{*}{$r, r \mu$} & $r$ & 19 & 9 & rq & 0 & ك & تفـوض لـي صـلاحية كافيـة & \multirow[b]{2}{*}{ rI } \\
\hline & & & $\xi, \wedge$ & $r \cdot, \uparrow$ & $9, \vee$ & $\leqslant 7, \wedge$ & $\wedge, 1$ & $\%$ & |أقور بهـهـاز مهـام العمـل الــني & \\
\hline \multirow[b]{2}{*}{11} & \multirow[b]{2}{*}{1,11} & \multirow[b]{2}{*}{$\uparrow, \bullet \uparrow$} & $r$ & rq & $\xi$ & rq & $\xi$ & ك & تتاح لي الفرصة للمشـاركة & \multirow[b]{2}{*}{$r r$} \\
\hline & & & $r, r$ & §1, १ & $0 . .7$ & $\$ 1,9$ & 7,0 & $\%$ & 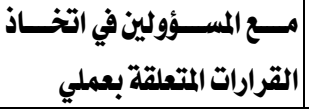 & \\
\hline \multirow[b]{2}{*}{ ir } & \multirow[b]{2}{*}{$1,1 \pi$} & \multirow[b]{2}{*}{$1,9 \xi$} & $r \Lambda$ & $r$ & $\varepsilon$ & $r$ & $r$ & ك & يأخذ المسؤولون برأيسي أثنـاء & \multirow[b]{2}{*}{19} \\
\hline & & & $\varepsilon 0, r$ & $r r, q$ & 7,0 & $11, r$ & $r, r$ & $\%$ & |تمدسيين معلمين مستجدين في & \\
\hline & , IV & $r, \boldsymbol{T r}$ & & & & & ط الد & 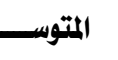 & & \\
\hline
\end{tabular}

من خلال النتائج الموضدة أعلاه بتضح أن أفراد مجتمع الدراسة مو افقون على رضا

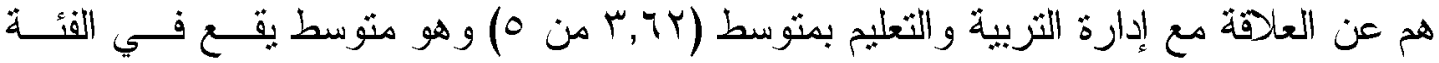

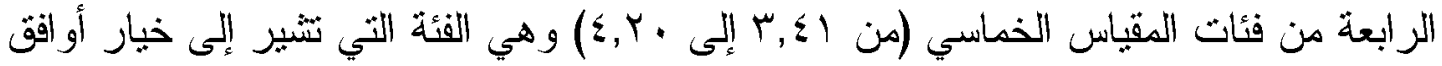

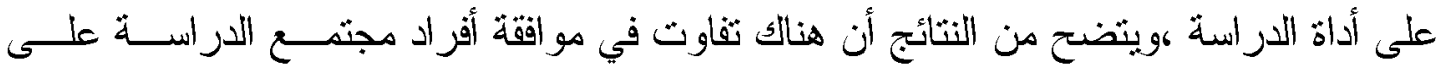

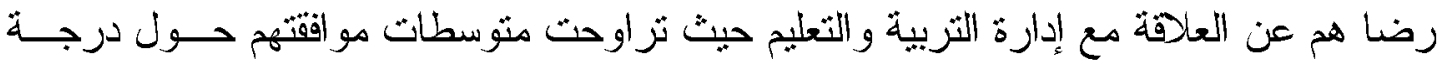

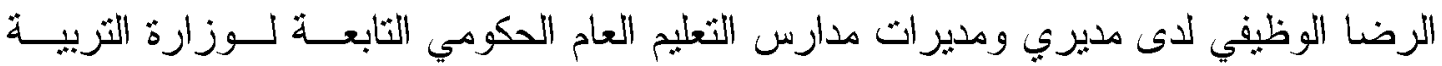

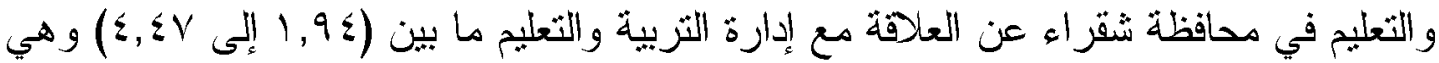

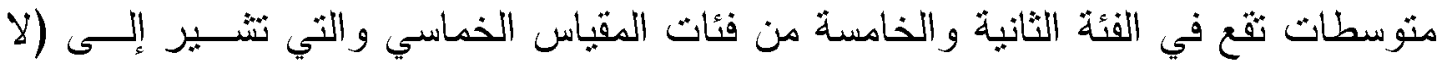
أو افق / أو افق تماماً) على أداة الدراسة مما يوضح التفاوت في موافقة أفراد مجتمع الدراسة 
على درجة الرضا عن العلاقة مع إدارة الثربية والنعليم حيث بتضـح من النتـائج أن أفــراد

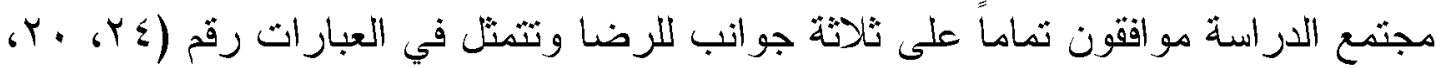

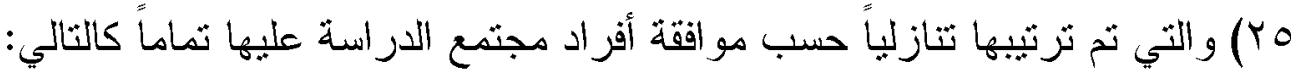

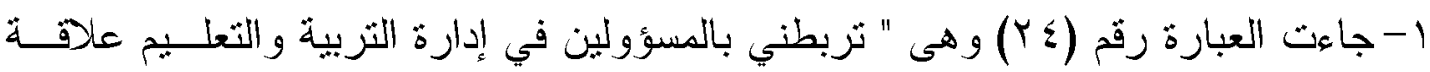

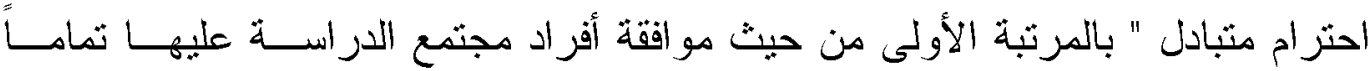

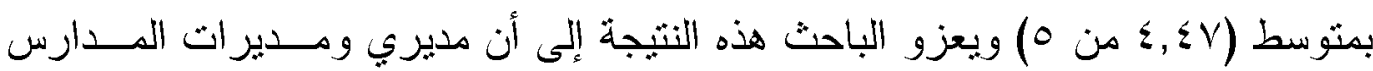

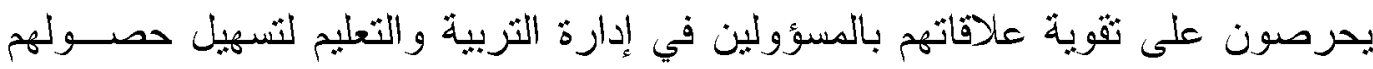
على الدعم وتوفير منطلبات العمل لمدارسهم ولذلك عادة ما تربطهم بالمسؤولين في إدارة التربية و التعليم علاقة احتر ام منبادل.

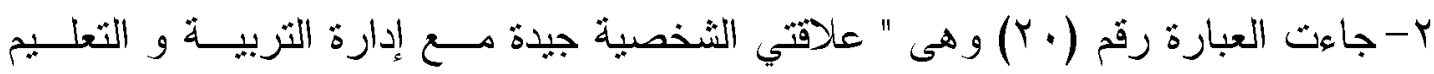

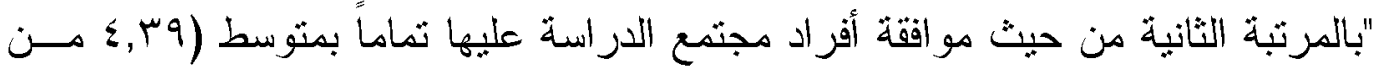

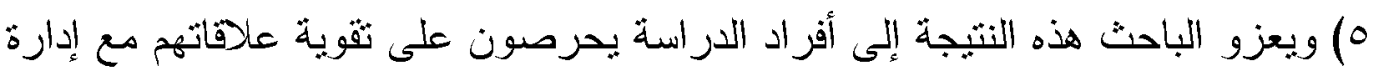

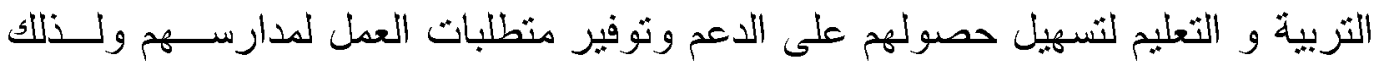
عادة ما تكون علاقاتهم الثخصية جيدة مع إدارة التربية و التعليم.

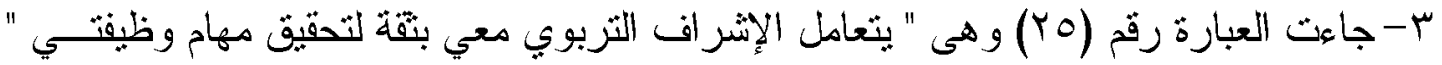

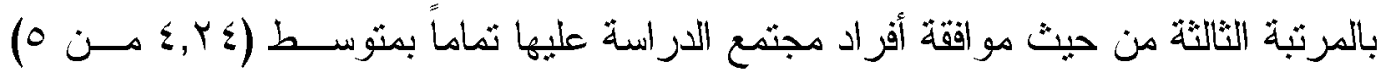
ويعزو الباحث هذه النتيجة إلى أن مديري ومديرات المدارس بثمنعون بالخبرة و القــدرة

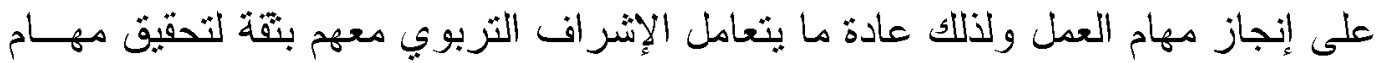

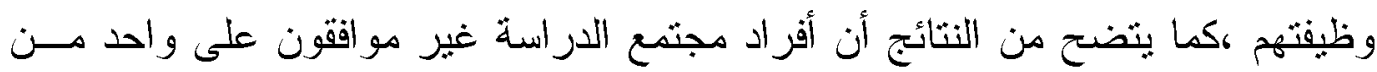

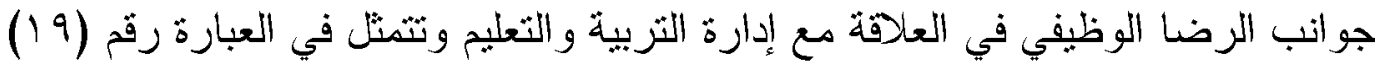

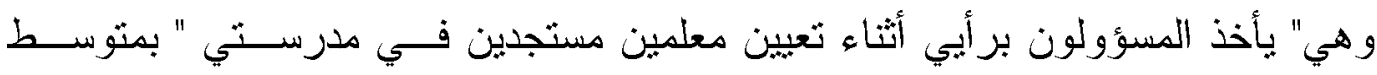

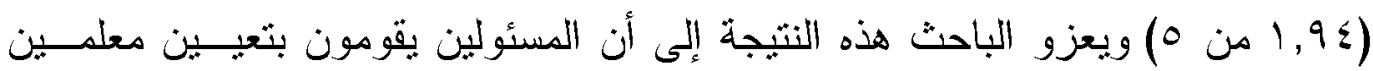
مستجدين في الددارس وفق رؤيتهم لاحتباجات هذه الدارس ولذلك فهم عادة لا بأخذون برأي مديري ومديرات المدارس في هذا الجانب.

\section{"स| / الرضا عز النمو والنقدم الوظيفير:}

للتعرف على درجة الرضا الوظيفي عن النمو والتقدم الوظيفي لدى مديري ومديرات مدارس التعليم العام الحكومي التابعة لوزارة النزبية والتحليم في محافظة شُقر اء تم حسبـاب التكرارات والنسب المئوية و المنوسطات الحسابية والانحر افات المعيارية و الرتب لاستجابات 
أفراد مجتمع الدراسة على عبارات محور النمو والثقدم الوظبفي وجاءت النتائج كما يوضحها

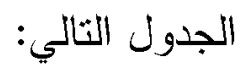

\section{جدول رقم (17) - (17) - (20)}

استجابات أفراد مجتمع الدراسة على عبارات محور النمووالتقده الوظيفي

مرتبة تننازليا حسب متوسطات المواققة

\begin{tabular}{|c|c|c|c|c|c|c|c|c|c|c|}
\hline \multirow[b]{2}{*}{ 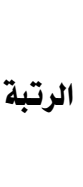 } & \multirow{2}{*}{ الانحراف } & \multirow{2}{*}{ المتوسط الهسابي } & \multicolumn{5}{|c|}{ درجة المواقةة } & \multirow{2}{*}{ النسبة \% التكرار } & \multirow[b]{2}{*}{ 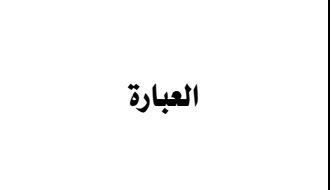 } & \multirow{2}{*}{ رقار } \\
\hline & & & |أوافق & لا لاوافق & ل إداري & أوافق & تواقً & & & \\
\hline \multirow{2}{*}{1} & \multirow{2}{*}{$1, \cdot r$} & \multirow{2}{*}{ r,^o } & 1 & 1. & 1 & ro & 10 & 5 & \multirow{2}{*}{ 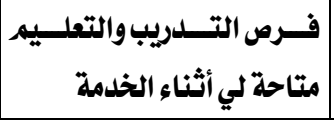 } & \multirow{2}{*}{$\$ 1$} \\
\hline & & & 1,7 & 17,1 & 1,7 & 07,0 & $r \xi, r$ & $\%$ & & \\
\hline \multirow{2}{*}{$r$} & \multirow{2}{*}{$1, \cdot r$} & \multirow{2}{*}{$r, \mathrm{r}$} & - & ir & 7 & r. & $1 \varepsilon$ & 5 & \multirow{2}{*}{ |الفـرص متاحسة لـي لتتنميــة } & \multirow{2}{*}{$\varepsilon \cdot$} \\
\hline & & & - & $19, ₹$ & $9, \vee$ & $\{\wedge, \xi$ & rr,, & $\%$ & & \\
\hline \multirow[b]{2}{*}{$r$} & \multirow[b]{2}{*}{$\cdot, 919$} & \multirow[b]{2}{*}{$r, 7 \Lambda$} & - & 1. & 9 & rร & 9 & 5 & \multirow{2}{*}{ 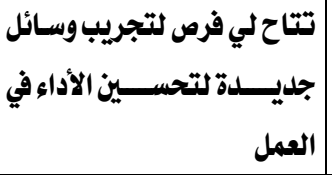 } & \multirow[b]{2}{*}{$\llbracket \varepsilon$} \\
\hline & & & - & 17,1 & $1 \varepsilon, 0$ & $\Delta\{, \Lambda$ & $1 \varepsilon, 0$ & $\%$ & & \\
\hline \multirow[b]{2}{*}{$\xi$} & \multirow[b]{2}{*}{$1, r 1$} & \multirow[b]{2}{*}{$r, I r$} & 9 & iv & $\wedge$ & ro & 9 & 5 & \multirow{2}{*}{ 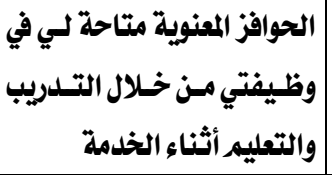 } & \multirow[b]{2}{*}{ st } \\
\hline & & & $9, Y$ & $r Y, \xi$ & $1 r, q$ & $\xi \cdot, r$ & $9, Y$ & $\%$ & & \\
\hline \multirow{2}{*}{0} & \multirow{2}{*}{ 1, ro } & \multirow{2}{*}{ r,^o } & $1 \varepsilon$ & ir & 9 & r. & 7 & st & \multirow{2}{*}{ | وفتم الترقيـة في مجال عملي } & \multirow{2}{*}{$\leqslant 7$} \\
\hline & & & $r r, Y$ & rI, & $1 \varepsilon, 0$ & $r r, r$ & $9, Y$ & $\%$ & & \\
\hline \multirow{2}{*}{7} & \multirow{2}{*}{$1, r r$} & \multirow{2}{*}{$r, \wedge l$} & ir & 17 & 9 & 11 & 7 & 5 & |الترقية في مجال عملي متاحة & \\
\hline & & & ri, & ro, $\Lambda$ & $1 \varepsilon, 0$ & $r q, \cdot$ & $9, Y$ & $\%$ & لمن يستحقها & \\
\hline & & & $1 \varepsilon$ & 17 & $\wedge$ & iv & $\checkmark$ & 5 & فرص الترقي المادية متاحة لي & \\
\hline v & $1, r v$ & r,va & rr, 1 & $r o, \Lambda$ & $1 \%, 9$ & $r v, \xi$ & $11, r$ & $\%$ & | من خلال التـاء الخدمبي أو التعليـي & $\xi r$ \\
\hline & 19 & $r, r v$ & & & & & & 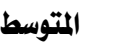 & & \\
\hline
\end{tabular}

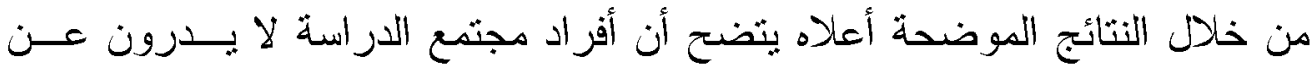

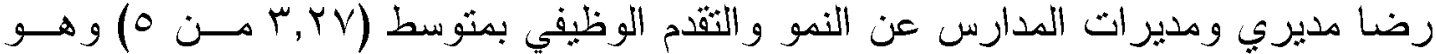

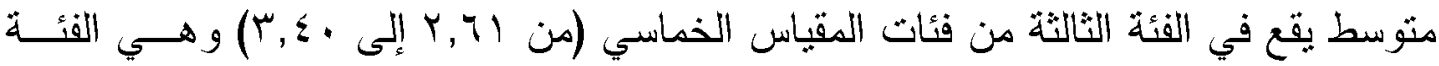
التي تثير إلى خيار لا أدري على أداة الدراسة. 
ويتضح من النتائج أن هناك تفاوت في مو افقة أفراد مجتمع الارلاسة على رضاهم عن النمو و التقدم الوظيفي حبث نراوحت متوسطات مو اقفتهم حول درجة الرضا عن النمو والثقدم

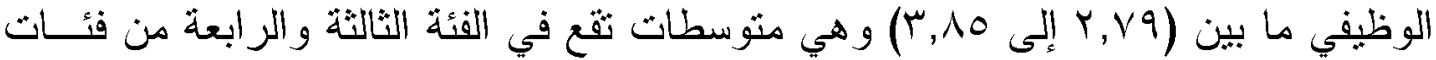

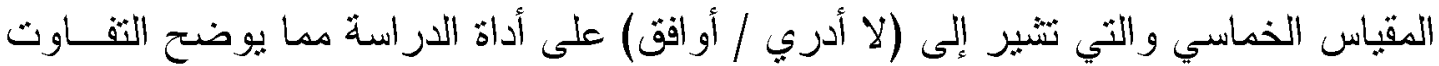

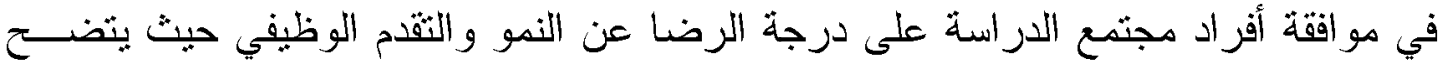

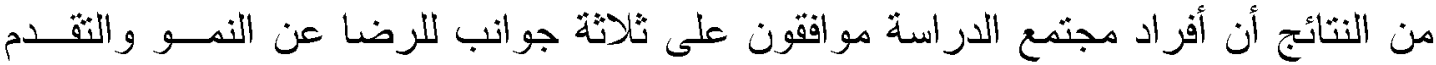

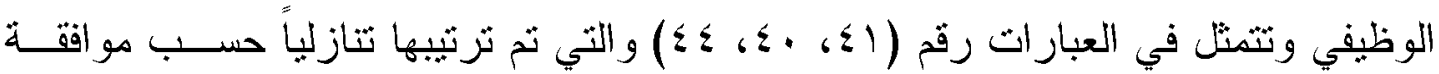

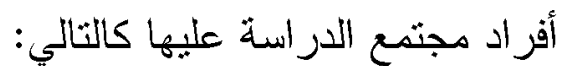
1-جاءت العبارة رقم (1) وهى " فرص التدريب و التعليم متاحة لي أثناء الخدمة " بالمرتبة

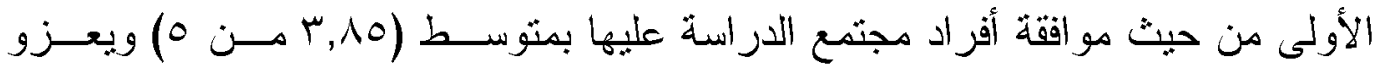
الباحث هذه النتيجة إلى أن المسئولين في إدارات التربية والتعليم بحرصون على تلى تحسين

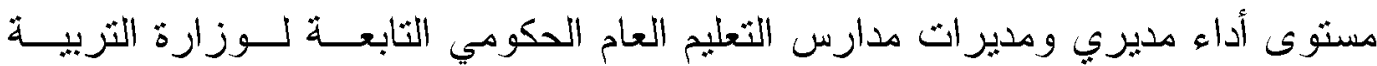
و التعليم مما يجعلهم يوفرون لهم التنريب و التحليم المناسب.

Y-جاءت العبارة رقم (•؛) و هى " الفرص متاحة لي لتنمبة مهار اتي في العمل "بالمرتبــة

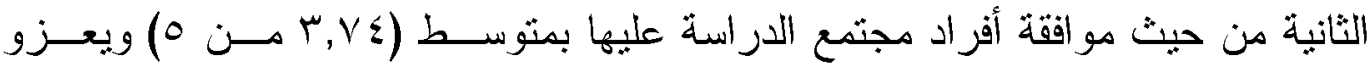
الباحث هذه النتيجة إلى أن المسؤولين في إدارات التربية والتعليم حريصون على توفير الفرص المناسبة لنطوير مهار ات مديري ومديرات المدارس مما بجعل الفرص متاحة لهم

$$
\text { التتمية مهار اتهم في العمل. }
$$

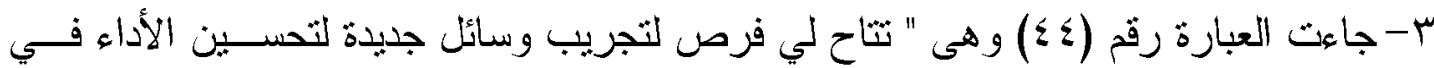

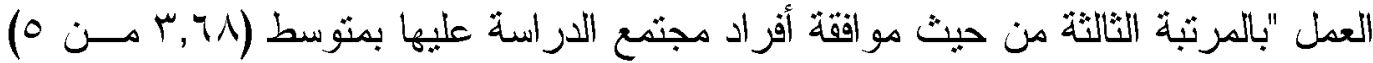
ويعزو الباحث هذه النتيجة إلى أن المسئولين في إدارات الثربية والتعليم بنركون لمديري

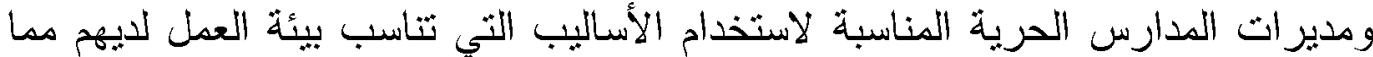
ينيح لهم فرص لنجريب وسائل جديدة لتحسين الأداء في العمل مما يؤدي إلـى تحســن أدائهم على المدى البعيد.

للتعرف على درجة الرضا الوظيفي عن المكانة الاجتماعية لاى مديري ووسـديرات

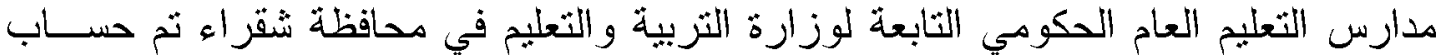
التكرارات و النسب المئوية والمنوسطات الحسابية والانحر افات المعيارية والرتب لاستجابات 
أفزاد مجتمع الدراسة على عبارات محور المكانة الاجتماعية وجاءت النتائج كما يوضـــها

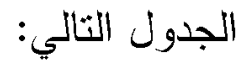

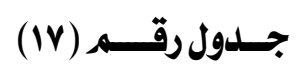

استجابات أفراد مجتمع الدراسة على عبارات محور المكانة الاجتماعية مرتبة تنازلياً حسب متوسطات المواققة

\begin{tabular}{|c|c|c|c|c|c|c|c|c|c|c|}
\hline \multirow[b]{2}{*}{ الرتبة الرتب } & \multirow{2}{*}{ المعياري } & \multirow{2}{*}{ الحسابي المتوسط } & \multicolumn{5}{|c|}{ درجة المواققة } & \multirow{2}{*}{ |التكرار } & \multirow[b]{2}{*}{ العبارة الع } & \multirow{2}{*}{ |العبارة } \\
\hline & & & لأواقق & ل الوافق & ل إداري & أواقق & تماماً & & & \\
\hline \multirow{2}{*}{1} & \multirow{2}{*}{$1, \cdot \varepsilon$} & \multirow{2}{*}{ ץ, 77} & $r$ & 9 & $\wedge$ & rr & 11 & كt & توفر مهنتي الحاليـة لأسرتي & r \\
\hline & & & $r, r$ & $\xi \xi, 0$ & $1 r, q$ & 01,7 & $i v, r$ & $\%$ & سمعة اجتماعية طيبة & T* \\
\hline \multirow{2}{*}{$r$} & \multirow{2}{*}{$1, \cdot 9$} & \multirow{2}{*}{$r, 79$} & $r$ & 7 & ir & ra & ir & كt & يبـدي المجتمـع تقـليراكبيرا & 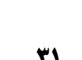 \\
\hline & & & $\xi, \wedge$ & $9, \vee$ & $19, \varepsilon$ & $\{9,1$ & 19,8 & $\%$ & |مهنتي & \\
\hline \multirow[b]{2}{*}{$r$} & \multirow[b]{2}{*}{$\cdot, 91$} & \multirow[b]{2}{*}{ ४, } & & 11 & 1. & $r \varepsilon$ & $\checkmark$ & ك & إن الأصــــقاء مـــذذوي المهــن & \\
\hline & & & & $i v, \gamma$ & 17,1 & $\Delta \xi, \Lambda$ & $11, r$ & $\%$ & | بفعل مهنتك يُشعرونك بـالاحترام & rA \\
\hline \multirow[b]{2}{*}{$\xi$} & \multirow[b]{2}{*}{1,11} & \multirow[b]{2}{*}{ r, } & $\varepsilon$ & ir & 1. & ro & 11 & ك & أشعر أنوظيفتي حققت لـي & \\
\hline & & & 7,0 & 19,8 & 17,1 & $\varepsilon \cdot, r$ & IV, $Y$ & $\%$ & |أطمحانـــة الاجتماعيــة الــتي & rq \\
\hline \multirow[b]{2}{*}{0} & \multirow[b]{2}{*}{$1, r$} & \multirow[b]{2}{*}{$r, r v$} & $r$ & 14 & $\varepsilon$ & rr & 1. & ك & يتيح لي عملي فرصة التعرف & \\
\hline & & & $\mathfrak{\xi}, \wedge$ & $r q, \cdot$ & 7,0 & $\varepsilon r, 0$ & 17,1 & $\%$ & 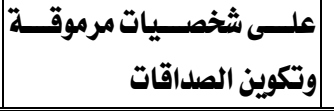 & rq \\
\hline \multirow[b]{2}{*}{1} & \multirow[b]{2}{*}{1,19} & \multirow[b]{2}{*}{$r, 10$} & 0 & 17 & is & 19 & $\wedge$ & 5 & أشعر أن وظيفتي تعطي مكانة & \\
\hline & & & $\Lambda, 1$ & rO,A & $r r, Y$ & $r \cdot, r$ & $1 r, q$ & $\%$ & |الأختمى | الاعية أعلى من الوظائف| & rV \\
\hline & & $r, \xi Y$ & & & & & 2 & س & & \\
\hline
\end{tabular}

من خلال النتائج الموضحة أعلاه بتضح أن أفراد مجتمع الدراسة مو افقون على رضا

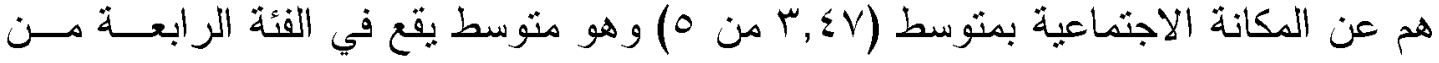

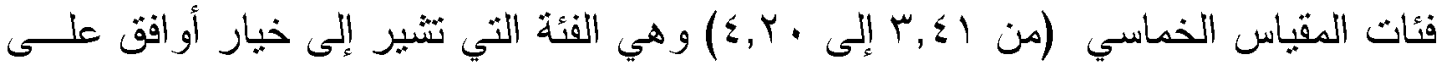

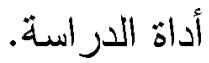

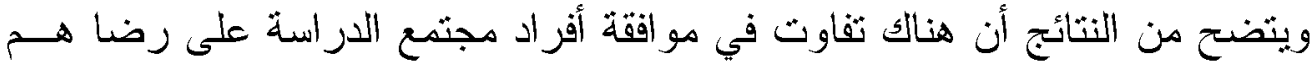

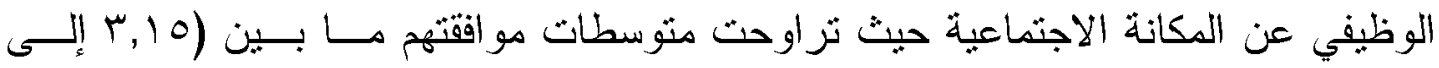




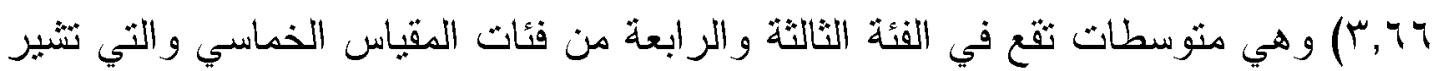
إلى (لا أدري / أوافق) حيث بتضح من النتائج أن أفراد مجتمع الدراسة مو اققون على ثلاثة

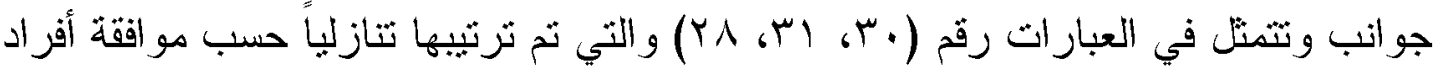
مجنمع الدراسة عليها كالتالي: مالي

1- جاءت العبارة رقم (•r) وهى " ثوفر مهنتي الحالية لأسرثي سمعة اجتماعيــة طيبــة "

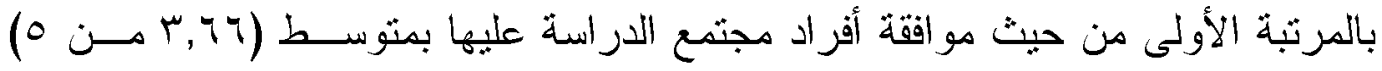

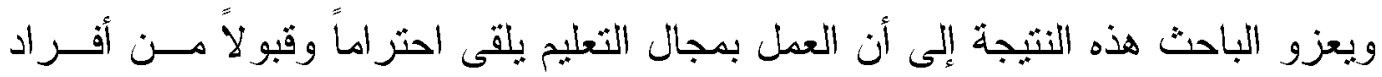
المجتمع و يرون بأن مهنتهم الحالية توفر لأسرثهم سمعة اجنماعية طيبة.

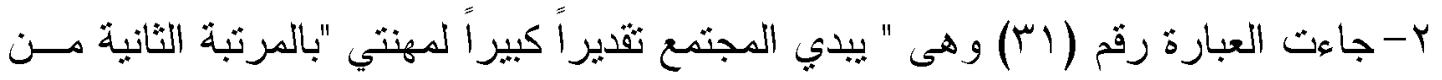

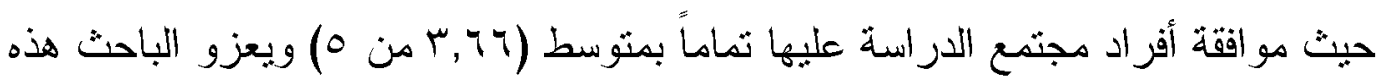
النتيجة إلى أن العمل بمجال التعليم وتوجيه الطلاب وثربية الجيل الصالح وزيارة أولياء

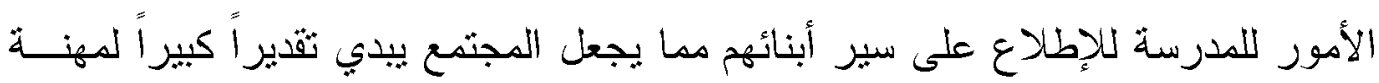

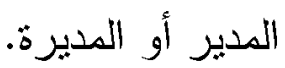

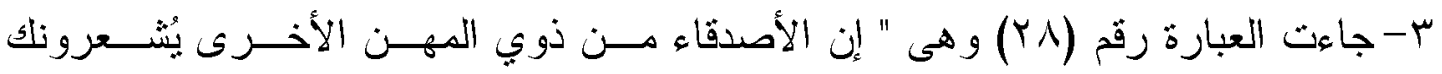

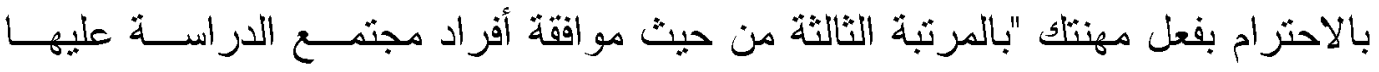

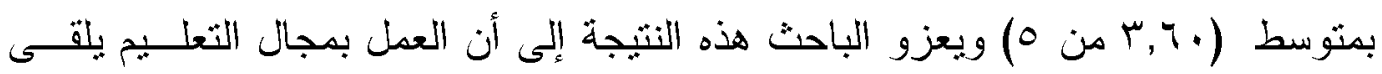

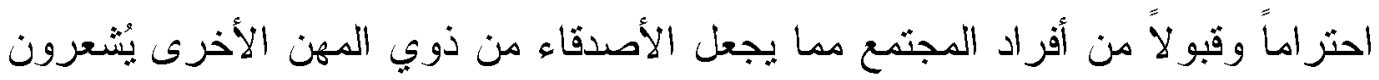
مديرب ومديرات مدارس التعليم العام الحكومي بالاحتر ام بفعل دهنتهم.

\section{/ الرضا عن الراتب الشهري:}

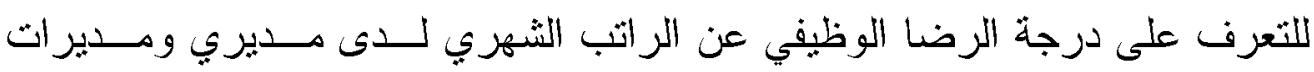

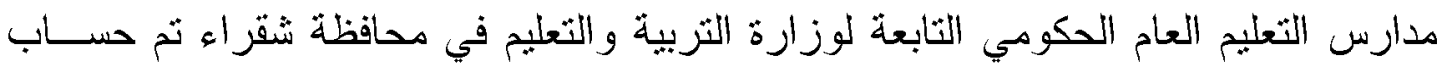
التكرارات و النسب المئوية والمتوسطات الحسابية والانحر افات المعيارية والرثب لاستجابات

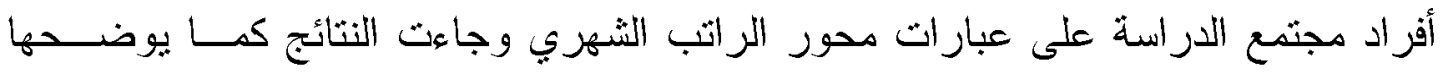

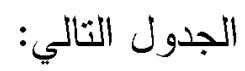




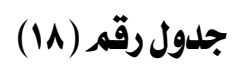

استجابات أفراد مجتمع الدراسة على عبارات محور الراتب الشهري مرتبة تنازليا حسب متوسطات المواققة

\begin{tabular}{|c|c|c|c|c|c|c|c|c|c|c|}
\hline \multirow[b]{2}{*}{ الرتبة } & \multirow{2}{*}{ الالمحراف } & \multirow{2}{*}{ الحسابي } & \multicolumn{5}{|c|}{ 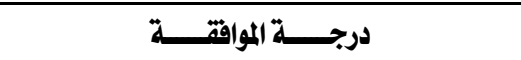 } & \multirow{2}{*}{ التكرار } & \multirow[b]{2}{*}{ العبـــــــارة } & \multirow{2}{*}{ رقمر } \\
\hline & & & لا أواقق & لاأوافق & لا إداري & أوافق & تماماً & & & \\
\hline \multirow{2}{*}{1} & \multirow{2}{*}{1, Yo } & \multirow{2}{*}{$r, v q$} & $\xi$ & 1. & $r$ & ro & r. & ك & \multirow{2}{*}{ |لأسطـي راتـبـي الاحتياجـات } & \multirow{2}{*}{ rr } \\
\hline & & & 7,0 & 17,1 & $\xi, \wedge$ & $\xi \cdot r$ & $r r, r$ & $\%$ & & \\
\hline \multirow{2}{*}{$r$} & \multirow{2}{*}{$1, r \wedge$} & \multirow{2}{*}{$r, 70$} & 7 & $r$ & $\wedge$ & rr & M & 5 & \multirow{2}{*}{ يؤمن الراتب لي مستقبلاً أمنا } & \multirow{2}{*}{ ro } \\
\hline & & & $9, Y$ & $11, r$ & $1 r, q$ & $r v, 1$ & $r q, \cdot$ & $\%$ & & \\
\hline \multirow{2}{*}{$r$} & \multirow{2}{*}{1, Yo } & \multirow{2}{*}{$r, 71$} & $\varepsilon$ & ir & $\varepsilon$ & rq & 17 & 5 & \multirow{2}{*}{ | يتناسب راتبي } & \multirow{2}{*}{ rz } \\
\hline & & & 7,0 & 19,8 & 7,0 & $\$ 1,9$ & ro, 1 & $\%$ & & \\
\hline \multirow{2}{*}{$\xi$} & \multirow{2}{*}{$1, Y 7$} & \multirow{2}{*}{ r, ro } & $\checkmark$ & 11 & 7 & $r q$ & 9 & ك & \multirow{2}{*}{ 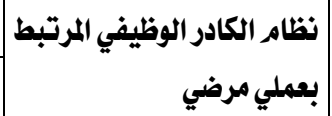 } & \multirow{2}{*}{$r V$} \\
\hline & & & $11, r$ & IV,V & $9, \vee$ & $\leqslant 7, \wedge$ & $1 \varepsilon, 0$ & $\%$ & & \\
\hline \multirow{2}{*}{0} & \multirow{2}{*}{1, Yo } & \multirow{2}{*}{$r, r$} & 1. & ir & $r$ & rr & 10 & ك5 & \multirow{2}{*}{ 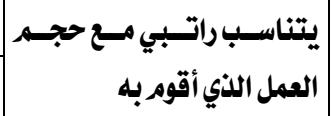 } & \multirow{2}{*}{ rr } \\
\hline & & & 17,1 & $r{ }^{\prime} \cdot$ & $r, r$ & ro,o & rE,, & $\%$ & & \\
\hline \multirow{2}{*}{7} & \multirow{2}{*}{$1, \cdot v$} & $r v a$ & 9 & 11 & H & 7 & 0 & st & يزيلدراتبي عن رواتب أقراني & 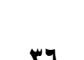 \\
\hline & & 1,19 & $1 \xi, 0$ & IV,V & $0 ., \cdot$ & $9, Y$ & $\wedge, 1$ & $\%$ & في وظائف الدولة الاخخى & 11 \\
\hline & & & ir & Pr & 7 & 19 & "r & st & أستطيع أن أوفر قسـطا كبير & \\
\hline$\checkmark$ & $1, Y \xi$ & $r, 77$ & $19, \&$ & ro,o & $9, Y$ & $r \cdot, 7$ & $\varepsilon, \Lambda$ & $\%$ & المستقبل من راتبي لتلبيـة احتياجـات & rq \\
\hline A & $8 \mathrm{u}$ & $r$ & rq & M & 7 & 11 & 1 & 5 & المكافـآت الماديـلة والامتيـازات & 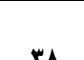 \\
\hline$\wedge$ & $1, \lambda$ & $\boldsymbol{r}, \cdot \wedge$ & $\$ 1,9$ & rq, & $9, \vee$ & IV,, $\mathrm{V}$ & 1,7 & $\%$ & المرتبطة بعملي مرضية & $T \Lambda$ \\
\hline & & $r, 10$ & & & & & & we & & \\
\hline
\end{tabular}

من خلال النتائج الموضحة أعلاه يتضح أن أفراد مجنمع الدراسة لا يـدرون عـن

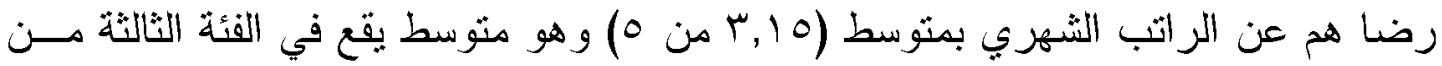

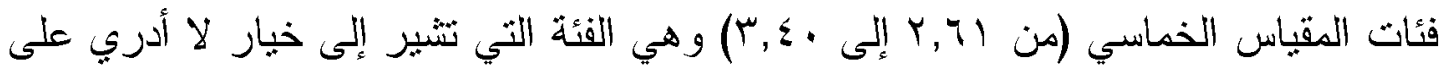

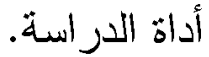

ويتضح من النتائج أن هناك تفاوت في مو اققة أفراد مجتمع الدراسة على رضاهم عن

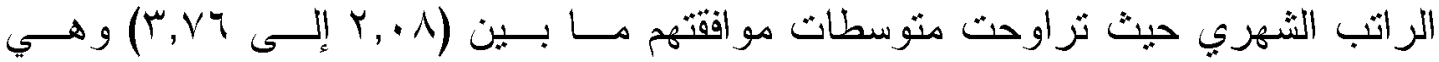

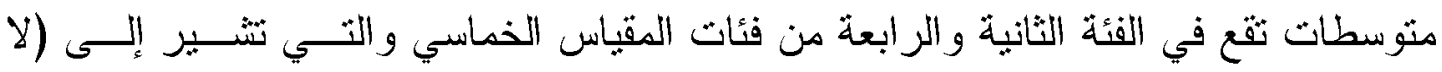

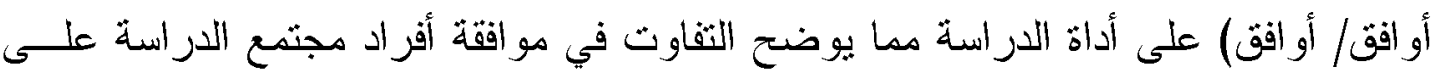


درجة الرضا الوظيفي حيث بنضح من النتائج أن أفراد مجتمع الدراسة مو افقون على جانبين

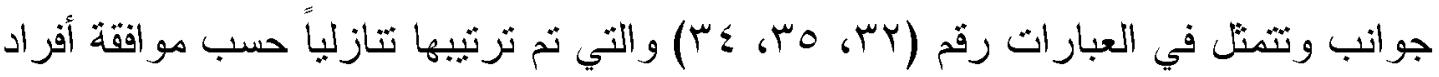

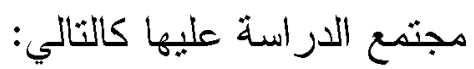

1- جاءت العبارة رقم (بץ) وهى " يغطي راتبي الاحتباجات الأساسية " بالمرنبة الأولى من

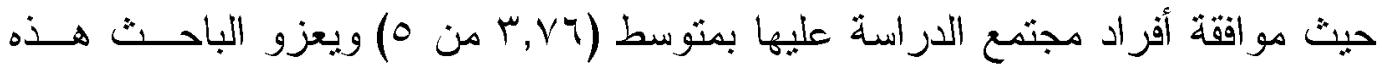

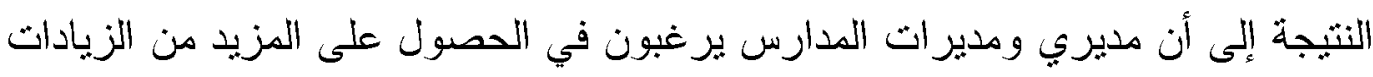

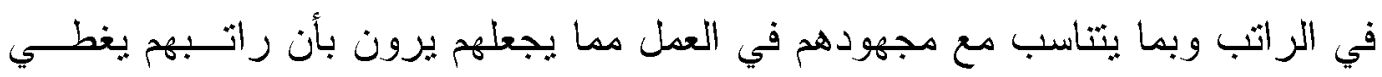

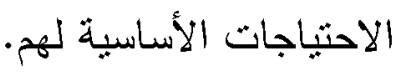

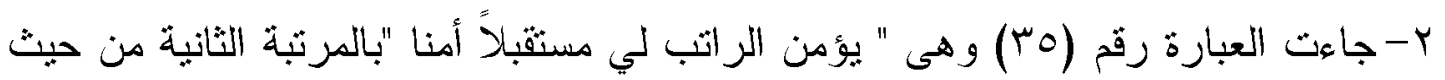

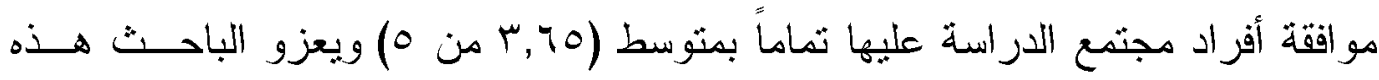

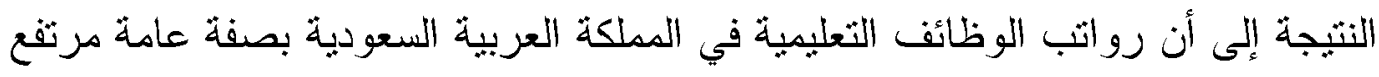

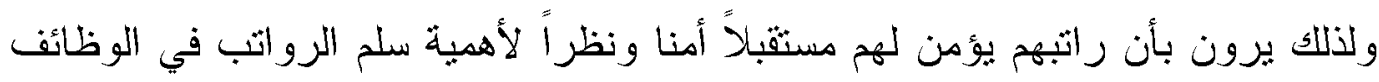

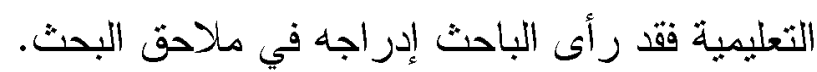

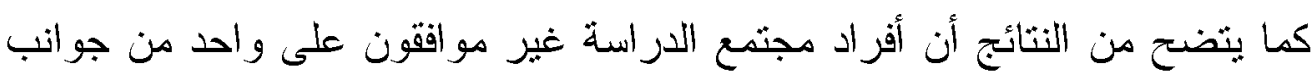

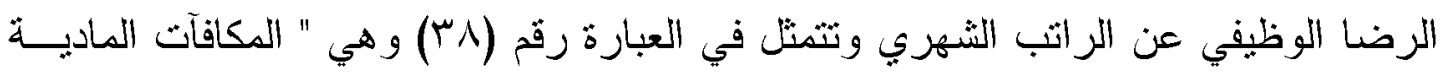

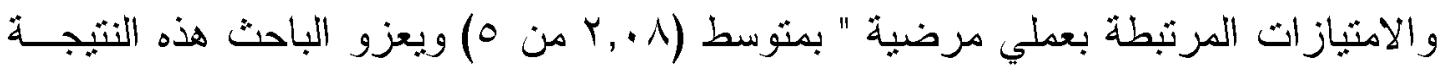

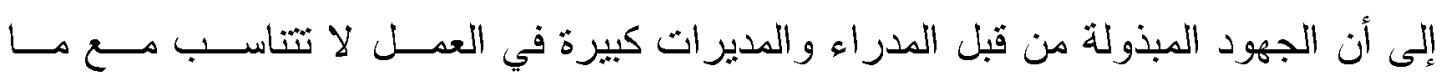

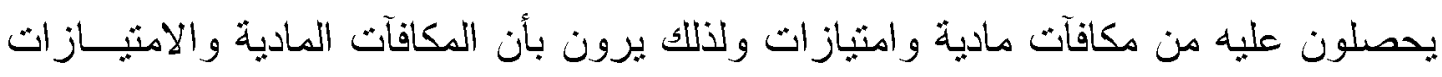

$$
\text { المرنبطة بعملهم غير مرضية. }
$$

\section{1/ الرضا العلاقة مع زملاء العمل:}

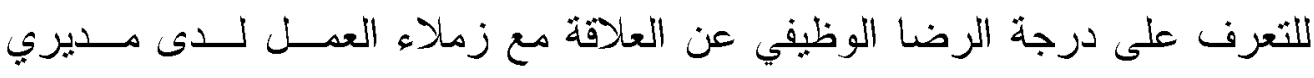

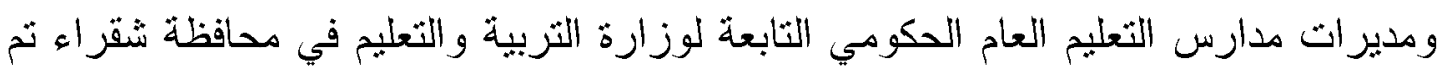

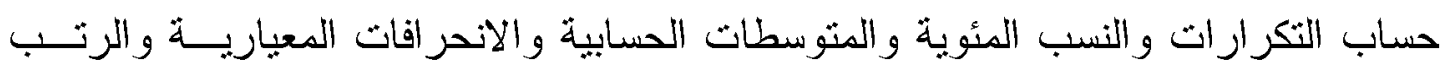
لاستجابات أفراد مجتمع الدراسة على عبارات محور العلاقة مع زملاء العمل وجاءت النتائج

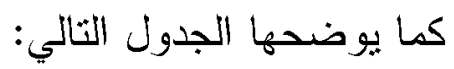




$$
\text { جدول رقمر (19) - (19) }
$$

استجابات أفراد مجتمع الدراسة على عبارات محور العلاقة

مع زملاء العمل مرتبة تنازليا حسب متوسطات المواقتة

\begin{tabular}{|c|c|c|c|c|c|c|c|c|c|c|}
\hline \multirow{2}{*}{ الرتبة } & \multirow{2}{*}{ الانحراف } & \multirow{2}{*}{ المتوسط } & \multicolumn{5}{|c|}{ درجة المواققة } & \multirow{2}{*}{\begin{tabular}{|c|} 
\\
\\
\end{tabular}} & \multirow[b]{2}{*}{ العبـــــــارة } & \multirow{2}{*}{ رقمث } \\
\hline & & & لأواقق & لا أواقق & ل ل إداري & أوافق & تماماً & & & \\
\hline \multirow[b]{2}{*}{1} & \multirow[b]{2}{*}{$\cdot, 79$} & \multirow[b]{2}{*}{, $0 \uparrow$} & - & r & 1 & 19 & $\xi$ & st & \multirow{2}{*}{ 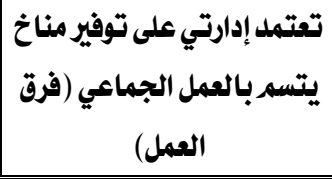 } & \multirow[b]{2}{*}{$\Delta \varepsilon$} \\
\hline & & & - & $r, r$ & 1,7 & $r \cdot, q$ & $7 \xi, 0$ & $\%$ & & \\
\hline \multirow[b]{2}{*}{ r } & \multirow[b]{2}{*}{$\cdot, 70$} & \multirow[b]{2}{*}{$\S, 0}$. & - & 1 & r & rq & ro & st & \multirow{2}{*}{ 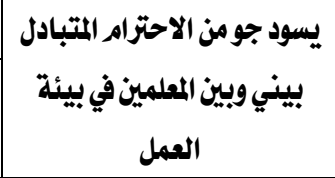 } & \multirow[b]{2}{*}{01} \\
\hline & & & - & 1,7 & $r, r$ & rA,, $\mathrm{r}$ & 07,0 & $\%$ & & \\
\hline \multirow{2}{*}{$r$} & \multirow{2}{*}{$\cdot, A r$} & \multirow{2}{*}{$\xi, \xi Y$} & - & $\varepsilon$ & 1 & rr & ro & st & \multirow{2}{*}{ أتيخُ للمعلمين فرص المشاركة } & \multirow{2}{*}{ or } \\
\hline & & & - & 7,0 & 1,7 & ro,o & 07,0 & $\%$ & & \\
\hline \multirow{2}{*}{$\xi$} & \multirow{2}{*}{$\cdot, \mathrm{Va}$} & \multirow{2}{*}{$\xi, Y Y$} & - & $\varepsilon$ & 1 & r & rq & ك & \multirow{2}{*}{ يتعاون زملائي معي في العمل } & \multirow{2}{*}{ or } \\
\hline & & & - & 7,0 & 1,7 & $0 \cdot, \cdot$ & $\$ 1,9$ & $\%$ & & \\
\hline \multirow{2}{*}{0} & \multirow{2}{*}{$\cdot, \mathrm{v}$} & \multirow{2}{*}{$\varepsilon, 10$} & - & $r$ & $r$ & $\xi$. & iv & 5 & \multirow{2}{*}{ الالتزام بتوجيهاوباتي المعلمون معي في التزبوية } & \multirow{2}{*}{$\xi Y$} \\
\hline & & & - & $\xi, \wedge$ & $r, r$ & $7 \xi, 0$ & $r v, \xi$ & $\%$ & & \\
\hline \multirow{2}{*}{7} & \multirow{2}{*}{$\cdot, V r$} & & - & $r$ & 0 & rA & 17 & st & يقدر الزملاء الجهود التي & \\
\hline & & , & - & $\mathfrak{\xi}, \wedge$ & $\wedge, 1$ & $71, r$ & $r o, \Lambda$ & $\%$ & أبذلها لتحسين العمل & 4 \\
\hline & & & - & 0 & 1 & $\xi$ & 17 & st & أشعر بالرضا عن أداء المعلمين & \\
\hline$r$ &,$n$ & $r, \cdots$ & - & $\wedge, 1$ & 1,7 & $7 \xi, 0$ & ro, 1 & $\%$ & أثناء زيارتي الصفية & $8 n$ \\
\hline & & & 1 & $\checkmark$ & 1 & r. & rr & st & تسهم طبيعة عملي في توطيد & \\
\hline$\wedge$ & $1, \cdots$ & $\boldsymbol{\xi}, \bullet$ & 1,7 & $11, r$ & 1,7 & $\{\Lambda, \xi$ & $r v, 1$ & $\%$ & علاقتي الاجتماعية مع & 0. \\
\hline & $\cdot, 07$ & $\boldsymbol{\xi}, \boldsymbol{Y V}$ & & & & & لعـــا & 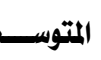 & & \\
\hline
\end{tabular}

من خلال النتائج الموضحة أعلاه يتضح أن أفراد مجتمع الدراسة موافقون نماماً في

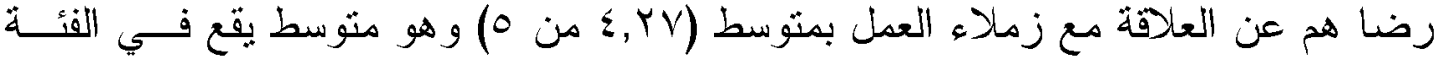

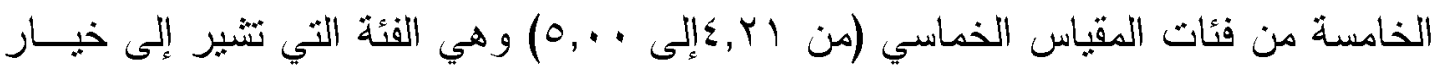
أو اقق تماماً على أداة الدراسة. 


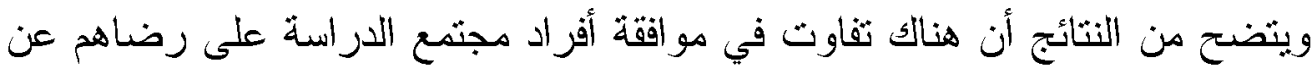

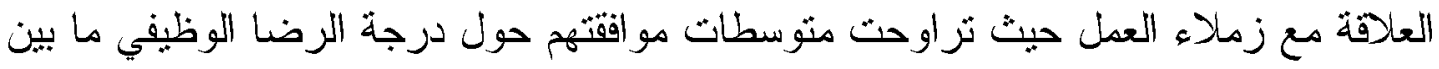

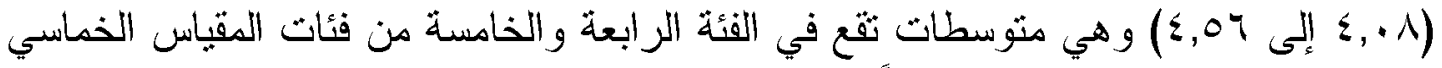

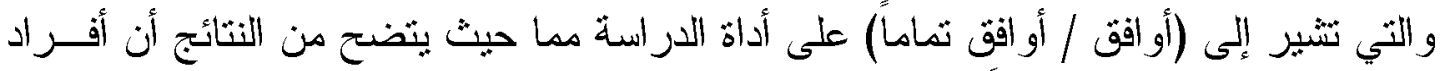

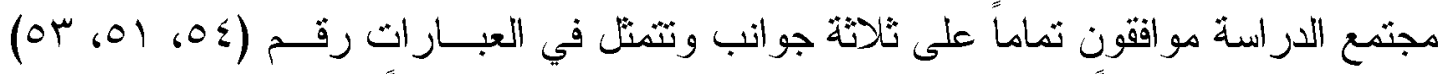

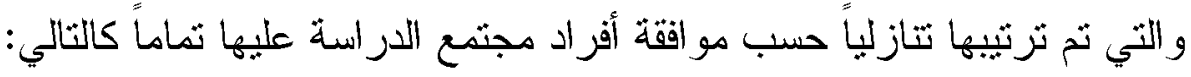

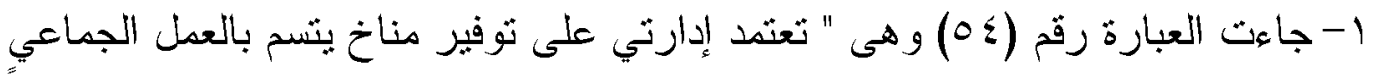

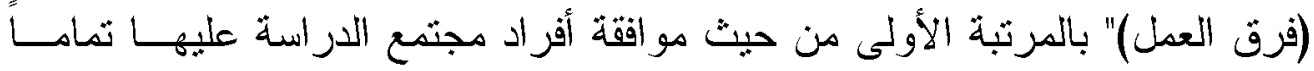

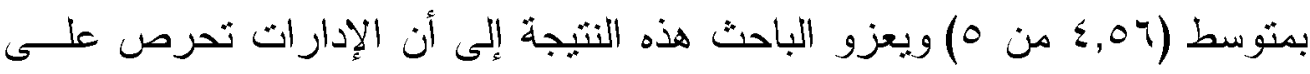

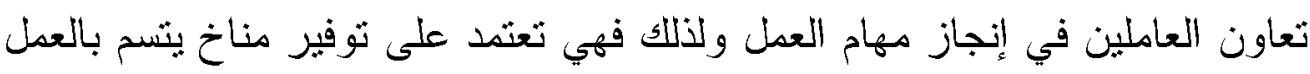
الجماعي (فرق العمل). r-جاءت العبارة رقم (10) وهى العي " بسود جو من الاحثرام المتبادل بيني وبين المعلمين

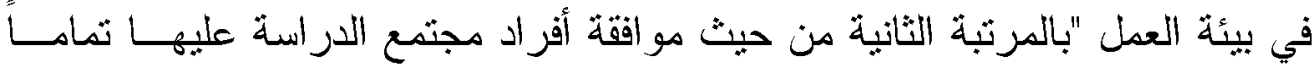

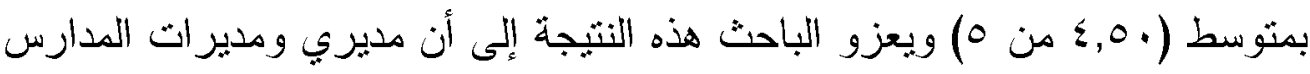

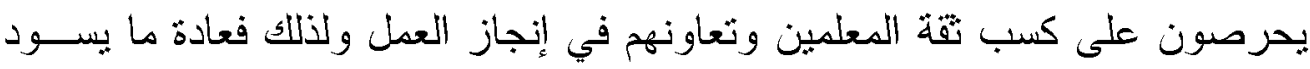

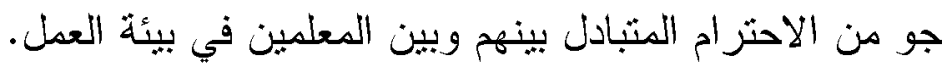

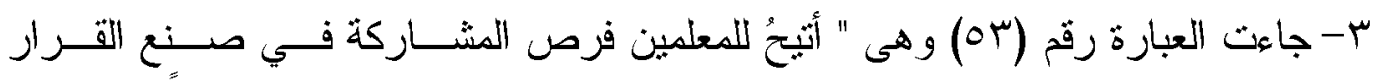

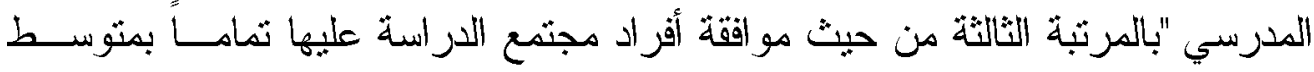

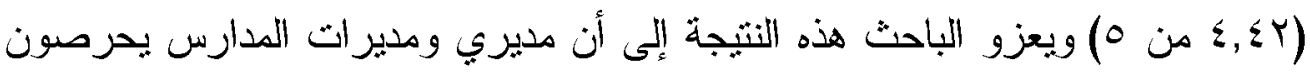

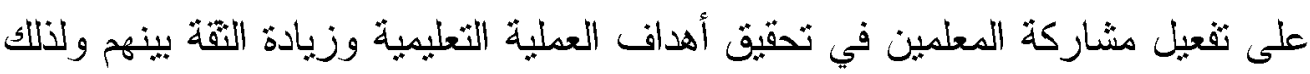

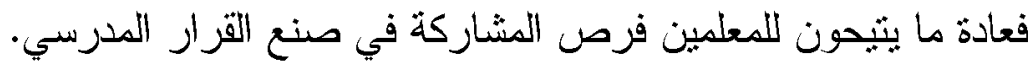

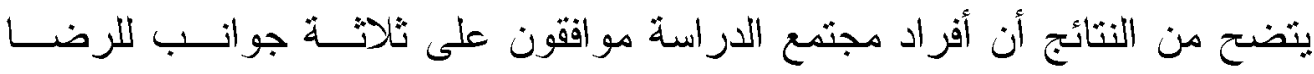

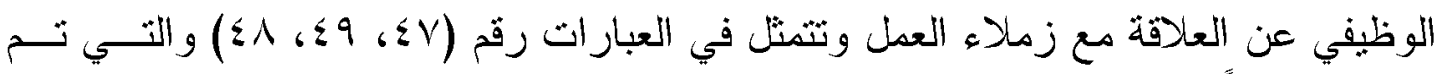

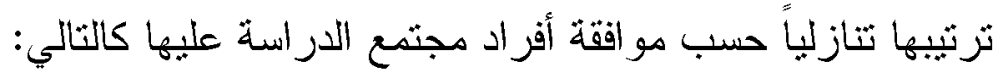

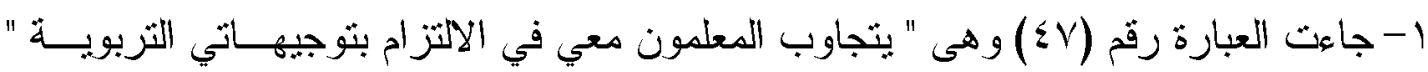

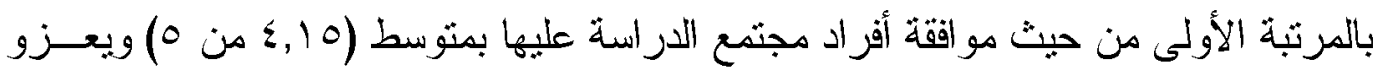

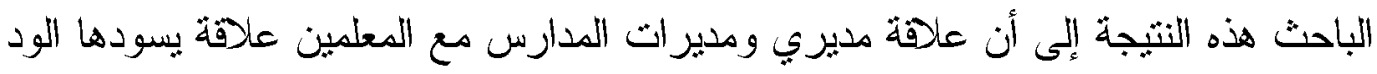

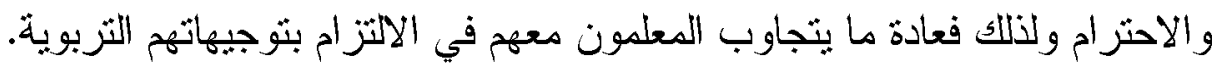

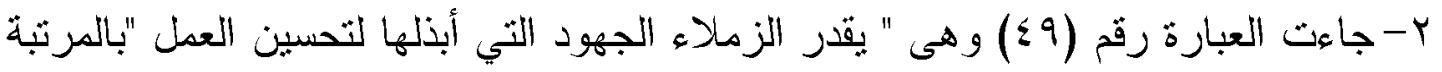

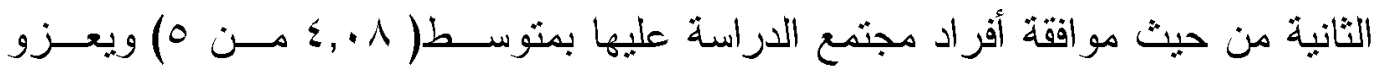

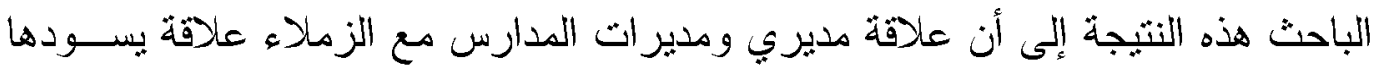


الود والاحترام وغالب المعلمين بدركون الجهود المبذولة من قبل مدير المدرسة لتحسين

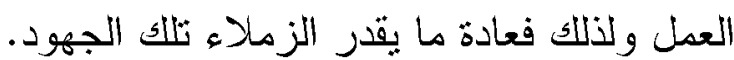

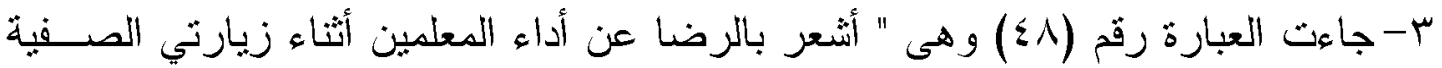

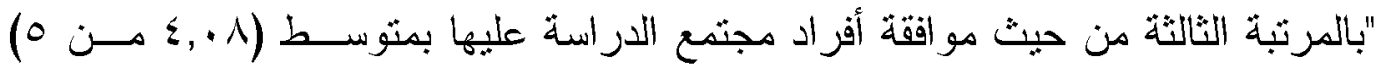

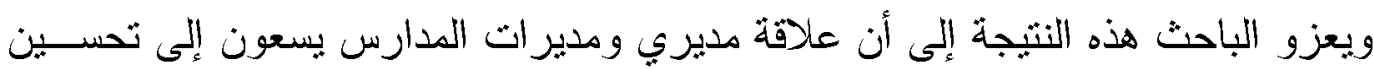

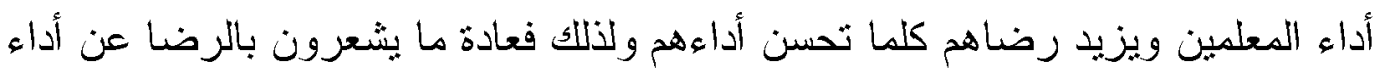
المعلمين أثناء زيارتهم الصفية.

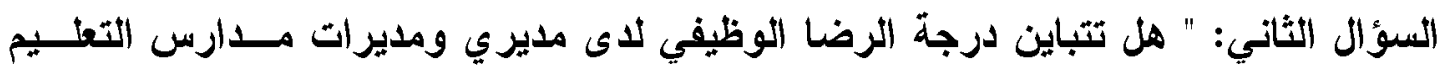

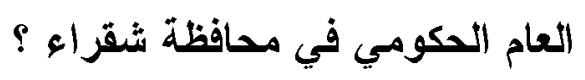

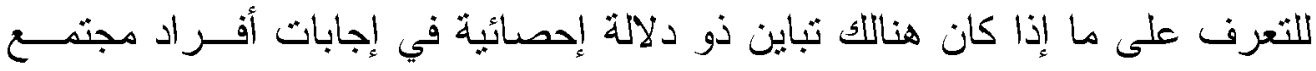

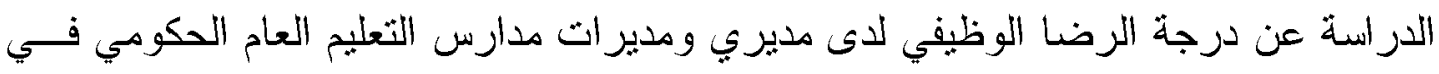

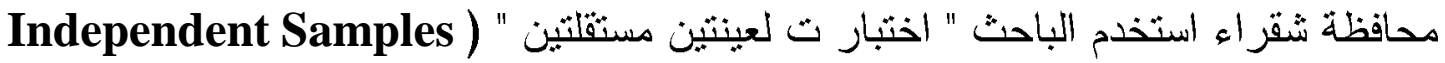

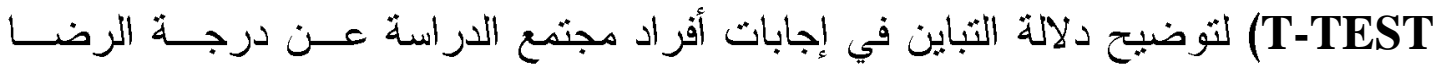

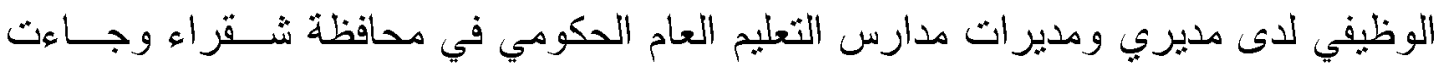
النتائج كما بوضحها الجدول النالي:

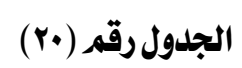

نتائج" اختبارت لعينتين مستقلتين" (Independent Samples T-TEST) للتباين في إجابات أفراد

\begin{tabular}{|c|c|c|c|c|c|c|}
\hline الإحصائية & قيمةت & الالعياري & المتوسط & العلد & 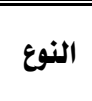 & المحور \\
\hline \multirow{2}{*}{. } & \multirow{2}{*}{ 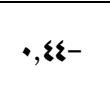 } & oralr. & r,VITI & ro & مديرة & \multirow{2}{*}{ طروف العمل } \\
\hline & & $\xi 1 \leqslant 01$. & 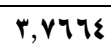 & rv & 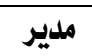 & \\
\hline \multirow{2}{*}{ 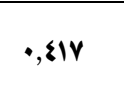 } & \multirow{2}{*}{$\cdot, \wedge 1 \wedge-$} & VEAYO. & $r, 0090$ & ro & مديرة & \multirow{2}{*}{ العلاقة مع إدارة التربية والتعليه } \\
\hline & & $071 \cdot 0$. & $r, v \cdots \varphi$ & $r v$ & مدير & \\
\hline \multirow{2}{*}{ •, TATA } & \multirow{2}{*}{ •,AVA } & N.107. & r, r\&rq & ro & مديرة & \multirow{2}{*}{ النمووالتقلدم الوظيفي } \\
\hline & & VATIY. & $r, 198$. & rv & 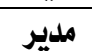 & \\
\hline \multirow{2}{*}{ •, $\cdot \times 1$} & \multirow{2}{*}{$1, \wedge \varepsilon$} & จ9771. & r, १OY\& & ro & مديرة - مل & \multirow{2}{*}{ المكانة الاجتماعية } \\
\hline & & $9 \cdot \wedge 71$. & r, rort & Tr & مدير & \\
\hline \multirow{2}{*}{ •, rvo } & \multirow{2}{*}{ - rAA- } & $9 .+1 \xi$. & $r,|r| \xi$ & ro & مديرة & \multirow{2}{*}{ الراتب الشهري } \\
\hline & & $99+\%$. & $r, 1194$ & rv & 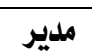 & \\
\hline \multirow{2}{*}{$\cdot, \pi$} & \multirow{2}{*}{$1,+\% \varepsilon$} & oivir. & $\xi$, TYY & ro & مديرة & \multirow{2}{*}{ العلاقة مع زملاء العمل } \\
\hline & & Tirys. & $\xi$, lnor & rv & 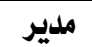 & \\
\hline
\end{tabular}
مجتمع الدراسة عن درجة الرضا الوظيفي لدى مديري ومديرات مدارس التعليم العام الحكومي في محافظة شقراء 
بتضـح من خلال النتائج الموضحة أعلاه عدم وجود ثباين ذو دلالة إحصــائبة عنــد مستوى ه •. · فأقل بين مستويات رضا "المديرين" واتجاهات "المديرات" عن (ظروف العمل, العلاقة مع إدارة الثربية والتعليم, النمو والثقدم الوظيفي, المكانة الاجتماعية, الراثب الثشهري,

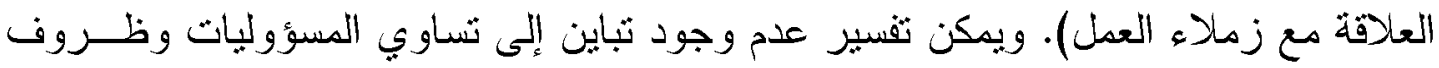
العمل لدى أفر اد الدراسة كذلك اللوائح التعليمية للبنين و البنات مثماثلة. السؤال الثالث: هل تتباين درجة الرضا الوظيفي لاى مديري ومديرات مدارس التعليم التعام الحكومي في محافظة شقراء باختلاف المرحلة التعليمية ؟

للتعرف على ما إذا كاتت هناللك فروق ذات دلالة إحصائية في إجابات أفراد الدراسة

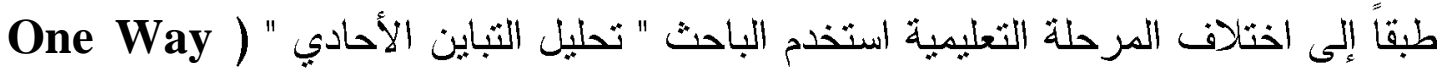

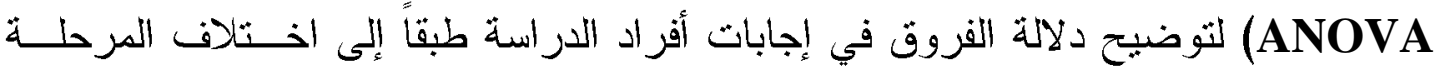
التعليمية وجاءت النتائج كما بوضحها الجدول التالي:

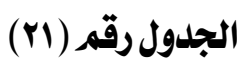

\section{نتائج " تحليل التباين الأحادي "(One Way ANOVA) للفروق في}

إجابات أفراد الدراسة طبقاً إلى اختلاف المرحلة التعليمية

\begin{tabular}{|c|c|c|c|c|c|c|}
\hline 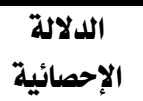 & ق ق قيمة ف & متوسط & الحرجاتة & مربعات & مصلدر التباين & المحور \\
\hline \multirow{3}{*}{ •,rqv } & \multirow{3}{*}{$1, \cdot 9 r$} & •, Yo. & $\varepsilon$ & $1, \cdots$ & بين المجموعات & \multirow{3}{*}{ ظروف العمل } \\
\hline & & $\cdot$, rrA & or & $1 r, 990$ & داخل المجموعات & \\
\hline & & & 71 & 17,997 & المجموع & \\
\hline \multirow{3}{*}{ •, OAr } & \multirow{3}{*}{$\cdot, \times 19$} & • & $\varepsilon$ & 1, IrYr & بين المجموعات & \multirow{3}{*}{ العلاقة مع إدارة التربية والتعليم } \\
\hline & & $\cdot,\{7$. & or & $r q, r+1$ & داخل المجموعات & \\
\hline & & & 71 & rY,orr & المجموع & \\
\hline \multirow{3}{*}{$\cdot, \cdot 9 \varepsilon$} & \multirow{3}{*}{$r, \bullet A r$} & I,YYY & 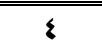 & $\xi, 9 \cdot 0$ & بين المجموعات & \multirow{3}{*}{ النمووالتقدم الوظيفي } \\
\hline & & $\cdot, 0 \wedge \Lambda$ & or & rr,\&qY & داخل المجموعات & \\
\hline & & & 71 & $r \wedge, \xi \cdot r$ & المجموع & \\
\hline \multirow{3}{*}{ •, ๆะะ } & \multirow{3}{*}{$\cdot, 7 r q$} & $\cdot,\{\wedge \uparrow$ & 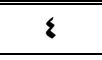 & $1,9 r r$ & بين المجموعات & \multirow{3}{*}{ المكانة الاجتماعية } \\
\hline & & •,マฯร & or & $\{r, 0 \leqslant \wedge$ & داخل المجموعات & \\
\hline & & & 71 & $\{0,\{n$ & المجموع & \\
\hline \multirow{3}{*}{$\cdot, 071$} & \multirow{3}{*}{$\cdot, r \leqslant r$} & $\cdot,\urcorner \xi \cdot$ & 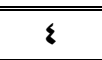 & $r, 009$ & بين المجموعات & \multirow{3}{*}{ الراتب الشهري } \\
\hline & & $\cdot, \wedge 7 r$ & or & $\{9,17 \xi$ & داخل المجموعات & \\
\hline & & & 71 & O1,YrY & المجموع & \\
\hline \multirow{3}{*}{$\cdot, 9+0$} & \multirow{3}{*}{$\cdot$, roo } & $\cdot, \bullet \wedge \varepsilon$ & $\varepsilon$ & rrv. & بين المجموعات & \multirow{3}{*}{ العلاقة مع زملاء العمل } \\
\hline & & •,rrI & or & $11, \wedge \leqslant 0$ & داخل المجموعات & \\
\hline & & & 71 & $19,1 \mathrm{Ar}$ & المجموع & \\
\hline
\end{tabular}




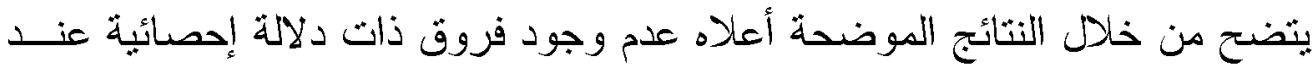

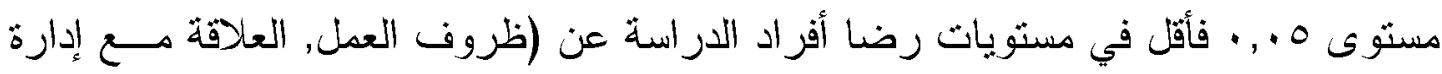

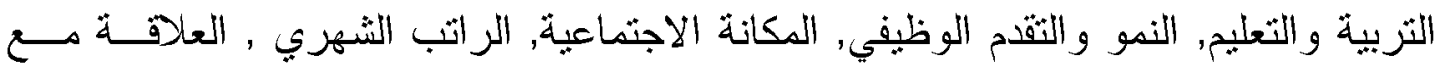
زملاء العمل) باختلاف متغير المرحلة التحليمية.

\section{نتائسهـ الدراسيسة:}

\section{أولاً: النتائج المتعلقة بوصف أفراد الدراسة:}

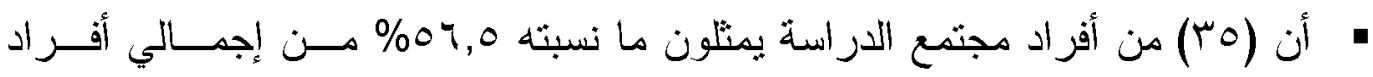
مجتمع الدراسة إناث وهم الفئة الأكثر من أفراد مجنمع الدراسة.

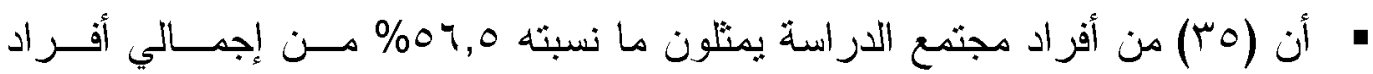

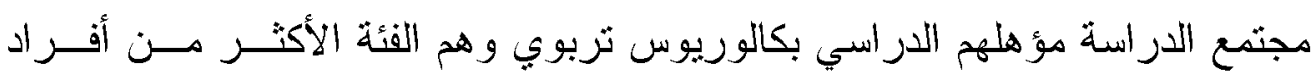
مجتمع الدراسة.

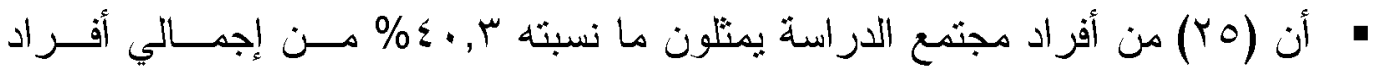

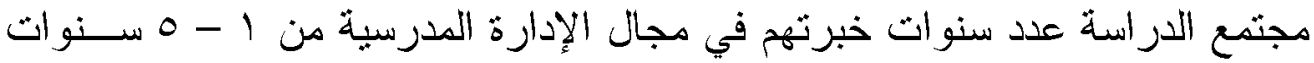
و هم الفئة الأكتر من أفراد مجتمع الأراسة.

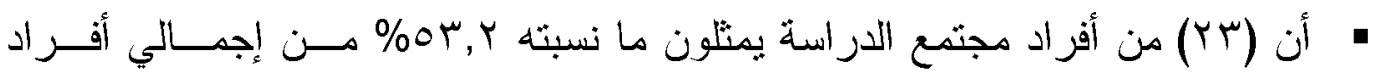

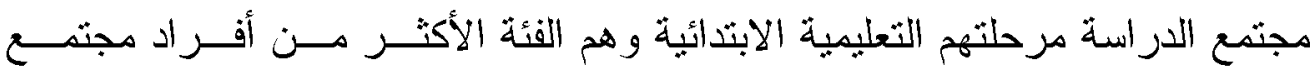
الدر اسة.

\section{ثانياً: النتائج المتعلقة بأسئلة الدراسة :} السؤال الأول: ما درجة الرضا الوظيفي لاى مديري ومديرات مدارس التعليم العام الحكومي

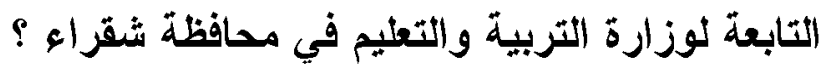

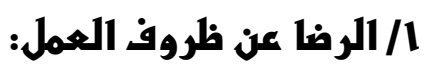
• أفر اد مجتمع الدراسة مو افقون على عن ظروف العمل العمل.

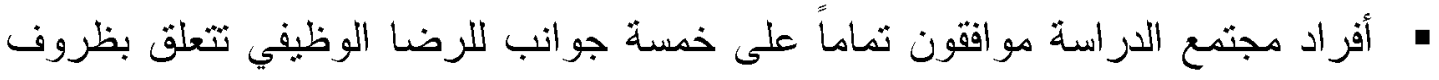

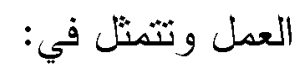

1. أثنعر بالسعادة أثثاء تأدية عملي. r. كترة الدوام كافية لإنجاز عطلي. 
ع. طييعة العمل نثتاسب مع قدراتي الثخصبة.

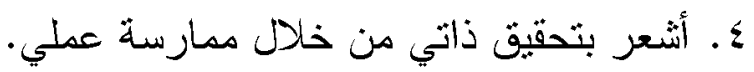
0. تناسبني ساعات الدوام الثي بنطلبها عملي.

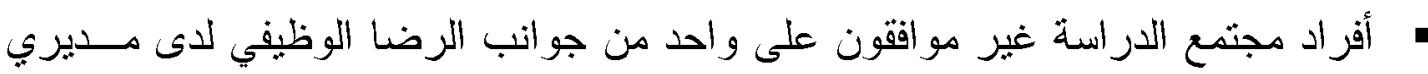
ومديرات مدارس التعليم العام الحكومي التابعة لوزارة التربية و التعليم في محافظة شُقراء عن ظروف العمل وتثمثل في "تثوفر لاي المنطلبات المادية اللخزمة في العمل".

\section{|r/ الرضا عن العلاقة مع إدارة التربية والتعليم:}

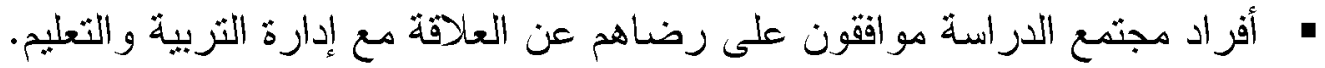

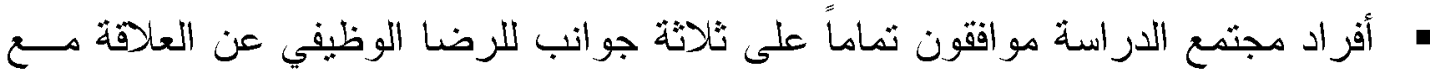
إدارة الثربية و التعليم وتثنثل في:

ا.تربطني بالمسؤولين في إدارة النربية والتعليم علاقة احترام منبادل.

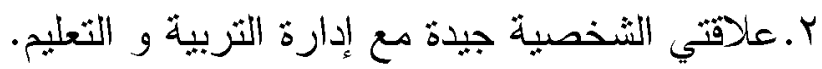
r.بيتحامل الإنشراف التربوي معي بنقة لتحقيق مهام وظيفتي.

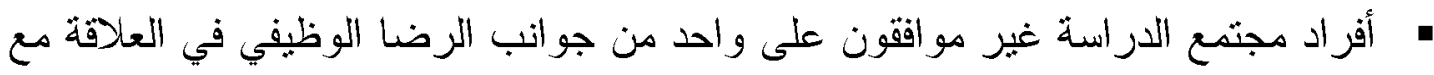

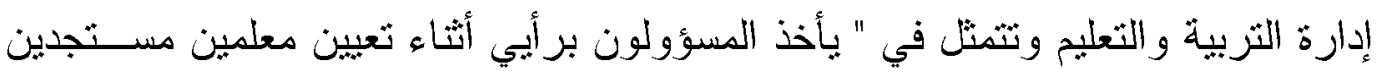
في مدرستي ".

\section{" / / الرضا عز النمو والنقدم الوظيفي:}

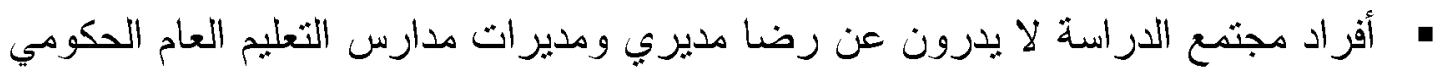

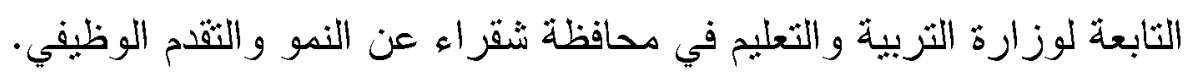

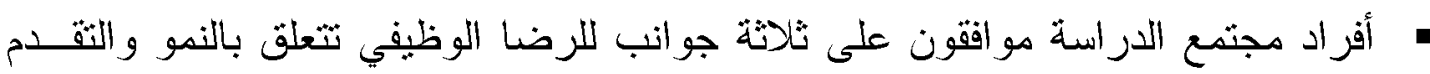

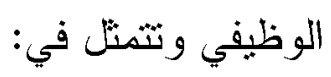
1. ال فرص التدريب و التعليم مناحة لي أنثاء الخدمة. r. الفرص متاحة لي لنتمية مهار اتي في العمل.

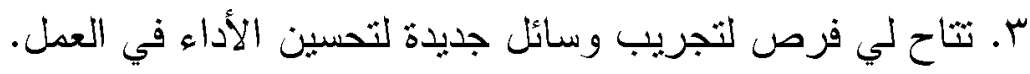

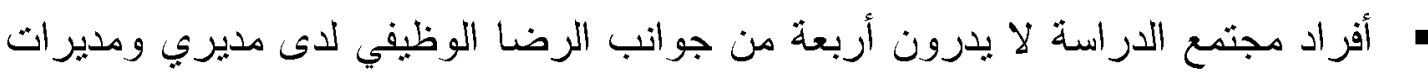

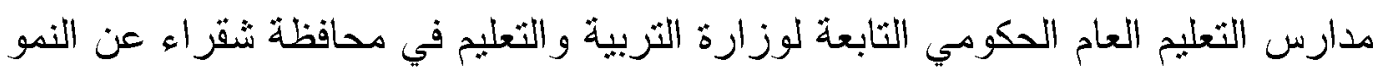

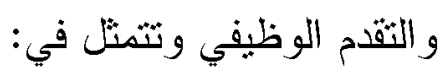


1. الحو افز المعنوية متاحة لي في وظيفتي من خلال التدريب والتعليم أثناء الخدمة. r. تثم الثرقية في مجال عملي وفقا لمعايير محددة. r. الترقية في مجال عملي مناحة لمن يسنحقها.

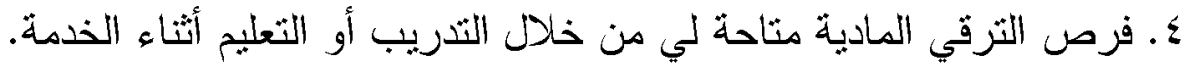

\section{ع/ الرضا عز المكانة الاجتما عية:}

• أفراد مجتمع الدراسة مو افقون على عن المكانة الاجنماعبة.

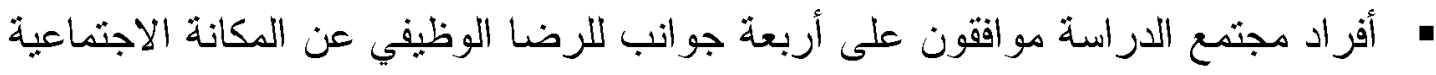
وتثمثل في: - ونيع

$$
\text { 1- ب- يبدي المجتمع مهنتي الحالية لأسرتي سمعة اجنماعية طيبة. }
$$

r- إن الأصدقاء من ذوي المهن الأخرى يُشُعرونك بالاحترام بفعل مهنتك. ؟ - أنثعر أن وظيفتي حققت لي المكانة الاجتماعبة الني أطمح إليها.

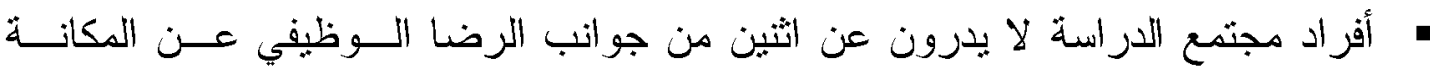

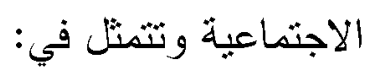

1- يتيح لي عملي فرصة التعرف على شخصيات مرموقة وتكوين الصداقات. r- أشعر أن وظبفتي تعطي مكانة اجتماعبة أعلى من الوظائف الأخرى.

\section{/ الرضا عز الراتب الشهري:}

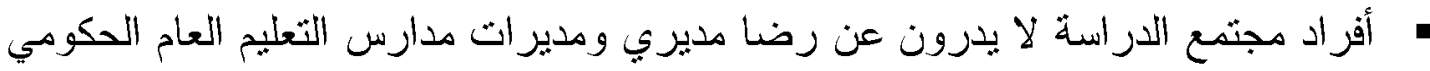

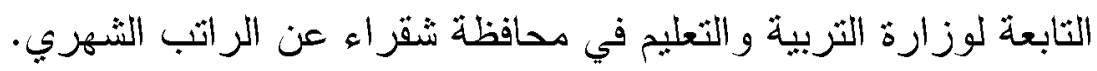

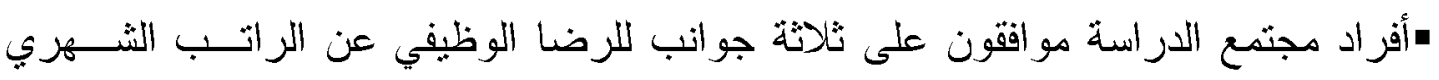
وتثمثل في:

$$
\begin{aligned}
& \text { 1- يغطي راتبي الاحتباجات الأساسية. } \\
& \text { r- بؤهن الر اتب لي مستقبلاً أمنا. } \\
& \text { ب- بيتاسب راتبي مع خبر اتي ومؤ هلاتي العلمية. }
\end{aligned}
$$

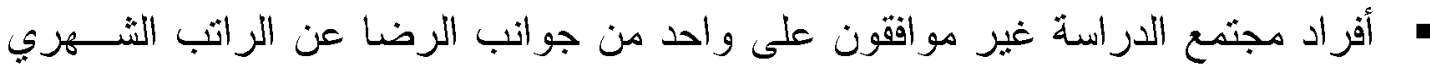

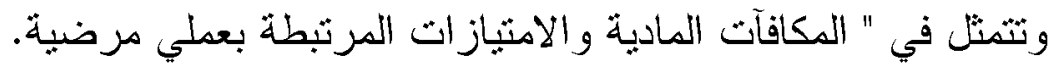




\section{1/1/الرضا عن العلاقة مع زملاء العمل :}

• أفر اد مجتمع الدراسة مواقفون ثماماً عن رضا مديري ومدير ات مدارس التعلـيم العــام الحكومي التابعة لوزارة التربية والتعليم في محافظة شقراء عن العلاقة مع زملاء العدل.

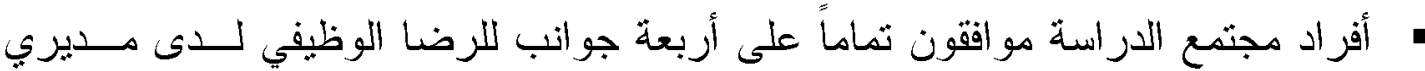
ومديرات مدارس التعليم العام الحكومي التابعة لوزارة الثريية والتعليم في محافظة شقراء

$$
\text { عن العلاقة مع زملاء العمل وتثمنل في: }
$$

1- تعتمد إدارني على نوفير مناخ يتسم بالعمل الجماعي (فرق العمل). Y- يسود جو من الاحترام المتبادل بيني وبين المعلمين في بيئة العدل.

ب- أتبحُ للمعلمين فرص المشاركة في صنع القرار المدرسي.

$$
\text { ـ - يتعاون زملائي معي في العمل. }
$$

• أفراد مجتمع الدراسة موافقون على أربعة جوانب للرضا الوظيفي عن العلاقة مع زملاء

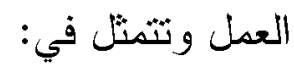

1- يتجاوب المعلمون معي في الالتزام بتوجيهاتي التربوية.

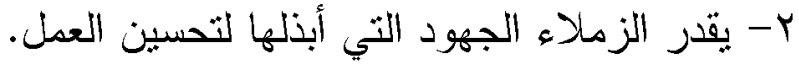
r- أثعر بالرضا عن أداء المعلمين أثتاء زيارني الصفية. ع - تسهم طبيعة عملي في توطيد علاقتي الاجتماعية مع المعلمين. السؤال الثثاني: هل تتباين درجة الرضا الوظيفي لاى مديري ومديرات مدارس التعليم التعام

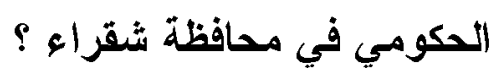

لا يوجد تباين ذو دلالة إحصائية عند مستوى 0 ., ، فأقل بين مستويات رضــا "المديرين" واتجاهات "المديرات" عن (ظروف العمل, العلاقة مع إدارة الثربية و التعليم, النمو و الثقدم الوظيفي, المكانة الاجثماعية, الراتب الثهري , العلاقة مع زملاء العمل). السؤال الثثاث: هل تتباين درجة الرضا الوظيفي لاى مديري ومديرات مدارس التعليم التعام الحكومي في محافظة شثراء باختلاف المرحلة التعليمبة ؟ لايوجد فروق ذات دلالة إحصائية عند مستوى ه., · فأقل في مسثويات رضا أفراد الدراسة عن (ظروف العمل, العلاقة مع إدارة التربية و التعليم, النمو والثقدم الوظيفي, المكانة الاجنماعبة, الر اتب الثهري , العلاقة مع زملاء العمل) باختلاف متغير المرحلة التعليمبة. 


\section{توصيـــات الدراســـة:}

ا. العمل على تعزيز مستوى الرضـا الوظيفي الحالي لدى مديري ومديرات مدارس التعلــيم العام الحكومي التابعة لإدارة التعليم في محافظة شُقر اءو. Y.نوفير الحوافز التتجيعية الثي تعزز من الرضـا الوظبفي وفق معايير محددة بحيث نكـــون عادلة وو اضحة للجميع. r. العمل على زيادة فرص التدريب و التأهيل لمديري ومديرات المدارس دهــــــهم فــي تطوير ممارساتهم العملية واكتساب الخبرات والتي بدور ها تتعكس على العملية التعليميــة برمنها.

ع. ثطوير النظام المالي للكادر التعليمي المطبق حالياً بحيث بمنح مدير ومــديرة المدرســة حقوقاً أكثر و امنباز ات أفضل. 0. أخذ رأي مديري ومديرات المدارس أثناء تعيين معلمين جدد لدى المدرسة. T.وضع وزارة الثربية والثعليم خطة إعلامية تهدف إلى رفع مكانة مدير ومديرة المدرســة

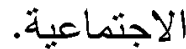




\section{السمراجــــ}

$$
\begin{aligned}
& \text { 1- القر آن الكربم. } \\
& \text { r- الأحاديث الثربفة. }
\end{aligned}
$$

r- أسعد، محدد حسن علي، ورسلان، نبيل إسماعيل. الرضا الوظيفي للقوى البثربة العاملة في المملكة العربية السعودية. كلية الاقتصاد والإدارة، جامعة الملك عبدالعزيز، مطـابع

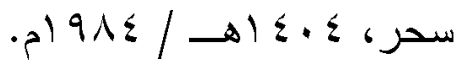

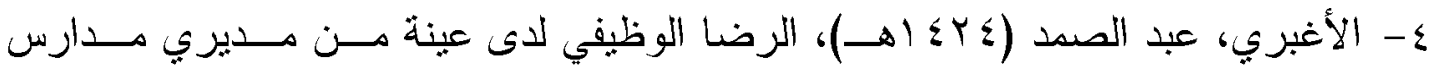
التعليم العام الحكومي بالمحافظة الثرقية في المملكة العربية السعودية، مجلة دراســات

$$
\text { الخليج و الجزيرة العربية، العدد } 9 \text { ـ 1، الكويت، جامعة الكويت. }
$$

ه- أنيس، إبر اهيم و آخرون، (Yو (اهـ)، المعجم الوسبط، الطبعة الثانية، بدون ناشر • ج- البابطين، عبدالوهاب (.99 19) المتغيرات المرثنطة بمستوى الرضا الوظيفي لدى معلمي المرحلة الثانوية المطورة في محافظة الرياض رسالة ماجستير غير منشورة، الرياض، جامعة الملك سعود، كلية الثربية. - الحاج، فايز محمد علي. الرضـا المهـني للمعلم في التعليم في المملكة. مؤتــمر المعلم

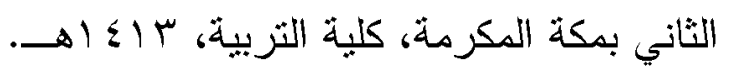
ه- سليمان، مهدي كامل أحمد. معوقات في الإدارة المدرسبة مــن وجهـة نظــر مـديري ومديرات المدارس الأساسية والثانوية الحكومية في محافظتي نابلس وطولكرم. رسـالة ماجستير غير منشورة. جامعة النجاح الوطنية، فلسطين، 999 (م. 9- سبز لاقي، أندرو دي، ووالاس، مارك جي. السلوك التنظيمي والأداء. ترجمــة: جعفــر أبو القاسم أحمد، الرياض: معهد الإدارة العامة، بإئ اهـ / 199 (م. • ا- الشابـــي، طلال أحمد حمود. الرضـا الوظيفي لـدى شــــاغلي الوظـــائف التعليميــة بـمدارس التعليم العام الحكومي الثانوي للبنين الحكومية والأهلية بـمحافظة جـدة در اسة ميدانية مقارنة -. رسالة ماجستير غير منشــورة، جامعسـة أم القــرى، مكــة

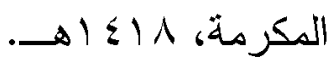


11- الصُُماني، خالد بن عبيد. العلاقة بين الرضا الوظيفي ووجهة العزو لدى عينة سعودية

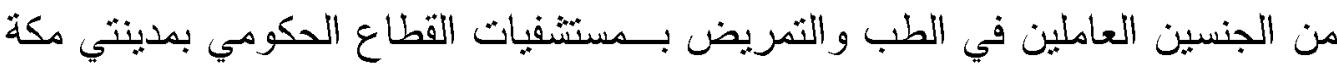

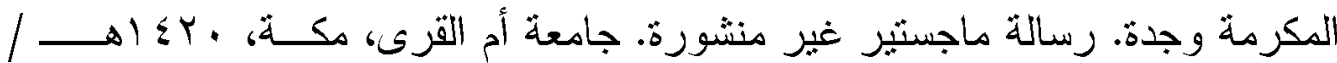
.01999 r ا- عاشور، أحمد صقر • إدارة القوى العاملة: الأسس السلوكية وأدوات البحث التطبيةـي.

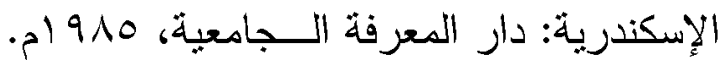

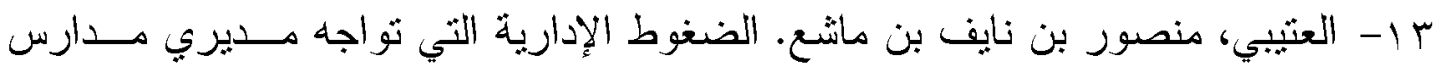
التعليم العام الحكومي و تأثير ها على أدائهم من وجهة نظرهم بدحافظة مكة المكرمسـة.

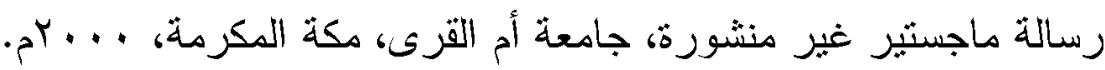
ع ا- العديلي، ناصر محمد. الدو افع والحوافز و الرضا الوظيفي في الأجهزة الحكومية فــي

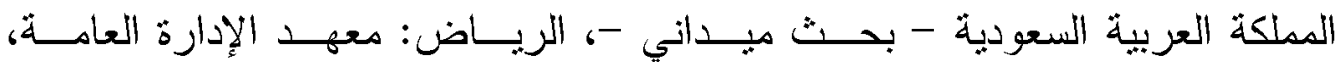

$$
\text { . } 9 \lambda r / \rightarrow 1 \varepsilon \cdot r
$$

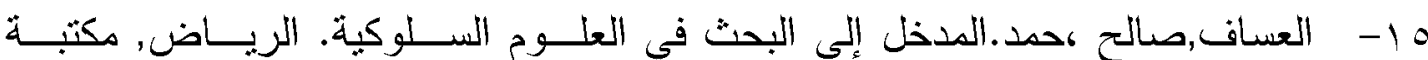

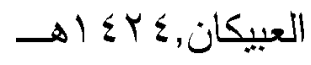

7 ا - العقرباوي، سالم، مستوى ومصادر الاحتراق النفسي لدى مديري المــدارس الثانويـــة

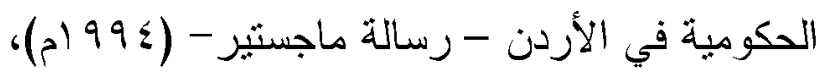

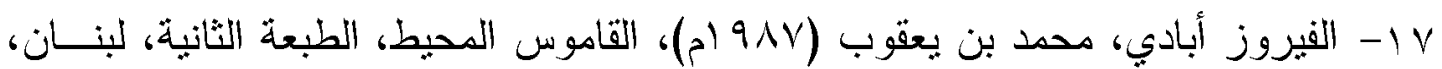

$$
\text { بيروت، مؤسسة الرسالة. }
$$

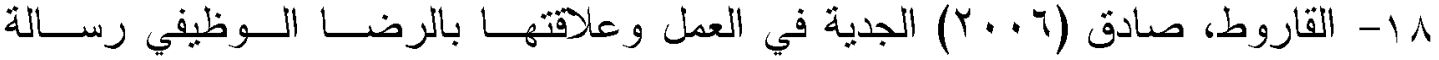

$$
\text { ماجستير · }
$$

9 1- محمد، انثر اح كمال محمد. الرضـا الوظيفي للمر أة العاملة فــي المــارس الثانويــة

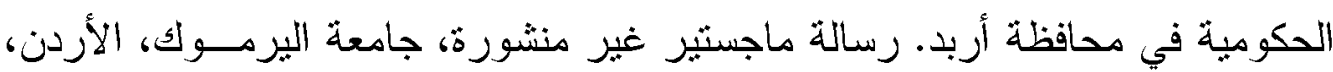
.01994

• ץ- محمود، كمال خليل يونس. الصعوبات الثي تواجه مديري المدارس الأساسية الحكومبة

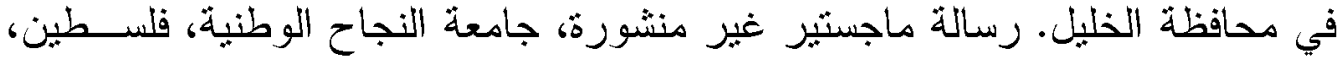




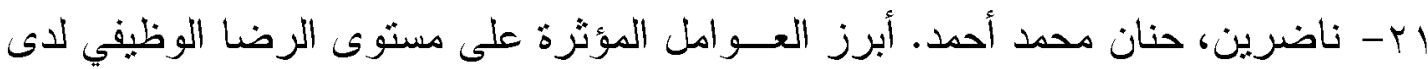

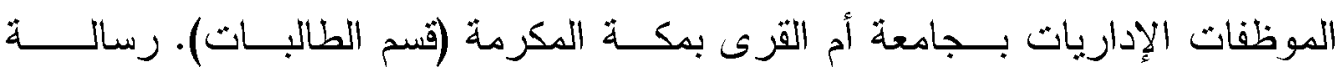

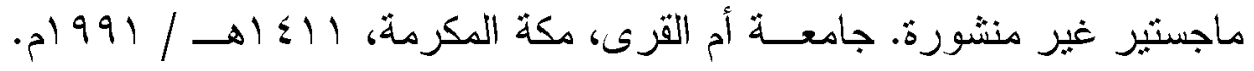
r r- النجار، نبيل الحسيني، وراغب، مدحت مصطفى. إدارة الأفراد و العلاقات الإنسـانية.

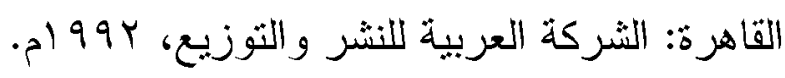

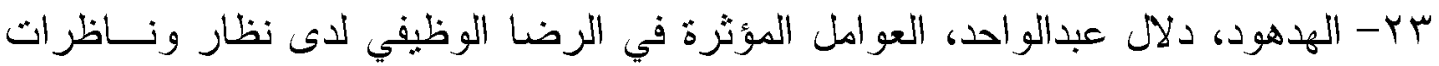

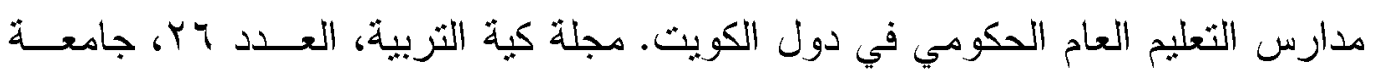

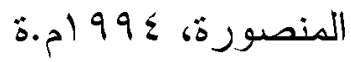

